\title{
Hydrogen Demand, Production, and Cost by Region to 2050
}

prepared by

Center for Transportation Research

Energy Systems Division

Argonne National Laboratory

and

TA Engineering, Inc.

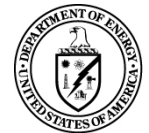




\section{About Argonne National Laboratory}

Argonne is managed by The University of Chicago for the U.S. Department of Energy under contract W-31-109-Eng-38. The Laboratory's main facility is outside Chicago, at 9700 South Cass Avenue, Argonne, Illinois 60439. For information about Argonne and its pioneering science and technology programs, see www.anl.gov.

\section{Availability of This Report}

This report is available, at no cost, at http://www.osti.gov/bridge. It is also available on paper to U.S. Department of Energy and its contractors, for a processing fee, from:

U.S. Department of Energy

Office of Scientific and Technical Information

P.O. Box 62

Oak Ridge, TN 37831-0062

phone (865) 576-8401

fax (865) 576-5728

reports@adonis.osti.gov

\section{Disclaimer}

This report was prepared as an account of work sponsored by an agency of the United States Government. Neither the United States Government nor any agency thereof, nor The University of Chicago, nor any of their employees or officers, makes any warranty, express or implied, or assumes any legal liability or responsibility for the accuracy, completeness, or usefulness of any information, apparatus, product, or process disclosed, or represents that its use would not infringe privately owned rights. Reference herein to any specific commercial product, process, or service by trade name, trademark, manufacturer, or otherwise, does not necessarily constitute or imply its endorsement, recommendation, or favoring by the United States Government or any agency thereof. The views and opinions of document authors expressed herein do not necessarily state or reflect those of the United States Government or any agency thereof, Argonne National Laboratory, or The University of Chicago. 


\section{Hydrogen Demand, Production, and Cost by Region to 2050}

by

Margaret Singh

Center for Transportation Research, Energy Systems Division, Argonne National Laboratory

Jim Moore and William Shadis

TA Engineering, Inc.

for

Phil Patterson

U.S. Department of Energy (EERE/PBA)

August 3,2005 



\section{CONTENTS}

ACKNOWLEDGMENTS

viii

SUMMARY

ix

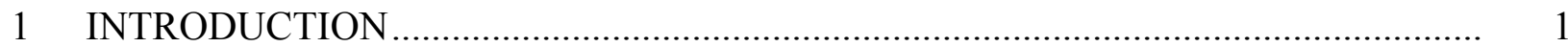

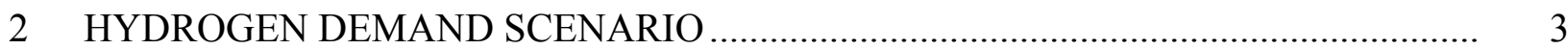

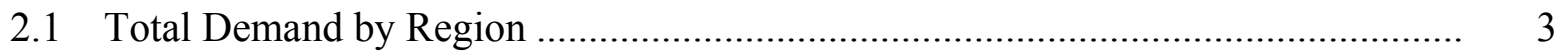

2.2 Within-Region Demand ........................................................................ 3

$3 \quad$ HYDROGEN PRODUCTION ............................................................................ 11

3.1 Overview of Key Assumptions Used in Estimating the Resources

Used to Produce Hydrogen............................................................................. 11

3.2 Resources Used in $\mathrm{H}_{2}$ Production ............................................................... 12

3.3 Share of $\mathrm{H}_{2}$ Generated by Distributed Production by Resource Fuel ................... 14

3.4 Centralized Production of $\mathrm{H}_{2}$ by Resource Fuel and Region ............................ 21

3.5 Final $\mathrm{H}_{2}$ Production Estimates by Region for the GYOW Scenario ...................... 23

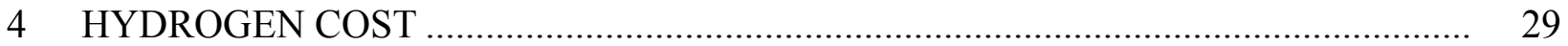

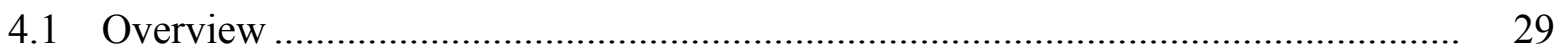

4.2 Centralized Hydrogen Production Cost Estimates .............................................. 31

4.2.1 Production Technology .................................................................... 31

4.2.2 Delivery and Dispensing Costs: National Averages ............................... 32

4.2.3 Regional Delivery Costs: Pipelines ....................................................... 34

4.2.4 Regional Delivery Costs: Other ......................................................... 36

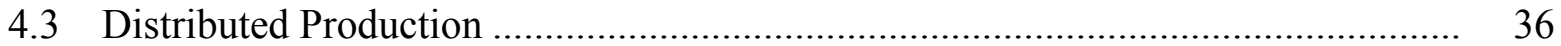

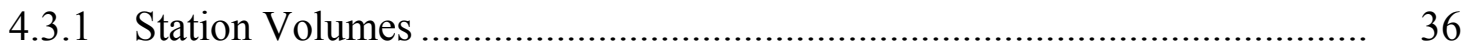

4.3.2 Station Cost Analysis ........................................................................ 38

4.4 Observations on $\mathrm{H}_{2}$ Production Cost Estimates ............................................. 39

4.5 Final Delivered $\mathrm{H}_{2}$ Cost Estimates for the GYOW Scenario ............................... 39

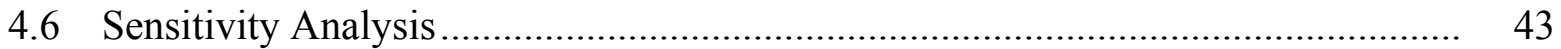

5 ALTERNATIVE SCENARIOS IN REGIONAL H HODEL ................................. 51

6 ISSUES REQUIRING FURTHER ANALYSIS .................................................... 53

6.1 Issues Related to Estimates of $\mathrm{H}_{2}$ Production from Various Resource Fuels ......... 53

6.1.1 Resource Potential of $\mathrm{H}_{2}$ Resource Fuels ......................................... 53

6.1.2 Development of Regional $\mathrm{H}_{2}$ Supply Curves......................................... 53

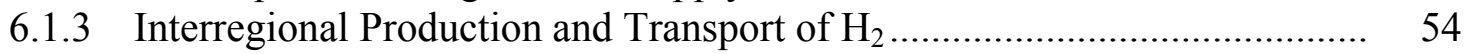




\section{CONTENTS (CONT.)}

6.2 Issues Related to $\mathrm{H}_{2}$ Demand, Especially in Non-Metropolitan Areas, and the Refueling Facilities that Need to be Established to Serve that Demand ........... 54

6.2.1 Rural Travel Requirements ............................................................ 54

6.2.2 Nature of Rural Interstate Travel.......................................................... 54

6.2.3 Potential Changes in Rural or Non-Metropolitan Travel .......................... 54

6.2.4 Magnitude of FCV Refueling Infrastructure in Non-Metropolitan Areas...................................................................... 55

6.2.5 Number of Gasoline-Refueling Facilities.............................................. 55

6.2.6 Status of Non-Metropolitan Interstate Refueling Locations ..................... 55

6.2.7 Travel Distances to Refuel .................................................................... 56

6.2.8 Distributed Production in Non-Metropolitan Areas in Low-H $H_{2}$-Demand Scenarios.............................................................. 56

6.2.9 Alternative Assumptions for Provision of $\mathrm{H}_{2}$ to Non-Metropolitan Areas.......................................................................... 56

6.2.10 Reasonable Upper Bound on Distributed Production ............................... 57

6.3 Issues Related in Particular to the Early Years of FCV Market Penetration .......... 57

6.3.1 Phase-In of FCVs by U.S. Census Division .......................................... 57

6.3.2 Distributed $\mathrm{H}_{2}$ Production in Metropolitan Areas ................................... 57

6.4 Issues Related to $\mathrm{H}_{2}$ Pathway Cost Estimates ............................................ 58

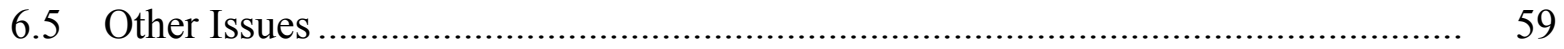

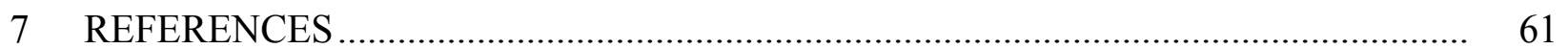

APPENDIX A: COST ESTIMATES BY RESOURCE FUEL INPUT

TO REGIONAL $\mathrm{H}_{2}$ MODEL ....................................................... 65

APPENDIX B: ALTERNATIVE ESTIMATES OF THE COST OF DISTRIBUTED PRODUCTION OF HYDROGEN FROM ELECTROLYSIS ................... 83

APPENDIX C: KEY ASSUMPTIONS IN REGIONAL H HODEL 1.0 ....................... 85

\section{TABLES}

2.1 Details of Three Hydrogen Demand Scenarios ...................................................

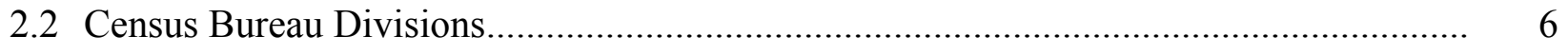

2.3 Total GYOW Demand and Production in 2050 by U.S. Region .............................. 7

2.4 Non-Metropolitan LV Travel and Assumed FCV Travel and Demand ......................... 9 


\section{TABLES (CONT.)}

3.1 Regional $\mathrm{H}_{2}$ Resource Fuel Characterizations ……......................................................... 15

3.2 Maximum $\mathrm{H}_{2}$ That Can Be Generated for Centralized Electrolysis ............................... 20

3.3 Distributed Production Share of Total $\mathrm{H}_{2}$ Production by Region...................................... 20

3.4 Natural Gas Share of Distributed $\mathrm{H}_{2}$ Production....................................................... 21

3.5 Percent of $\mathrm{H}_{2}$ Produced Centrally from Natural Gas where National Demand for $\mathrm{H}_{2}>0.5$ Quads in Any Year ............................................................................. 22

3.6 Coal and Renewables Shares once Natural Gas and Nuclear Shares

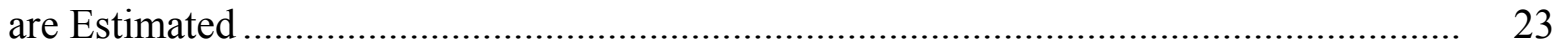

3.7 Biomass, Wind, and Solar Shares of Renewables .............................................................. 24

3.8 Final Estimate of $\mathrm{H}_{2}$ Production in the United States for GYOW Scenario ..................... 24

3.9 Source of $\mathrm{H}_{2}$ in GYOW Scenario by Region.............................................................. 25

4.1 Costs of Input Energy to Produce Hydrogen, National Averages ..................................... 30

4.2 Costs of Input Energy to Produce Hydrogen ................................................................. $\quad 30$

4.3 Process Characteristics Summary ……………....................................................... 33

$4.4 \mathrm{H}_{2}$ Delivery and Dispensing Costs .......................................................................... 34

4.5 Summary of Oil and Gas Journal Pipeline Right-of-Way Cost Investigations................ 35

4.6 Number of Non-Metropolitan Area Stations Producing $\mathrm{H}_{2}$ at the Station and Volume/Month in the GYOW Scenario ...................................................................... 37

4.7 Final Delivered $\mathrm{H}_{2}$ Costs in GYOW by Region by Production Technology .................... 40

4.8 Final Delivered $\mathrm{H}_{2}$ Costs in GYOW: U.S. Summary by $\mathrm{H}_{2}$

Production Technology

4.9 Final Delivered $\mathrm{H}_{2}$ Costs in GYOW by Region by Metropolitan and Non-Metropolitan Areas 


\section{TABLES (CONT.)}

4.10 Sensitivity Cases Altering Distributed Production Assumptions of GYOW:

U.S. Average $\mathrm{H}_{2}$ Cost

4.11 Sensitivity Cases Altering Distributed Production Assumptions of GYOW: Average U.S. Metropolitan and Non-Metropolitan $\mathrm{H}_{2}$ Cost .....

A.1 Centralized Production, Delivery, and Dispensing of $\mathrm{H}_{2}$ Using Natural Gas

A.2 Centralized Production, Delivery, and Dispensing of $\mathrm{H}_{2}$ Using Coal with

Carbon Sequestration.

A.3 Centralized Production, Delivery, and Dispensing of $\mathrm{H}_{2}$ Using Biomass.

A.4 Centralized Production of $\mathrm{H}_{2}$ via Electrolysis

A.5 Distributed Hydrogen Production and Dispensing Using Natural Gas

A.6 Distributed Hydrogen Production and Dispensing Using Electrolysis -

Detailed Results for Selected Regions.

A.7 Distributed Hydrogen Production and Dispensing Using Electrolysis Summary Results for Selected Regions.

B.1 SFA and DTI Estimates of the Cost of Distributed Hydrogen Production from Electrolysis

C.1 Key Assumptions in Regional $\mathrm{H}_{2}$ Model 1.0.

\section{FIGURES}

S-1 Final Delivered $\mathrm{H}_{2}$ Costs in GYOW by Region ......................................................... $\mathrm{x}$

S-2 Final Delivered $\mathrm{H}_{2}$ Cost in GYOW: U.S. Summary by Metropolitan versus Non-Metropolitan Areas

S-3 Sensitivity Run Assuming Continued Use of Natural Gas for Distributed

Production: Final Delivered $\mathrm{H}_{2}$ Costs in the United States

$\mathrm{xi}$

2.1 Total Demand of Three $\mathrm{H}_{2}$ Scenarios, 2015-2050 ………………………………....... 6

2.2 U.S. Census Divisions ......................................................................................... 


\section{FIGURES (CONT.)}

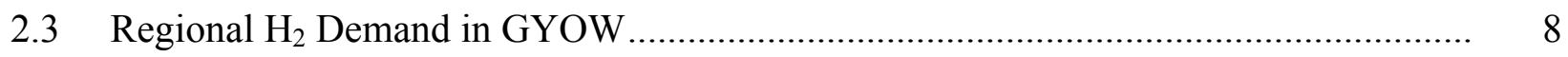

2.4 Non-Metropolitan Percentage of VMT and $\mathrm{H}_{2}$ Demand by Region ........................... 9

3.1 Regional Natural Gas Resource Characterization ............................................... 16

3.2 Regional Coal Resource Characterization ........................................................ 17

3.3 Regional Nuclear Resource Characterization ................................................. 17

3.4 Regional Renewables Resource Characterization ........................................... 18

3.5 Regional Biomass Resource Characterization .................................................... 18

3.6 Regional Wind Resource Characterization....................................................... 19

3.7 Regional Solar Resource Characterization ....................................................... 19

3.8 Resource Fuels Used to Produce $\mathrm{H}_{2}$ in GYOW: United States ................................ 25

3.9 Source of $\mathrm{H}_{2}$ in 2050 in GYOW Scenario by Region............................................ 27

4.1 Final Delivered $\mathrm{H}_{2}$ Cost in GYOW: U.S. Summary by $\mathrm{H}_{2}$

Production Technology ....................................................................................... 43

4.2 Final Delivered $\mathrm{H}_{2}$ Cost in GYOW: U.S. Summary by Metropolitan versus Non-Metropolitan Areas .................................................................................... 44

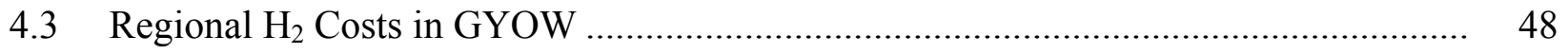




\section{ACKNOWLEDGMENTS}

The preparation of this report on regional $\mathrm{H}_{2}$ demand, production, and cost and the development of the Regional $\mathrm{H}_{2}$ Model 1.0 have been funded by the Office of Planning, Budget and Analysis of the Office of Energy Efficiency and Renewable Energy, U.S. Department of Energy. Philip Patterson has been the primary sponsor of this analytical effort, and we wish to thank him for his extensive support. We would also like to thank numerous reviewers of past versions of this draft, related papers, and presentations, particularly Steve Plotkin, Argonne National Laboratory. The authors are solely responsible for the report's contents. 


\section{SUMMARY}

This report presents an analysis of potential hydrogen $\left(\mathrm{H}_{2}\right)$ demand, production, and cost by region (i.e., U.S. Census Division) to $2050 .{ }^{1}$ The analysis was conducted to (1) address the Energy Information Administration's (EIA's) request for regional $\mathrm{H}_{2}$ cost estimates that will be input to its energy modeling system and (2) identify key regional issues associated with the use of $\mathrm{H}_{2}$ that need further study. Hydrogen costs may vary substantially by region. Many feedstocks may be used to produce $\mathrm{H}_{2}$, and the use of these feedstocks is likely to vary by region. For the same feedstock, regional variation exists in capital and energy costs. Furthermore, delivery costs are likely to vary by region: some regions are more rural than others, and so delivery costs will be higher. However, to date, efforts to comprehensively and consistently estimate future $\mathrm{H}_{2}$ costs have not yet assessed regional variation in these costs.

To develop the regional cost estimates and identify regional issues requiring further study, we developed a $\mathrm{H}_{2}$ demand scenario (called "Go Your Own Way" [GYOW]) that reflects fuel cell vehicle (FCV) market success to 2050 and allocated $\mathrm{H}_{2}$ demand by region and within regions by metropolitan versus non-metropolitan areas. Because we lacked regional resource supply curves to develop our $\mathrm{H}_{2}$ production estimates, we instead developed regional $\mathrm{H}_{2}$ production estimates by feedstock by (1) evaluating region-specific resource availability for centralized production of $\mathrm{H}_{2}$ and (2) estimating the amount of FCV travel in the nonmetropolitan areas of each region that might need to be served by distributed production of $\mathrm{H}_{2}$. Using a comprehensive $\mathrm{H}_{2}$ cost analysis developed by SFA Pacific, Inc., as a starting point, we then developed cost estimates for each $\mathrm{H}_{2}$ production and delivery method by region and over time (SFA Pacific, Inc. 2002). We assumed technological improvements over time to 2050 and regional variation in energy and capital costs. Although we estimate substantial reductions in $\mathrm{H}_{2}$ costs over time, our cost estimates are generally higher than the cost goals of the U.S. Department of Energy's (DOE's) hydrogen program.

The result of our analysis, in particular, demonstrates that there may be substantial variation in $\mathrm{H}_{2}$ costs between regions: as much as $\$ 2.04$ /gallon gasoline equivalent (GGE) by the time FCVs make up one-half of all light-vehicle sales in the GYOW scenario (2035-2040) and $\$ 1.85 /$ GGE by 2050 (excluding Alaska) (see Figure S-1 and Table 4.7). Given the assumptions we have made, our analysis also shows that there could be as much as a $\$ 4.82 /$ GGE difference in $\mathrm{H}_{2}$ cost between metropolitan and non-metropolitan areas by 2050 (national average). Our national average cost estimate by 2050 is $\$ 3.68 / \mathrm{GGE}$, but the average $\mathrm{H}_{2}$ cost in metropolitan areas in that year is $\$ 2.55 / \mathrm{GGE}$ and that in non-metropolitan areas is $\$ 7.37 / \mathrm{GGE}$ (see Figure S-2 and Table 4.9).

For these estimates, we assume that the use of natural gas to produce $\mathrm{H}_{2}$ is phased out. This phase-out reflects the desire of DOE's Office of Hydrogen, Fuel Cells and Infrastructure

\footnotetext{
1 We estimate cost, not price. Prices are market-driven and include taxes. Our costs are not market-driven and do not include taxes.
} 


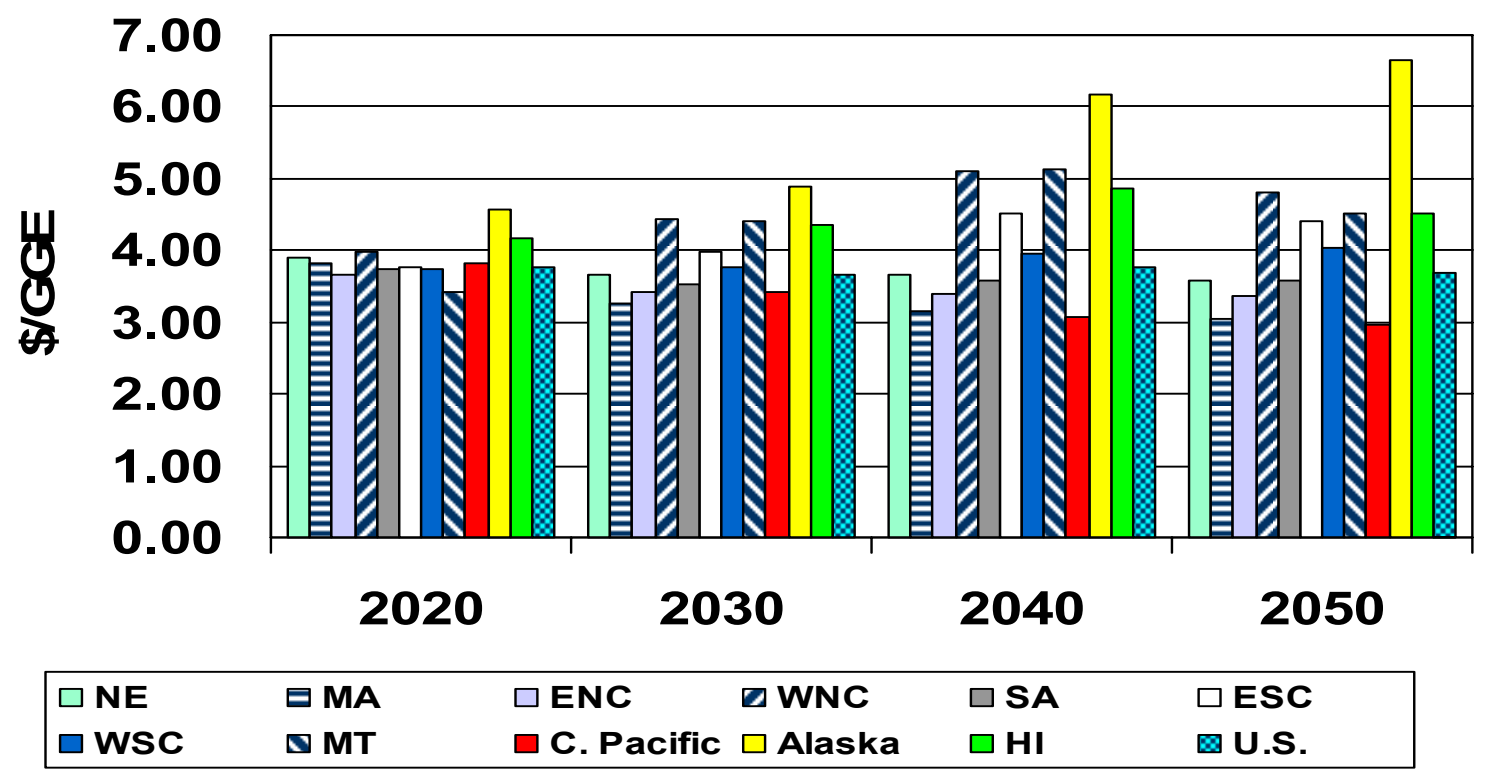

FIGURE S-1 Final Delivered $\mathrm{H}_{2}$ Costs in GYOW by Region

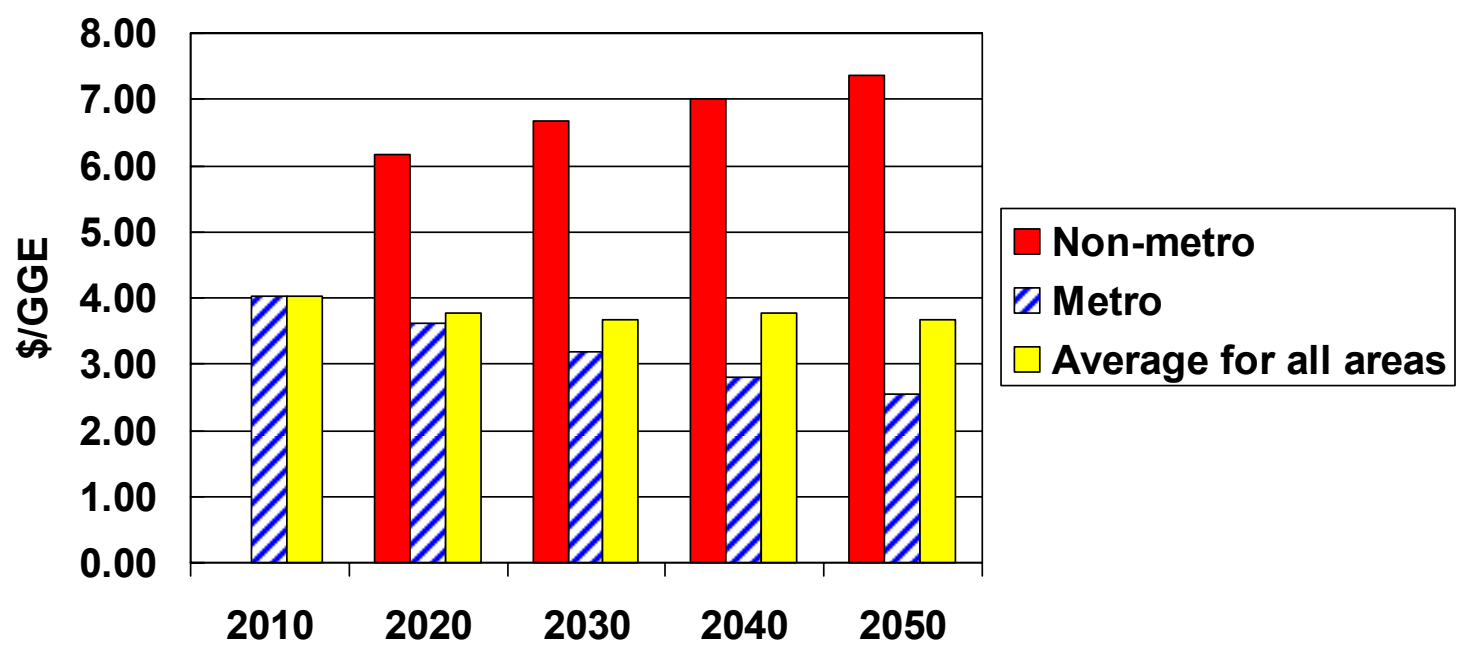

FIGURE S-2 Final Delivered $\mathrm{H}_{2}$ Cost in GYOW: U.S. Summary by Metropolitan versus Non-Metropolitan Areas

Technologies (OHFCIT) to eliminate reliance on natural gas for $\mathrm{H}_{2}$ production. We conducted a sensitivity run in which we allowed natural gas to continue to be used through 2050 for distributed production of $\mathrm{H}_{2}$ to see what effect changing that assumption had on costs. In effect, natural gas is used for $66 \%$ of all distributed production of $\mathrm{H}_{2}$ in this run. The national average cost is reduced to $\$ 3.10 / \mathrm{GGE}$, and the cost in non-metropolitan areas is reduced from $\$ 7.37 / \mathrm{GGE}$ to $\$ 4.90$, thereby reducing the difference between metropolitan and non-metropolitan areas to $\$ 2.35 /$ GGE (see Figure S-3 and Table 4.11). Although the cost difference is reduced, it is still substantial. Regional differences are similarly reduced, but they also remain substantial. 


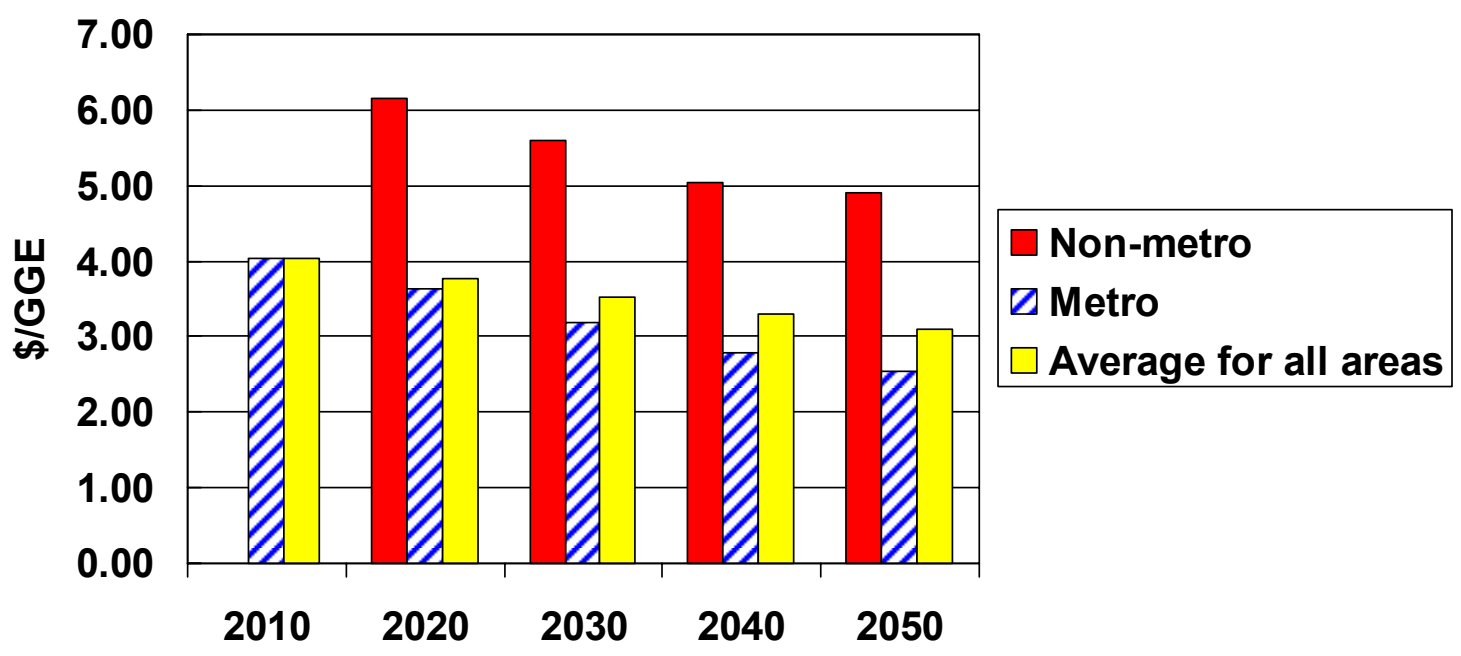

FIGURE S-3 Sensitivity Run Assuming Continued Use of Natural Gas for Distributed Production: Final Delivered $\mathrm{H}_{2}$ Costs in the United States

We also conducted a sensitivity run in which we cut in half our estimate of the cost of distributed production of $\mathrm{H}_{2}$ from electrolysis (our highest-cost production method). In this run, our national average cost estimate is reduced even further, to $\$ 2.89 / \mathrm{GGE}$, and the cost in nonmetropolitan areas is reduced to $\$ 4.01 /$ GGE. Thus, the difference between metropolitan and nonmetropolitan areas is reduced to $\$ 1.46 /$ GGE, but it remains substantial (see Table 4.11).

Given that these sensitivity runs demonstrate continued substantial differences between regions and between metropolitan and non-metropolitan areas, we believe that we have demonstrated the potential for significant differences in $\mathrm{H}_{2}$ cost between and within regions. We think the potential for these differences needs to be addressed in future $\mathrm{H}_{2}$ cost analyses.

Finally, there are many issues involved in adequately estimating what resources might be used to produce $\mathrm{H}_{2}$, how $\mathrm{H}_{2}$ demand will grow over time, and what $\mathrm{H}_{2}$ costs will be regionally and nationally. We have compiled a list of issues that reflects both issues that we faced and others that we believe need to be addressed to develop improved estimates of regional $\mathrm{H}_{2}$ demand, production, and cost. 


\section{HYDROGEN DEMAND, PRODUCTION, AND COST BY REGION TO 2050}

\section{INTRODUCTION}

A scenario of hydrogen $\left(\mathrm{H}_{2}\right)$ production and demand to 2050 by U.S. Census Division ("region" in this report) has been developed, and regional $\mathrm{H}_{2}$ costs per gallon gasoline equivalent (GGE) have been estimated for that scenario. Hydrogen cost estimates are essentially the costs to produce $\mathrm{H}_{2}$ and exclude taxes. We developed this scenario and generated cost estimates at the request of the U.S. Department of Energy (DOE), Office of Energy Efficiency and Renewable Energy, Office of Planning, Budget and Analysis. The purpose of developing this scenario and generating regional cost estimates was twofold:

1. To provide the Energy Information Administration (EIA) with $\mathrm{H}_{2}$ cost estimates that vary by region and over time. In the past, when EIA has modeled the use of $\mathrm{H}_{2}$ in fuel cell vehicles (FCVs) for its Annual Energy Outlook (AEO) projections, it has used a single $\mathrm{H}_{2}$ price across all U.S. Census Divisions and across time. EIA indicated that if $\mathrm{H}_{2}$ cost estimates could be developed that varied by region and over time, it would use them. The regional cost estimates developed in the analysis reported here were provided to EIA, which used them in development of the AEO 2005 (Maples 2004).

2. To identify key regional issues associated with the production and use of $\mathrm{H}_{2}$. Considerable analytical effort is under way to develop comprehensive and consistent estimates of the future costs of $\mathrm{H}_{2}$ and to evaluate alternative transitions to the use of FCVs (Mann 2004, Greene et al. 2004, and Woods 2005). Although at least two of these efforts will examine regional (as defined in this report) variations in $\mathrm{H}_{2}$ production, demand, and costs, to date they have not. The analysis reported here was conducted to help identify regional issues that need to be considered by these other analytical efforts.

In this report, we describe the assumptions we made in the development of the scenario and its $\mathrm{H}_{2}$ cost estimates. Most of the discussion focuses on how the production and cost estimates were derived for a given demand scenario (described in Section 2). We present the final production scenario and cost estimates. We also summarize key analytical issues that need to be addressed in developing such estimates.

We used an Excel spreadsheet model (the Regional $\mathrm{H}_{2}$ Model, version 1.0) to develop the final production scenario and cost estimates. Other $\mathrm{H}_{2}$ demand scenarios can be input to the model and alternative costs estimated. Where appropriate in the following sections, we indicate where other inputs (besides $\mathrm{H}_{2}$ demand) to the model can be varied. 


\section{HYDROGEN DEMAND SCENARIO}

\subsection{TOTAL DEMAND BY REGION}

Table 2.1 and Figure 2.1 present three scenarios of potential $\mathrm{H}_{2}$ demand from light-duty vehicles over time. One is the "EIA reference" case, which shows very little demand and is therefore uninteresting from the point of view of developing $\mathrm{H}_{2}$ cost estimates and fleshing out regional issues. Another scenario is called the "President's Hydrogen Fuel Initiative" in which nearly $100 \%$ of light vehicle stock in 2050 is estimated to be FCVs. A third is called the "Go Your Own Way" (GYOW) scenario, the name of which was developed in the joint DOE/Natural Resources Canada 2050 study (Patterson et al. 2003). In GYOW, FCV sales begin in 2015 and reach $50 \%$ of all light vehicle sales by 2035, when they plateau. (Some FCVs will be on the road by 2010 , but in limited niche markets.)

We have chosen to focus our analysis on the GYOW scenario because it is an optimistic, but intermediate, scenario of $\mathrm{H}_{2}$ demand. Using a stock model (VISION), we estimated that in that scenario, approximately $50 \%$ of all light vehicle stock will be FCVs by 2050 (Singh, Vyas, and Steiner 2003). The $\mathrm{H}_{2}$ demand of GYOW is substantial: nearly 6 quads (over 42 million metric tons or 45 billion GGE) by 2050 . We allocated this demand by state and region. Table 2.2 lists the states included in each region, and Figure 2.2 presents the regions. We split Alaska and Hawaii from the Pacific region totals and treated these non-contiguous states as separate regions.

Although the VISION model generates annual fuel use estimates, we only input its $\mathrm{H}_{2}$ demand estimates for the years 2010, 2020, 2030, 2040, and 2050 to the Regional $\mathrm{H}_{2} \mathrm{Model}_{\text {. }}$ (The year 2010 estimates are actually EIA's estimates.)

The regional allocation of $\mathrm{H}_{2}$ demand was made according to the year 2000 motor gasoline use; the regional shares were held constant over time (EIA 2000). In effect, we assumed that FCVs would penetrate the market at the same rate in the various U.S. regions over time (which we recognize is unlikely). Table 2.3 presents motor gasoline use in 2000 by U.S. region and $\mathrm{H}_{2}$ demand by 2050 in the GYOW scenario. Figure 2.3 presents regional $\mathrm{H}_{2}$ demand over time.

\subsection{WITHIN-REGION DEMAND}

We further allocated $\mathrm{H}_{2}$ demand within regions by metropolitan and non-metropolitan areas. We made this allocation because of our assumption that, in a scenario of significant FCV market penetration, FCVs will be used in the same manner as today's vehicles and thus will be used in both metropolitan and non-metropolitan areas. The cost of supplying $\mathrm{H}_{2}$ to metropolitan and non-metropolitan areas may vary considerably.

We used the metropolitan area designations provided by the U.S. Census, effective January 28, 2002 (U.S. Census Bureau 2002). The allocation of $\mathrm{H}_{2}$ demand within regions by 


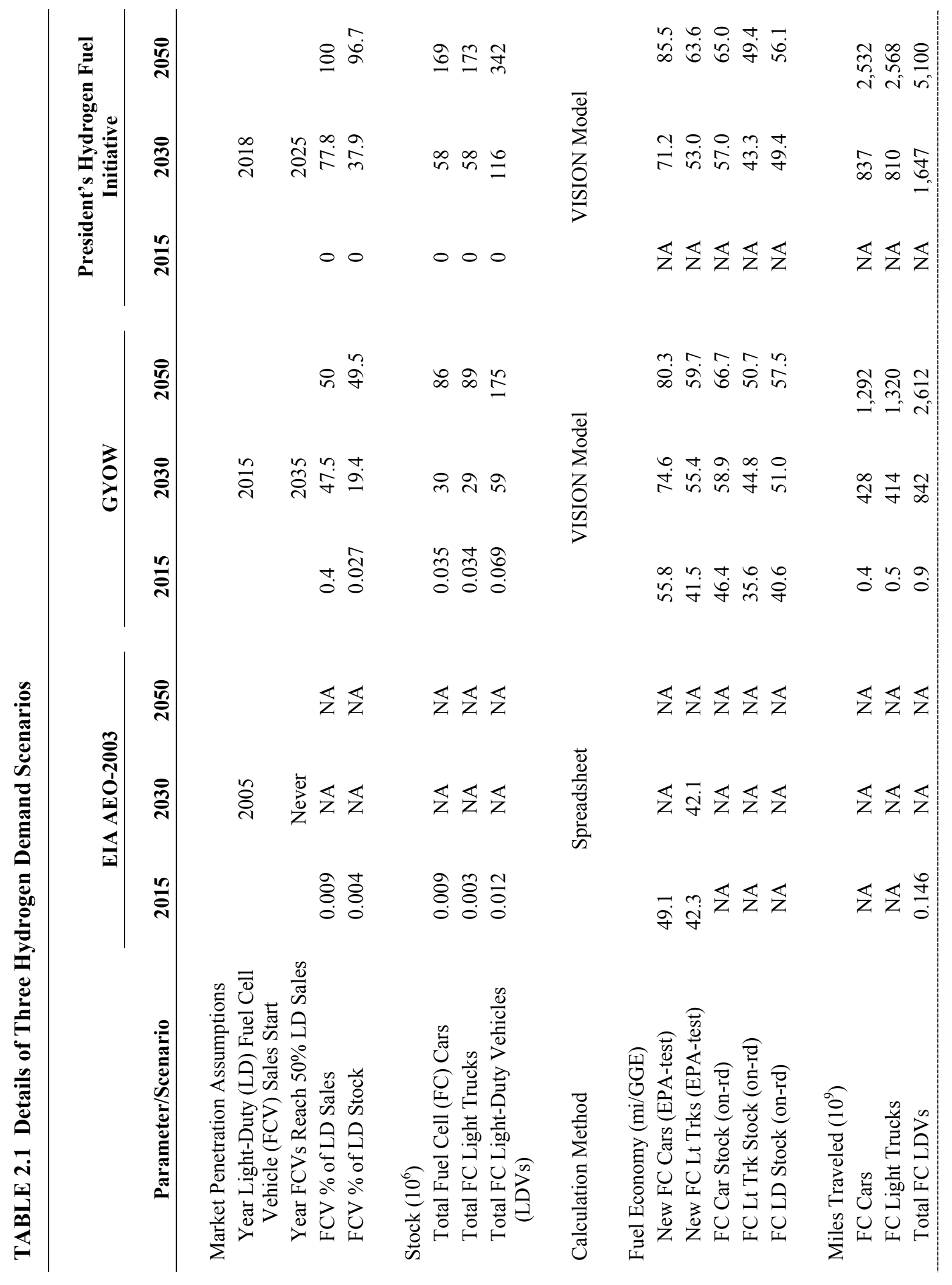




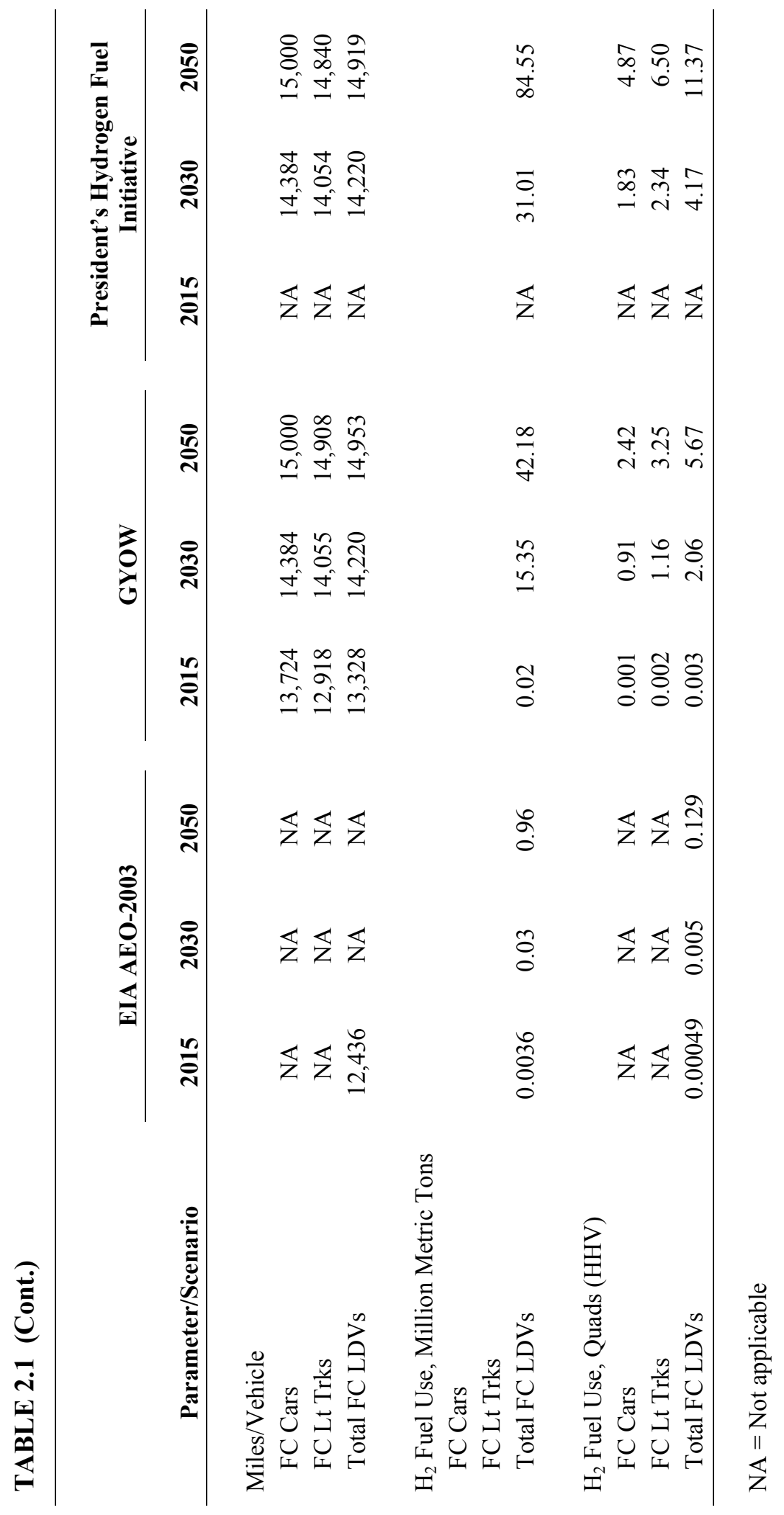




\section{Hydrogen Demand in Three Scenarios}

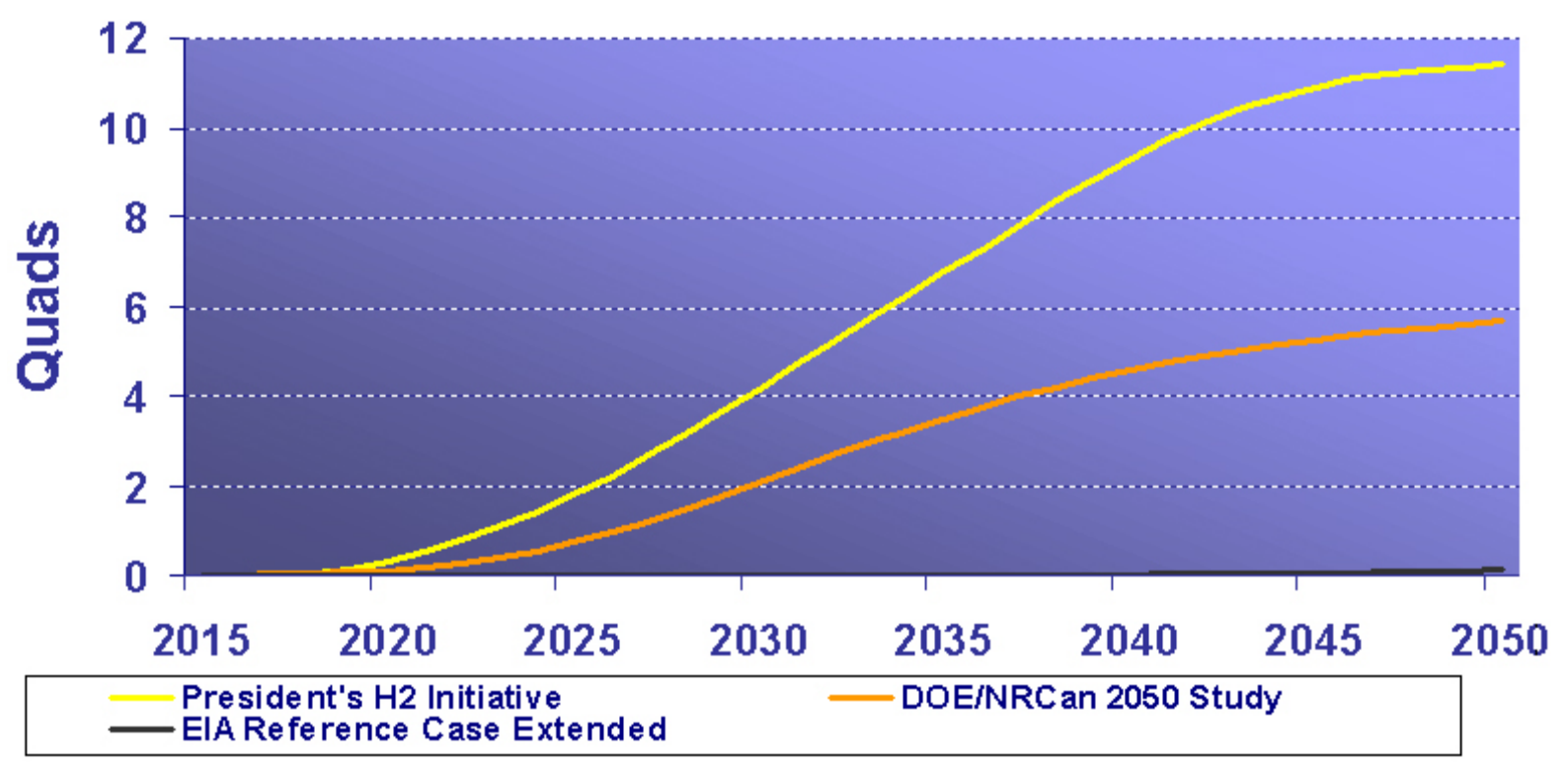

FIGURE 2.1 Total Demand of Three $\mathrm{H}_{2}$ Scenarios, 2015-2050

TABLE 2.2 Census Bureau Divisions

\begin{tabular}{|c|c|c|c|c|}
\hline Division 1 & Division 2 & Division 3 & Division 4 & Division 5 \\
\hline New England & Middle Atlantic & East North Central & West North Central & South Atlantic \\
\hline $\begin{array}{l}\text { Connecticut } \\
\text { Maine } \\
\text { Massachusetts } \\
\text { New Hampshire } \\
\text { Rhode Island } \\
\text { Vermont }\end{array}$ & $\begin{array}{l}\text { New Jersey } \\
\text { New York } \\
\text { Pennsylvania }\end{array}$ & $\begin{array}{l}\text { Illinois } \\
\text { Indiana } \\
\text { Michigan } \\
\text { Ohio } \\
\text { Wisconsin }\end{array}$ & $\begin{array}{l}\text { Iowa } \\
\text { Kansas } \\
\text { Minnesota } \\
\text { Missouri } \\
\text { Nebraska } \\
\text { North Dakota } \\
\text { South Dakota }\end{array}$ & $\begin{array}{l}\text { Delaware } \\
\text { District of Columbia } \\
\text { Florida } \\
\text { Georgia } \\
\text { Maryland } \\
\text { North Carolina } \\
\text { South Carolina } \\
\text { Virginia } \\
\text { West Virginia }\end{array}$ \\
\hline Division 6 & Division 7 & Division 8 & Division 9 & \\
\hline East South Central & West South Central & Mountain & Pacific & \\
\hline $\begin{array}{l}\text { Alabama } \\
\text { Kentucky } \\
\text { Mississippi } \\
\text { Tennessee }\end{array}$ & $\begin{array}{l}\text { Arkansas } \\
\text { Louisiana } \\
\text { Oklahoma } \\
\text { Texas }\end{array}$ & $\begin{array}{l}\text { Arizona } \\
\text { Colorado } \\
\text { Idaho } \\
\text { Montana } \\
\text { Nevada } \\
\text { New Mexico } \\
\text { Utah } \\
\text { Wyoming }\end{array}$ & $\begin{array}{l}\text { Alaska } \\
\text { California } \\
\text { Hawaii } \\
\text { Oregon } \\
\text { Washington }\end{array}$ & \\
\hline
\end{tabular}




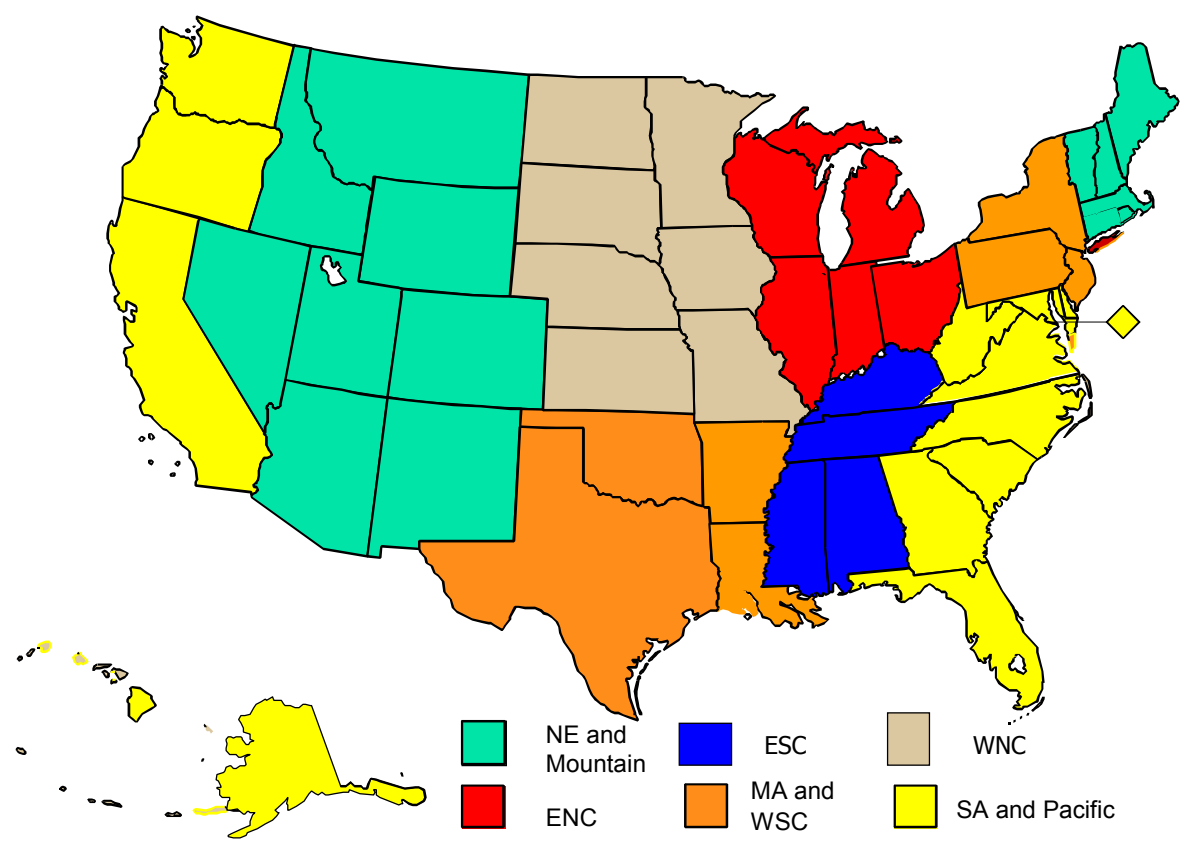

FIGURE 2.2 U.S. Census Divisions (NE = New England, ESC $=$ East South Central, WNC $=$ West North Central, ENC $=$ East North Central, MA $=$ Middle Atlantic, WSC $=$ West South Central, and SA $=$ South Atlantic)

TABLE 2.3 Total GYOW Demand and Production in 2050 by U.S. Region

\begin{tabular}{lcc}
\hline \multicolumn{1}{c}{ U.S. Census Divisions } & $\begin{array}{c}\text { Share of Total Gasoline } \\
\text { Use in 2000 }\end{array}$ & $\begin{array}{c}\mathbf{H}_{2} \text { Demand in } \\
\mathbf{2 0 5 0} \text { (Quads) }\end{array}$ \\
\hline New England & 0.048 & 0.275 \\
Middle Atlantic & 0.111 & 0.632 \\
East North Central & 0.159 & 0.899 \\
West North Central & 0.078 & 0.444 \\
South Atlantic & 0.199 & 1.126 \\
East South Central & 0.068 & 0.388 \\
West South Central & 0.123 & 0.695 \\
Mountain & 0.066 & 0.377 \\
Pacific (contiguous states only) & 0.143 & 0.809 \\
Alaska & 0.002 & 0.011 \\
Pacific & 0.003 & 0.017 \\
Total & 1.00 & 5.673 \\
\hline
\end{tabular}




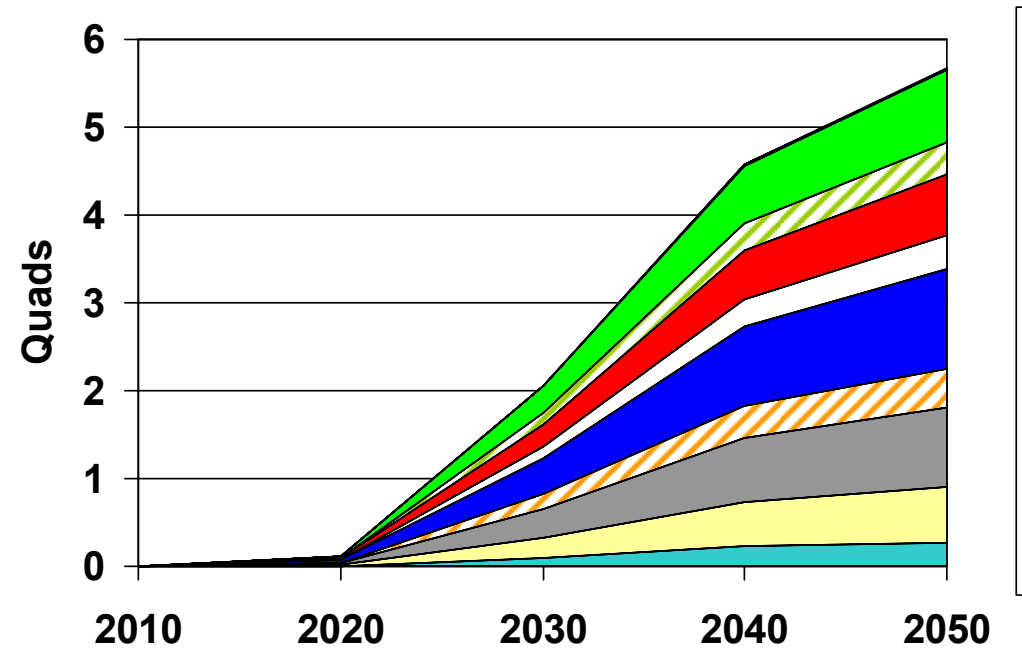

\begin{tabular}{|l|}
\hline$\square$ Hawaii \\
$\square$ Alaska \\
$\square$ Contiguous Pacific \\
$\square$ Mountain \\
$\square$ West South Central \\
$\square$ East South Central \\
$\square$ South Atlantic \\
$\square$ West North Central \\
$\square$ East North Central \\
$\square$ Middle Atlantic \\
$\square$ New England \\
\hline
\end{tabular}

Figure 2.3 Regional $\mathrm{H}_{2}$ Demand in GYOW

metropolitan and non-metropolitan areas was made on the basis of estimates of county-level light-vehicle vehicle miles traveled (VMT) provided by the U.S. Environmental Protection Agency (EPA) (EPA 2004). (In the New England states, in some instances, only part of a county is designated by the Census as metropolitan. For our purposes, a county that is "partly" metropolitan is considered entirely metropolitan.) Figure 2.4 illustrates the results of these assumptions. Of all light vehicle (LV) travel in the United States, 24\% is in non-metropolitan areas, and thus we assume that ultimately $24 \%$ of all $\mathrm{H}_{2}$ demand will be generated in nonmetropolitan areas. However, regional variation in that demand will be great, as illustrated in Figure 2.4.

Although we assume that ultimately $24 \%$ of all $\mathrm{H}_{2}$ demand will be generated in nonmetropolitan areas, we expect that there will be a gradual build-up to that share. Specifically, we assume that the only non-metropolitan travel by FCVs in 2020 will be along non-metropolitan interstates. Approximately 5\% of all LV travel is along such interstates. In 2030, we assume that approximately $14 \%$ of all FCV travel will be in non-metropolitan areas and by $2040,24 \%$ will be in non-metropolitan areas. Table 2.4 presents the final non-metropolitan $\mathrm{H}_{2}$ demand by year and region. 


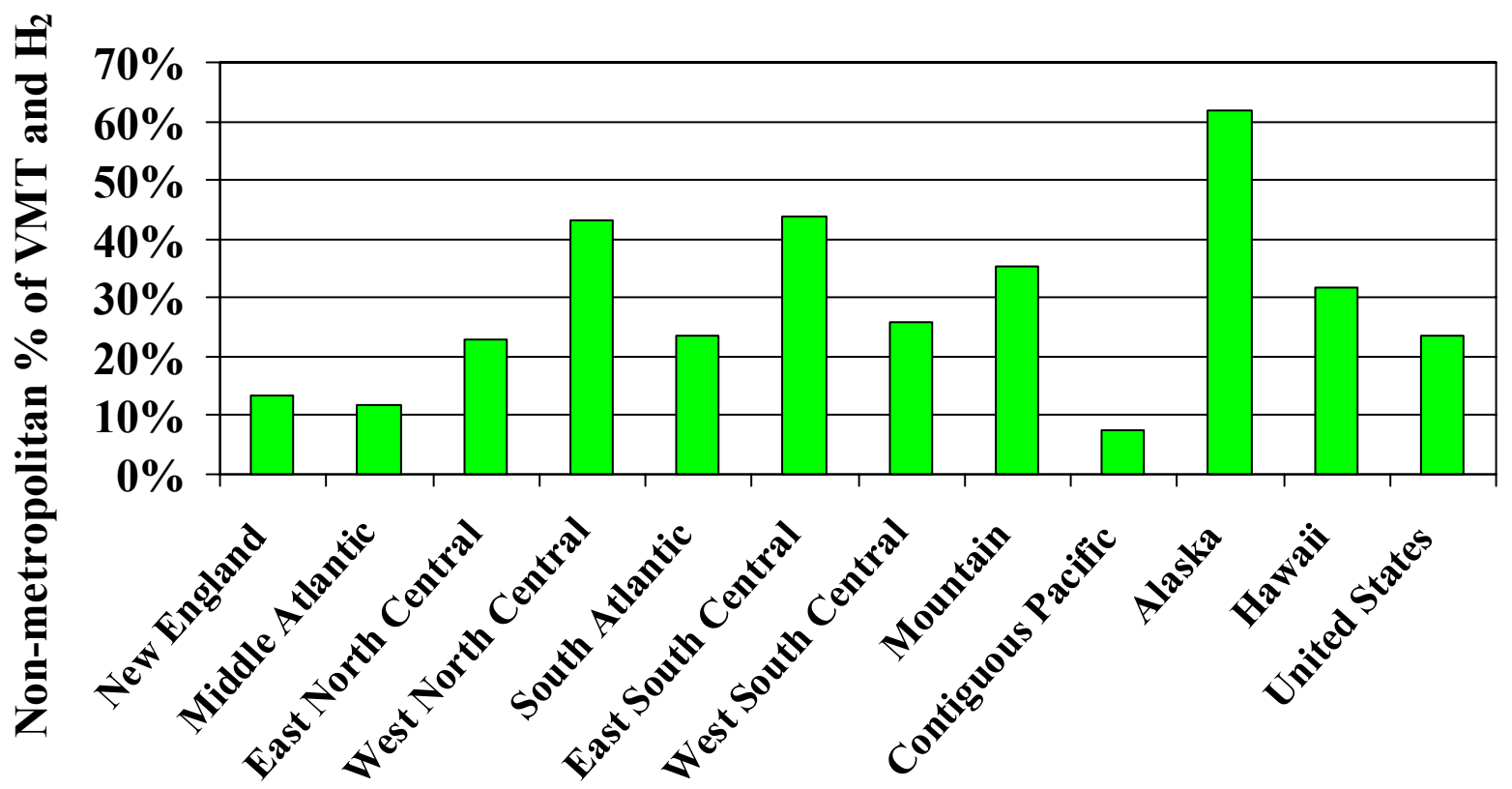

FIGURE 2.4 Non-Metropolitan Percentage of VMT and $\mathrm{H}_{2}$ Demand by Region

TABLE 2.4 Non-Metropolitan LV Travel and Assumed FCV Travel and Demand

\begin{tabular}{|c|c|c|c|c|c|}
\hline \multirow[b]{2}{*}{ Region } & \multirow{2}{*}{$\begin{array}{c}2002 \text { Share of } L V \\
\text { Travel on } \\
\text { Non-Metropolitan } \\
\text { Interstates (\%) } \\
\end{array}$} & \multirow{2}{*}{$\begin{array}{c}2002 \text { Share of } \mathrm{LV} \\
\text { Travel in } \\
\text { Non-Metropolitan } \\
\text { Areas (\%) }\end{array}$} & \multicolumn{3}{|c|}{$\begin{array}{l}\text { Assumed Share of FCV Travel and } \\
\text { Demand in Non-Metropolitan Areas }\end{array}$} \\
\hline & & & $\begin{array}{l}2020 \\
(\%)\end{array}$ & $\begin{array}{l}2030 \\
(\%)\end{array}$ & $\begin{array}{l}2040 \text { and } 2050 \\
(\%)\end{array}$ \\
\hline New England & 2.3 & 13.4 & 2.3 & 8.0 & 13.4 \\
\hline Middle Atlantic & 2.7 & 11.8 & 2.7 & 7.1 & 11.8 \\
\hline East North Central & 4.8 & 22.9 & 4.8 & 13.7 & 22.9 \\
\hline West North Central & 8.7 & 43.1 & 8.7 & 25.9 & 43.1 \\
\hline South Atlantic & 5.5 & 23.6 & 5.5 & 14.2 & 23.6 \\
\hline East South Central & 7.8 & 43.8 & 7.8 & 26.3 & 43.8 \\
\hline West South Central & 6.3 & 25.9 & 6.3 & 15.5 & 25.9 \\
\hline Mountain & 10.3 & 35.4 & 10.3 & 21.2 & 35.4 \\
\hline Contiguous Pacific & 2.0 & 7.5 & 2.0 & 4.5 & 7.5 \\
\hline Alaska & 18.2 & 61.7 & 18.2 & 37.0 & 61.7 \\
\hline Hawaii & 0.0 & 31.7 & 0.0 & 19.0 & 31.7 \\
\hline U.S. Total & 5.3 & 23.7 & 5.3 & 14.2 & 23.7 \\
\hline
\end{tabular}




\section{HYDROGEN PRODUCTION}

\subsection{OVERVIEW OF KEY ASSUMPTIONS USED IN ESTIMATING THE RESOURCES USED TO PRODUCE HYDROGEN}

Hydrogen can be produced from many resource fuels or feedstocks. Ideally, regional resource supply curves would be used to estimate which resources will be used to produce various volumes of $\mathrm{H}_{2}$ in the different regions. Given the lack of a comprehensive set of such curves at this time, we developed an alternative method of estimating the resources used in different regions to produce $\mathrm{H}_{2}$. Our method is based on a number of assumptions. We highlight the key assumptions below and discuss them in further detail in subsequent sections of this report. The key assumptions are:

1. Each region will produce sufficient $\mathrm{H}_{2}$ to meet the region's demand. We do not expect that to be the case ultimately, but we have chosen to make this assumption to simplify this initial analysis. We do think that, given all the potential sources of $\mathrm{H}_{2}$, a great deal of $\mathrm{H}_{2}$ may be produced from withinregion resources.

2. Relative resource availability in a region (i.e., the relative abundance of coal versus natural gas versus renewables, etc.) determines the likelihood of each resource being used to produce $\mathrm{H}_{2}$ in that region. Again, the main reason for taking this approach is that regional supply curves for all the resources of interest are not available.

3. Steam-reforming of natural gas and electrolysis (both centralized and distributed) will be the methods used to produce $\mathrm{H}_{2}$ initially when $\mathrm{H}_{2}$ demand is very low.

4. Both centralized and distributed production of $\mathrm{H}_{2}$ will be used throughout the time frame of this analysis.

5. Centralized production will provide the $\mathrm{H}_{2}$ used in metropolitan areas and some non-metropolitan areas, while distributed production $\left(\mathrm{H}_{2}\right.$ produced at service stations) will meet a large share of non-metropolitan area demand.

6. Use of natural gas to produce $\mathrm{H}_{2}$ will be phased out completely by 2050 .

In Sections 3.2-3.4, we discuss how we (1) characterized regional resource fuel availability, (2) estimated the share of $\mathrm{H}_{2}$ produced via distributed production, and (3) estimated what resources would be used to produce $\mathrm{H}_{2}$ (both distributed and central) over time. In Section 3.5, we present a final estimate of $\mathrm{H}_{2}$ production by resource fuel and centralized versus distributed production. 


\subsection{RESOURCES USED IN $\mathrm{H}_{2}$ PRODUCTION}

As stated above, we assume that steam-reforming of natural gas and electrolysis (both centralized and distributed) will be the methods used to produce $\mathrm{H}_{2}$ initially when $\mathrm{H}_{2}$ demand is very low. Over time, as $\mathrm{H}_{2}$ demand grows, $\mathrm{H}_{2}$ will be produced from divergent sources, particularly coal (with carbon sequestration); renewables; and thermochemical water splitting by using advanced, high-temperature nuclear power. Because resource availability varies across the country, different levels of each resource will be used across regions. (The levels of each resource will also be affected by the cost of producing the resource, but we do not account for that in this analysis.)

We used state-level resource information to rate the U.S. regions, as described below. We separate Alaska and Hawaii from the Pacific region, and so we actually characterize 11 regions.

1. For coal, EIA provides "estimated recoverable reserves" by state (EIA 2001). On the basis of these reserve amounts, we categorized the states into four groups: "a" (extensive reserves and therefore highly likely to use first and longest), "b" (moderate reserves and therefore likely to use if possible), "c" (limited reserves and therefore likely to look for other alternatives), and "d" (no reserves and therefore must look for other alternatives). Once each state was rated, the U.S. regions were characterized as "A," "B," "C," or "D" for coal based on the highest ranking achieved by any state within a region. The presumption underlying this characterization is that the coal resources of a state will not be limited to $\mathrm{H}_{2}$ production for that state alone, but it will be used for $\mathrm{H}_{2}$ production for closely associated states as well. The result of this characterization is that 5 of the 11 regions are ranked "A," 3 "B," 1 "C," and 2 " $\mathrm{D}$ " - not an unusual characterization, given that the United States is a coal-rich country.

2. For renewables, we characterized the biomass, wind, and solar resources of each state and region and then developed an overall renewables rating for each region. Oak Ridge National Laboratory (ORNL) has developed estimates of the cumulative volume of biomass that can be produced within each state at $\$ 50$ or less per dry ton (ORNL 2003). The National Renewable Energy Laboratory (NREL) has classified wind resource potential across the country. NREL's U.S. wind resource map was reviewed, and state-level resource potential estimates were developed (EERE 2003). Similarly, NREL has classified national solar resources. Maps of these resources were reviewed, and state-level resource potential estimates were developed (NREL 2003).

For each of these three resources, these state-level volumes and resource potential estimates were used to classify states as "a" (excellent resource), "b" (moderate) "c" (limited), or "d" (none or very little) in a manner very similar to that used for coal classification. Then, as with coal, the U.S. census regions were characterized as "A," "B," "C," or "D" for biomass, wind, and solar, on the basis of the highest ranking achieved by any state within a region. The 
presumption underlying this characterization is that the individual renewable resources of a state will not be limited to $\mathrm{H}_{2}$ production for that state alone, but it will be used for $\mathrm{H}_{2}$ production for closely associated states as well. The result of this characterization is that 5 of the 11 regions were ranked " $\mathrm{A}$ " for biomass, 5 for wind, and 4 for solar.

Once these estimates were made, each region was similarly categorized for renewables as a whole. Given that in the AEO 2003 EIA estimates a very small contribution by solar technology to electricity generation and end-use sector energy use relative to biomass and wind in 2025, we based the regional renewable classification on just the regional biomass and wind characterizations (EIA 2003a). The result of this characterization is that 7 of the 11 regions are ranked "A," 3 "B," and 1 "C" for renewable resources.

3. For $\mathbf{H}_{2}$ generation via thermochemical water splitting using advanced, high-temperature nuclear reactors, we assumed that these reactors will only be built in states with existing nuclear power plants. EIA data were used to develop a list of those states, and each state was classified as "yes" or "no" (EIA 2003b). We then used a weighted average to characterize a region's propensity to use nuclear power to generate $\mathrm{H}_{2}$. The weighted average accounted for each state's potential level of $\mathrm{H}_{2}$ demand (as estimated by its proportion of total LDV gasoline use in 2000) and whether the state was a "yes"(1) or "no"(0). The result of this characterization is that 8 of the 11 regions are ranked "Yes" and 3 "No."

4. For natural gas used in both centralized and distributed production, we used both state natural gas reserve estimates and the residential use of natural gas as indicators of a state's potential use of natural gas to produce $\mathrm{H}_{2}$ (EIA 2003a, EIA 2002). It is assumed that, for natural gas to be used extensively in a state to produce $\mathrm{H}_{2}$, an extensive natural gas distribution system will be required to deliver the natural gas to stations. It is also assumed that the relative level of natural gas for residential energy indicates the extent of the natural gas distribution system in a state. If a state does not have such an extensive system, it can overcome the current lack of local natural gas distribution only if it has extensive natural gas reserves.

Thus, states were classified into "a," "b," "c," or "d" categories similar to those used for coal and biomass, on the basis of EIA's estimates of natural gas reserves. States were also classified into those categories on the basis of EIA data showing the current share of residential energy use provided by natural gas. A state's ultimate rating is the highest of the two ratings (i.e., if is "a" for reserves, but "c" for residential energy use [e.g., Texas], the state received an "a" rating).

We then used a weighted average to characterize a region's propensity to use natural gas. The weighted average accounted for each state's potential level of 
$\mathrm{H}_{2}$ (as estimated by its proportion of total LDV gasoline use in 2000) and that state's natural gas ranking. The result of this characterization is that 2 of the 11 regions are ranked "A," 6 "B," 2 “C," and 1 "D."

5. For centralized electrolysis, we assumed that up to a maximum of $5 \%$ of today's regional electricity sales could be used to produce $\mathrm{H}_{2}$ throughout the time of the analysis (EIA 2003a). (The "electrolysis" referred to here makes use of electricity generated by existing power plants to produce $\mathrm{H}_{2}$. Production was assumed to typically occur during off-peak periods, when electricity prices are lowest.)

6. For distributed electrolysis, we assume that electricity is available everywhere. Table 3.1 presents the state and regional characterizations for natural gas, coal, renewables (and biomass, wind, and solar separately), and nuclear fuel. Figures 3.1-3.7 illustrate the regional characterization of the resource availability of these fuels. Table 3.2 presents our assumption of the maximum volume of $\mathrm{H}_{2}$ that can be generated via centralized electrolysis, presuming the use of lowest-cost electricity.

\subsection{SHARE OF $\mathrm{H}_{2}$ GENERATED BY DISTRIBUTED PRODUCTION BY RESOURCE FUEL}

We begin our estimation of the resource fuels used to produce $\mathrm{H}_{2}$ by estimating the amount of $\mathrm{H}_{2}$ that will be produced at service stations. Essentially, we assume that distributed production will be the only $\mathrm{H}_{2}$ production method possible for some of the more rural areas (i.e., non-metropolitan areas) of the United States. Thus, we first estimated how much distributed production would be required in these areas and assumed that centralized production (from a variety of resource fuels) would provide the remaining $\mathrm{H}_{2}$ in the rest of the country.

As indicated in Section 2, we assume that FCVs will eventually be used throughout the United States to meet the same travel demands as are met by existing vehicles. We also assume that, initially, FCV travel in non-metropolitan areas will only be along interstates. We assume that in 2020 , all that travel $(5.3 \%$ on average per Table 2.4 , with regional variation) will be fueled by $\mathrm{H}_{2}$ produced at stations. Table 2.4 also presents an estimate of the amount of nonmetropolitan travel by FCVs in 2030, 2040, and 2050 (14.2\%, 23.7\%, and 23.7\%, respectively). We expect that a large proportion of that travel will have to be fueled by $\mathrm{H}_{2}$ produced at service stations. What that proportion might be is debatable: we assume $75 \%$ in each of those years. Table 3.3 presents the results of these assumptions: the share of all $\mathrm{H}_{2}$ production that is distributed production by region by year.

We only assumed that two resource fuels would be used for distributed production of $\mathrm{H}_{2}$ : natural gas and electricity. Natural gas is generally much less expensive to use than electricity, 
TABLE 3.1 Regional $\mathrm{H}_{2}$ Resource Fuel Characterizations

\begin{tabular}{|c|c|c|c|c|c|c|c|}
\hline & $\begin{array}{c}\text { Natural Gas } \\
\text { Characterization }\end{array}$ & $\begin{array}{c}\text { Coal } \\
\text { Resources }\end{array}$ & $\begin{array}{c}\text { Renewables } \\
\text { Characterization }\end{array}$ & Biomass & Wind & Solar & $\begin{array}{c}\text { Nuclear } \\
\text { Characterization }\end{array}$ \\
\hline NEW ENGLAND & $\mathbf{C}$ & D & B & $\mathbf{C}$ & $\mathbf{A}$ & D & Yes \\
\hline Connecticut & $\mathrm{c}$ & $\mathrm{d}$ & & $\mathrm{d}$ & $\mathrm{c}$ & $\mathrm{d}$ & Yes \\
\hline Maine & $\mathrm{d}$ & d & & $\mathrm{c}$ & $\mathrm{b}$ & d & No \\
\hline Massachusetts & $\mathrm{b}$ & $d$ & & $\mathrm{c}$ & $\mathrm{b}$ & $\mathrm{d}$ & Yes \\
\hline New Hampshire & $\mathrm{d}$ & $\mathrm{d}$ & & $\mathrm{c}$ & $\mathrm{b}$ & $\mathrm{d}$ & Yes \\
\hline Rhode Island & $\mathrm{b}$ & $\mathrm{d}$ & & $\mathrm{d}$ & $\mathrm{c}$ & $\mathrm{d}$ & No \\
\hline Vermont & $\mathrm{d}$ & $\mathrm{d}$ & & $\mathrm{c}$ & $\mathrm{a}$ & $\mathrm{d}$ & Yes \\
\hline MIDDLE ATLANTIC & B & $\mathbf{A}$ & B & B & B & D & Yes \\
\hline New Jersey & $\mathrm{a}$ & $\mathrm{d}$ & & d & $\mathrm{c}$ & $\mathrm{d}$ & Yes \\
\hline New York & $\mathrm{b}$ & $\mathrm{d}$ & & $\mathrm{b}$ & $\mathrm{b}$ & $\mathrm{d}$ & Yes \\
\hline Pennsylvania & $\mathrm{b}$ & $\mathrm{a}$ & & $\mathrm{b}$ & $\mathrm{b}$ & $\mathrm{d}$ & Yes \\
\hline EAST NORTH CENTRAL & $\mathbf{A}$ & $\mathbf{A}$ & $\mathbf{A}$ & $\mathbf{A}$ & B & D & Yes \\
\hline Illinois & $\mathrm{a}$ & $\mathrm{a}$ & & $\mathrm{a}$ & $\mathrm{c}$ & $\mathrm{d}$ & Yes \\
\hline Indiana & $\mathrm{b}$ & $\mathrm{b}$ & & $\mathrm{a}$ & $\mathrm{c}$ & $\mathrm{d}$ & No \\
\hline Michigan & $\mathrm{a}$ & $\mathrm{c}$ & & $\mathrm{b}$ & $\mathrm{b}$ & $\mathrm{d}$ & Yes \\
\hline Ohio & $\mathrm{a}$ & $\mathrm{a}$ & & $\mathrm{a}$ & $\mathrm{c}$ & $\mathrm{d}$ & Yes \\
\hline Wisconsin & $\mathrm{b}$ & $\mathrm{d}$ & & $\mathrm{b}$ & $\mathrm{c}$ & $\mathrm{d}$ & Yes \\
\hline WEST NORTH CENTRAL & B & B & $\mathbf{A}$ & $\mathbf{A}$ & $\mathbf{A}$ & B & Yes \\
\hline Iowa & $\mathrm{b}$ & $\mathrm{b}$ & & $\mathrm{a}$ & $\mathrm{a}$ & c & Yes \\
\hline Kansas & $\mathrm{b}$ & $\mathrm{c}$ & & $\mathrm{a}$ & a & $\mathrm{b}$ & Yes \\
\hline Minnesota & $\mathrm{b}$ & $\mathrm{d}$ & & $\mathrm{a}$ & a & $\mathrm{d}$ & Yes \\
\hline Missouri & $\mathrm{b}$ & $\mathrm{b}$ & & $\mathrm{a}$ & $\mathrm{c}$ & $\mathrm{c}$ & Yes \\
\hline Nebraska & $\mathrm{b}$ & $\mathrm{d}$ & & $\mathrm{a}$ & $\mathrm{a}$ & $\mathrm{b}$ & Yes \\
\hline North Dakota & $\mathrm{c}$ & $\mathrm{b}$ & & a & a & $\mathrm{c}$ & No \\
\hline South Dakota & $\mathrm{c}$ & $\mathrm{c}$ & & $\mathrm{a}$ & $\mathrm{a}$ & $\mathrm{c}$ & No \\
\hline SOUTH ATLANTIC & C & $\mathbf{A}$ & $\mathbf{A}$ & $\mathbf{A}$ & B & C & Yes \\
\hline Delaware & $\mathrm{c}$ & $\mathrm{d}$ & & $\mathrm{d}$ & $\mathrm{d}$ & $\mathrm{d}$ & No \\
\hline $\mathrm{DC}$ & $\mathrm{a}$ & d & & $\mathrm{d}$ & d & d & No \\
\hline Florida & $\mathrm{c}$ & $\mathrm{d}$ & & $\mathrm{b}$ & $\mathrm{d}$ & $\mathrm{c}$ & Yes \\
\hline Georgia & $\mathrm{c}$ & $\mathrm{c}$ & & $\mathrm{a}$ & $\mathrm{d}$ & $\mathrm{c}$ & Yes \\
\hline Maryland & $\mathrm{c}$ & $\mathrm{c}$ & & $\mathrm{c}$ & $\mathrm{c}$ & $\mathrm{d}$ & Yes \\
\hline North Carolina & $\mathrm{d}$ & $\mathrm{c}$ & & $\mathrm{b}$ & $\mathrm{c}$ & $\mathrm{c}$ & Yes \\
\hline South Carolina & d & $\mathrm{d}$ & & $\mathrm{b}$ & $\mathrm{d}$ & $\mathrm{c}$ & Yes \\
\hline Virginia & $\mathrm{b}$ & $\mathrm{b}$ & & $\mathrm{b}$ & $\mathrm{c}$ & $\mathrm{d}$ & Yes \\
\hline West Virginia & $\mathrm{b}$ & $\mathrm{a}$ & & $\mathrm{c}$ & $\mathrm{b}$ & $\mathrm{d}$ & No \\
\hline EAST SOUTH CENTRAL & B & $\mathbf{A}$ & B & $\mathbf{A}$ & $\mathbf{C}$ & C & Yes \\
\hline Alabama & $\mathrm{b}$ & $\mathrm{b}$ & & $\mathrm{a}$ & $\mathrm{d}$ & $\mathrm{c}$ & Yes \\
\hline Kentucky & $\mathrm{b}$ & $\mathrm{a}$ & & $\mathrm{b}$ & $\mathrm{d}$ & $\mathrm{d}$ & No \\
\hline Mississippi & $\mathrm{c}$ & $\mathrm{c}$ & & $\mathrm{a}$ & $\mathrm{d}$ & $\mathrm{c}$ & Yes \\
\hline Tennessee & $\mathrm{c}$ & $\mathrm{c}$ & & $\mathrm{a}$ & $\mathrm{c}$ & $\mathrm{c}$ & Yes \\
\hline WEST SOUTH CENTRAL & $\mathbf{A}$ & B & $\mathbf{A}$ & $\mathbf{A}$ & $\mathbf{A}$ & $\mathbf{A}$ & Yes \\
\hline Arkansas & $\mathrm{b}$ & $\mathrm{c}$ & & $\mathrm{b}$ & $\mathrm{c}$ & $\mathrm{c}$ & Yes \\
\hline Louisiana & $\mathrm{b}$ & $\mathrm{c}$ & & $\mathrm{b}$ & $\mathrm{d}$ & $\mathrm{c}$ & Yes \\
\hline Oklahoma & $\mathrm{a}$ & $\mathrm{c}$ & & $\mathrm{b}$ & $\mathrm{a}$ & $\mathrm{b}$ & No \\
\hline Texas & $\mathrm{a}$ & $\mathrm{b}$ & & $\mathrm{a}$ & $\mathrm{b}$ & $\mathrm{a}$ & Yes \\
\hline MOUNTAIN & B & $\mathbf{A}$ & $\mathbf{A}$ & B & $\mathbf{A}$ & $\mathbf{A}$ & No \\
\hline Arizona & d & $\mathrm{c}$ & & $\mathrm{c}$ & $\mathrm{d}$ & $\mathrm{a}$ & Yes \\
\hline Colorado & $\mathrm{a}$ & $\mathrm{b}$ & & $\mathrm{c}$ & $\mathrm{a}$ & $\mathrm{a}$ & No \\
\hline Idaho & $\mathrm{c}$ & $\mathrm{c}$ & & $\mathrm{b}$ & a & $\mathrm{b}$ & No \\
\hline Montana & $\mathrm{b}$ & $\mathrm{a}$ & & $\mathrm{c}$ & $\mathrm{a}$ & $\mathrm{c}$ & No \\
\hline Nevada & $\mathrm{c}$ & $\mathrm{d}$ & & $\mathrm{d}$ & $\mathrm{b}$ & $\mathrm{a}$ & No \\
\hline New Mexico & $\mathrm{a}$ & $\mathrm{b}$ & & $\mathrm{c}$ & $\mathrm{b}$ & $\mathrm{a}$ & No \\
\hline Utah & $\mathrm{a}$ & $\mathrm{b}$ & & $\mathrm{d}$ & $\mathrm{b}$ & $\mathrm{a}$ & No \\
\hline Wyoming & $\mathrm{a}$ & $\mathrm{a}$ & & $\mathrm{c}$ & $\mathrm{a}$ & $\mathrm{b}$ & No \\
\hline
\end{tabular}


TABLE 3.1 (Cont.)

\begin{tabular}{|c|c|c|c|c|c|c|c|}
\hline & $\begin{array}{c}\text { Natural Gas } \\
\text { Characterization } \\
\end{array}$ & $\begin{array}{c}\text { Coal } \\
\text { Resources } \\
\end{array}$ & $\begin{array}{c}\text { Renewables } \\
\text { Characterization }\end{array}$ & Biomass & Wind & Solar & $\begin{array}{c}\text { Nuclear } \\
\text { Characterization }\end{array}$ \\
\hline CONTIGUOUS PACIFIC & B & $\mathbf{C}$ & $\mathbf{A}$ & B & $\mathbf{A}$ & $\mathbf{A}$ & Yes \\
\hline California & $\mathrm{b}$ & $\mathrm{d}$ & & $\mathrm{b}$ & $\mathrm{a}$ & $\mathrm{a}$ & Yes \\
\hline Oregon & $\mathrm{c}$ & c & & $\mathrm{b}$ & a & $\mathrm{b}$ & No \\
\hline Washington & $\mathrm{c}$ & $\mathrm{c}$ & & $\mathrm{b}$ & $\mathrm{a}$ & c & Yes \\
\hline ALASKA & B & B & C & D & B & D & No \\
\hline Alaska & $\mathrm{b}$ & $\mathrm{b}$ & & d & $\mathrm{b}$ & d & No \\
\hline HAWAII & D & D & $\mathbf{A}$ & B & $\mathbf{A}$ & $\mathbf{A}$ & No \\
\hline Hawaii & d & d & & $\mathrm{b}$ & a & a & No \\
\hline
\end{tabular}

A = High resource availability for coal and renewables. For natural gas, natural gas consumption is substantial and thus presumably so is distribution system; $\mathrm{B}=$ Region can use these resources for a long time, although they must look to others as well; $\mathrm{C}=$ Region is likely to look for other alternatives; $\mathrm{D}=$ Low resource availability for coal and renewables. For natural gas, natural gas consumption is insignificant and thus presumably so is distribution system.

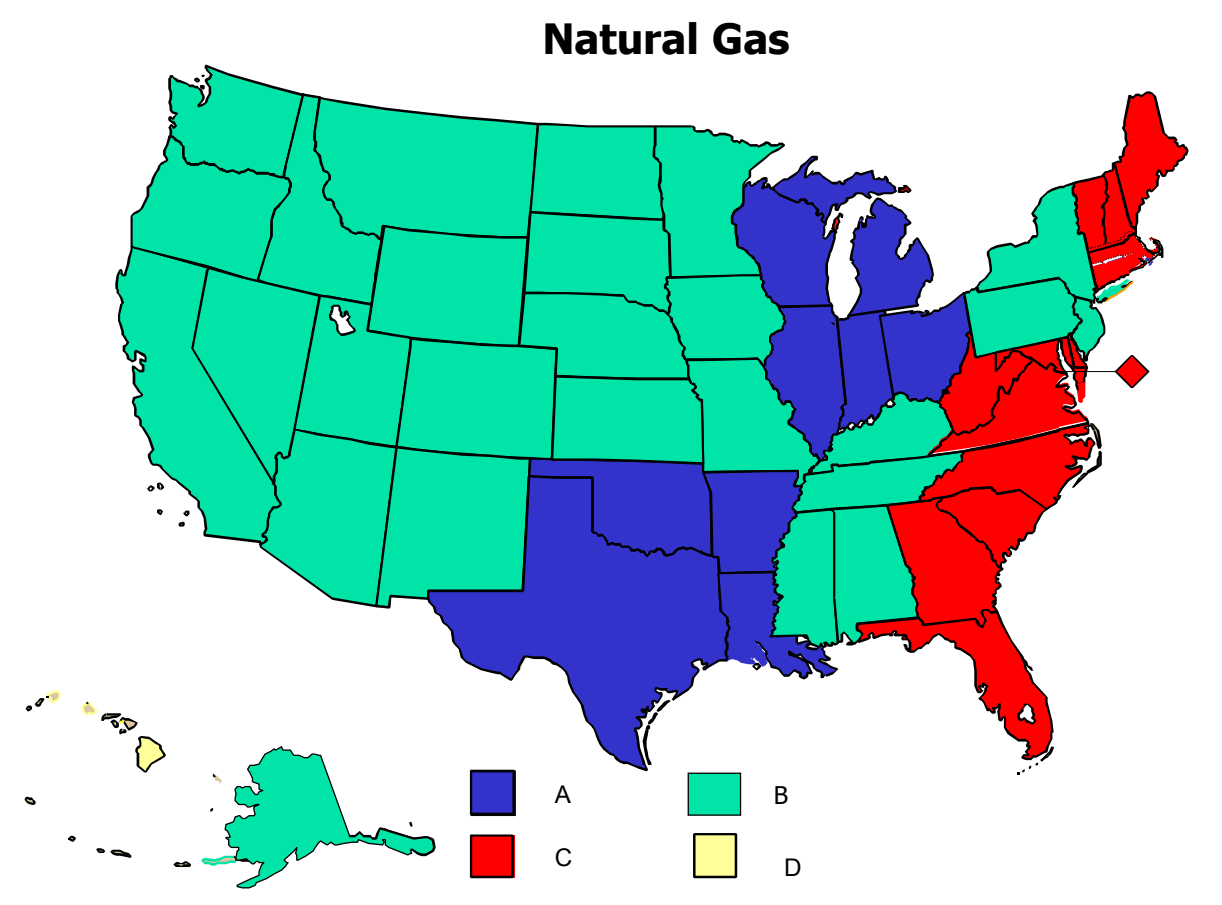

FIGURE 3.1 Regional Natural Gas Resource Characterization 


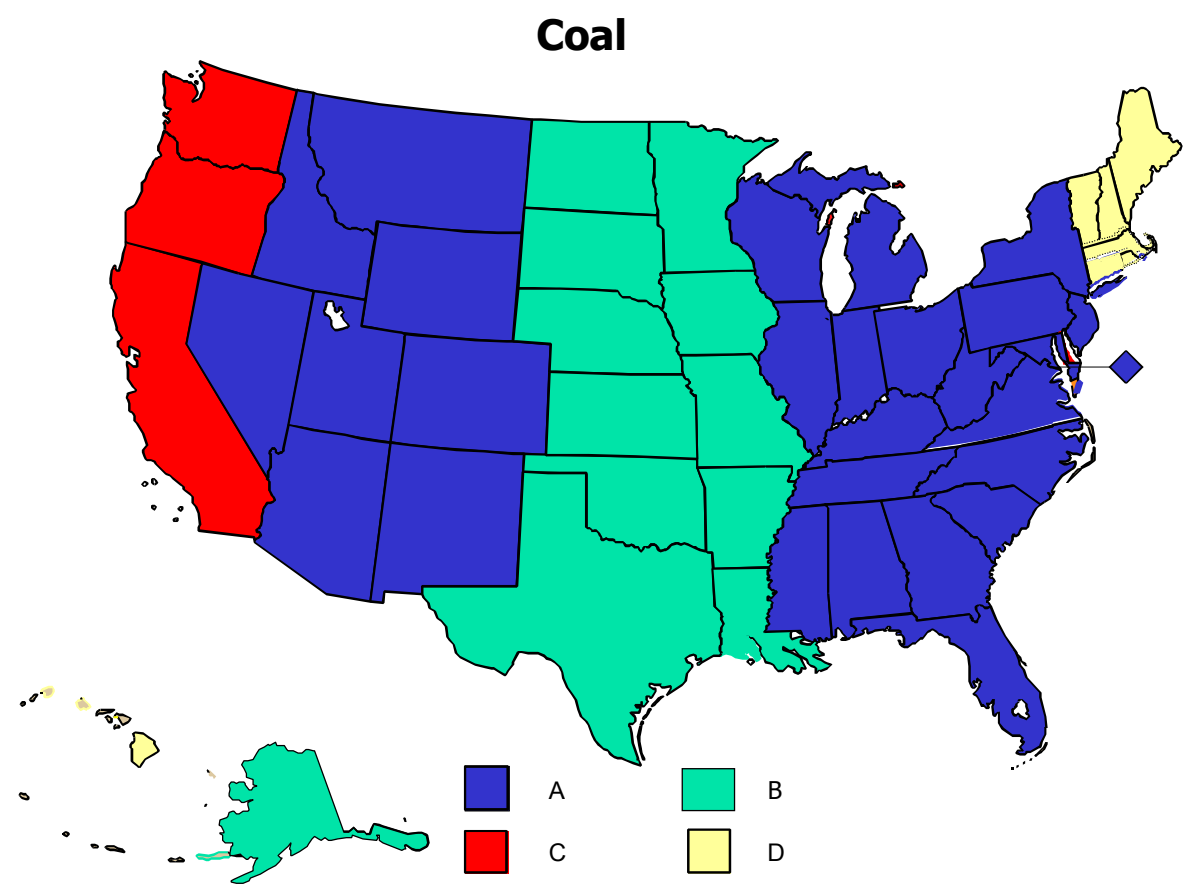

FIGURE 3.2 Regional Coal Resource Characterization

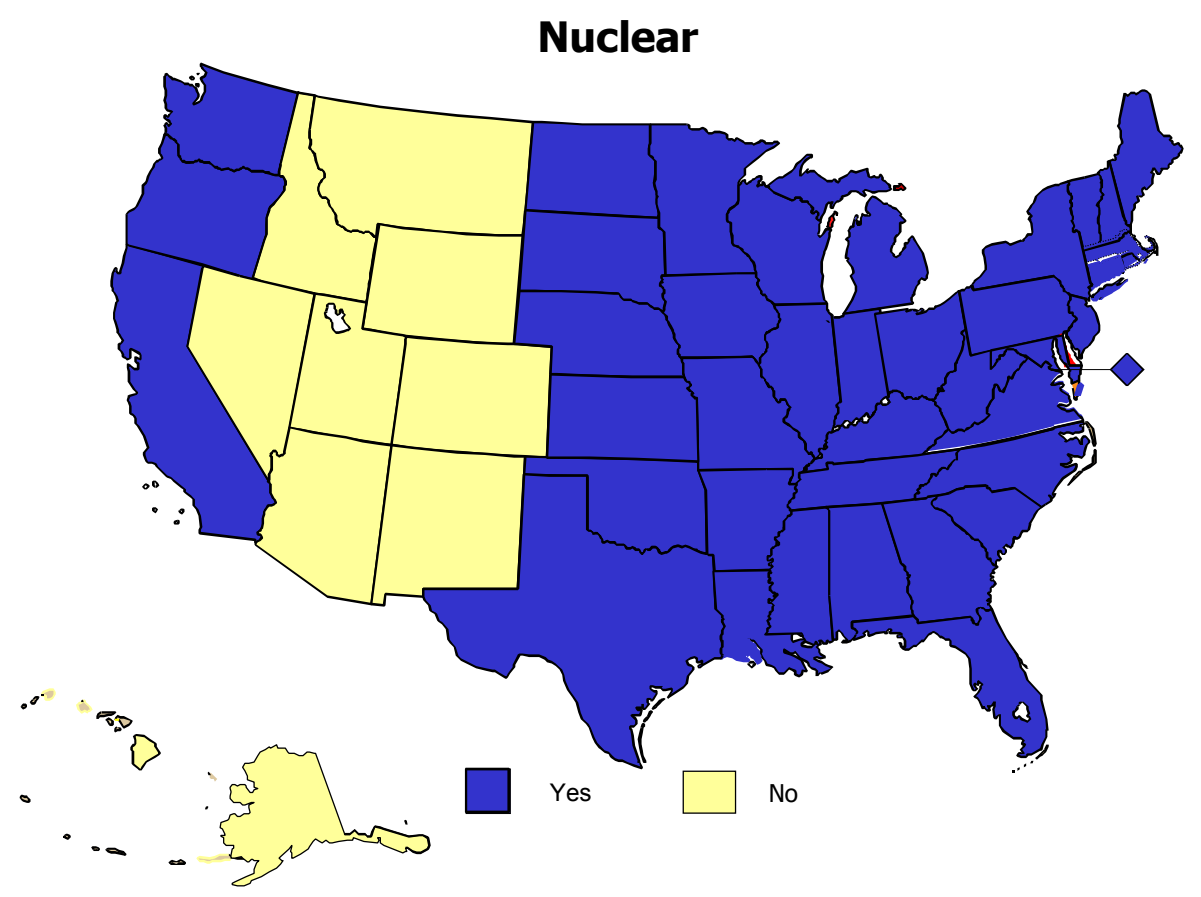

FIGURE 3.3 Regional Nuclear Resource Characterization 


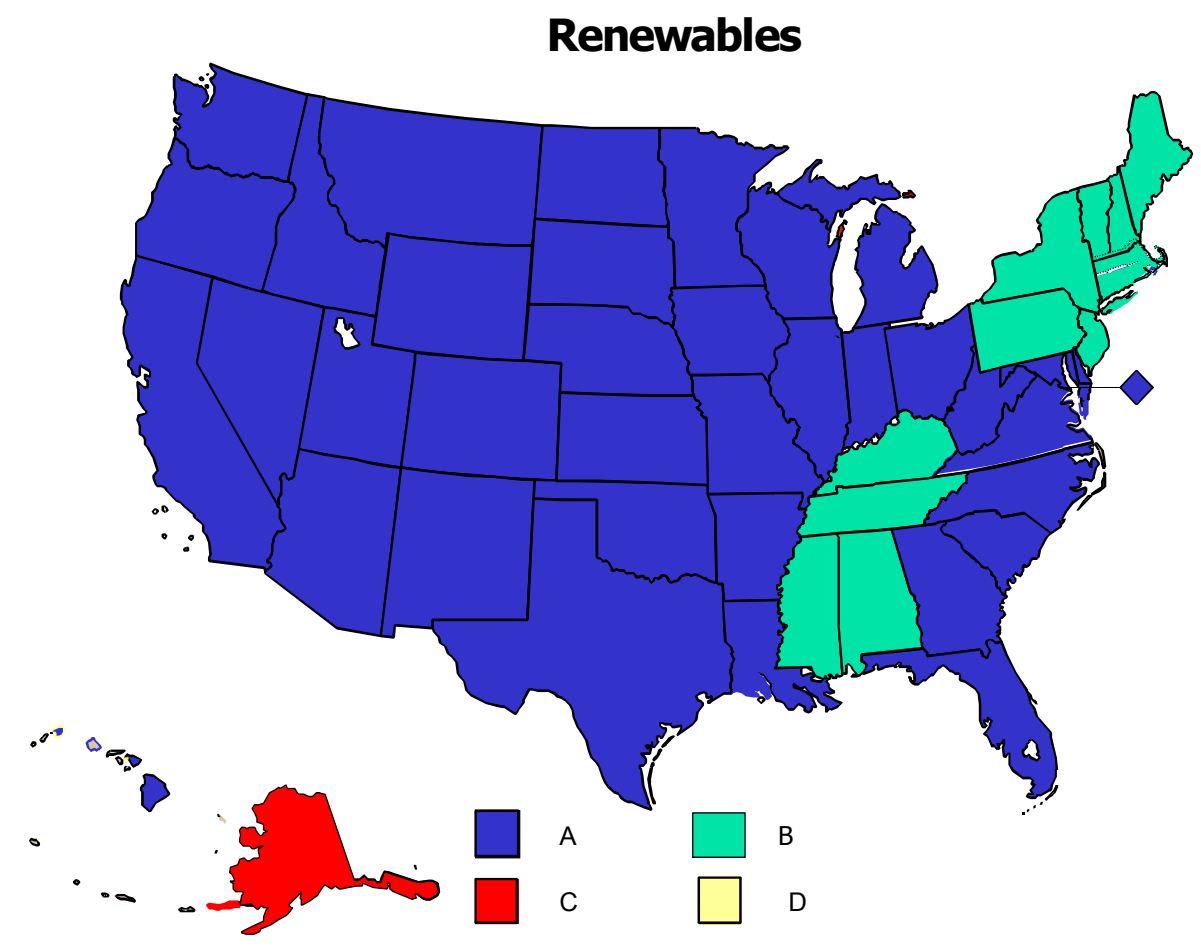

FIGURE 3.4 Regional Renewables Resource Characterization

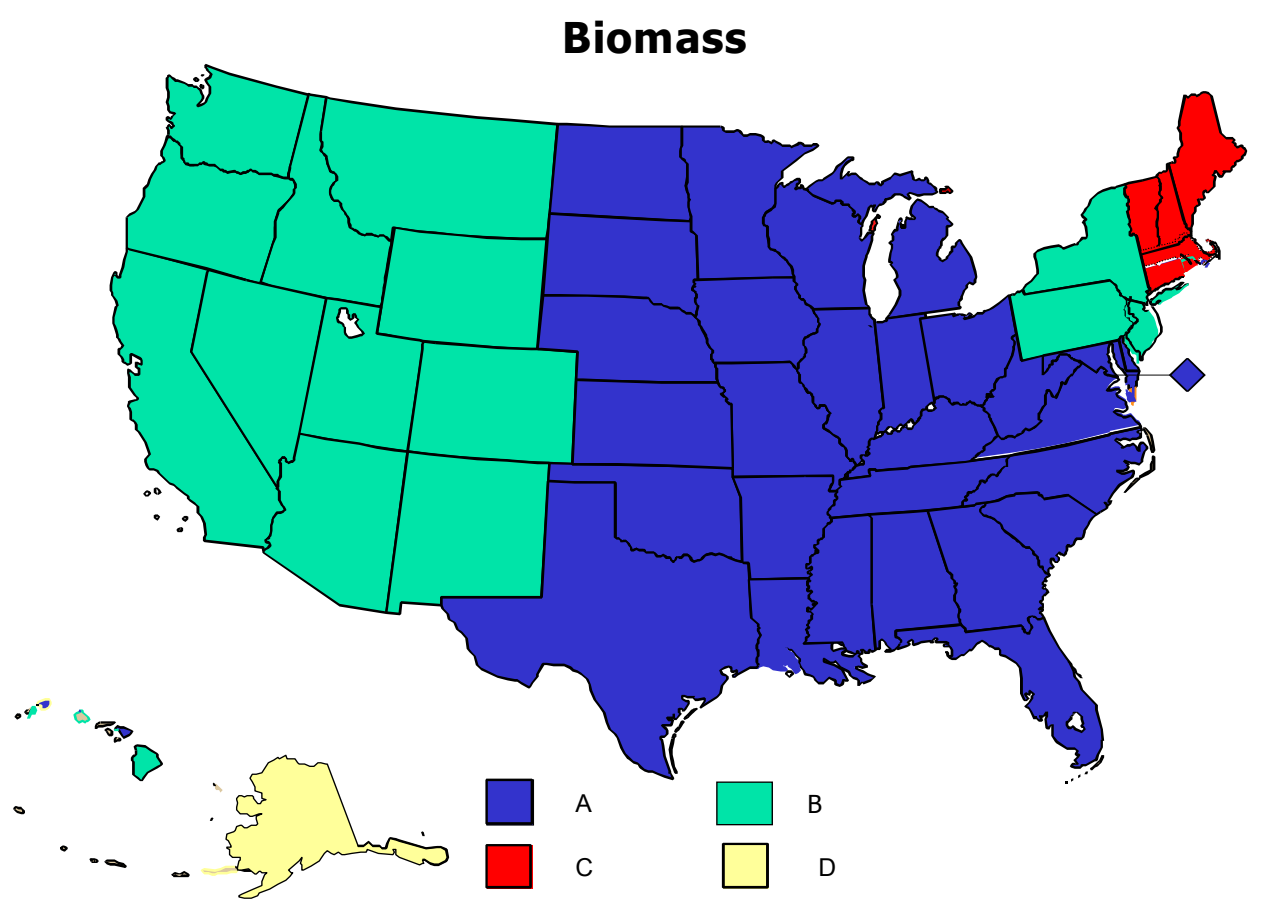

FIGURE 3.5 Regional Biomass Resource Characterization 


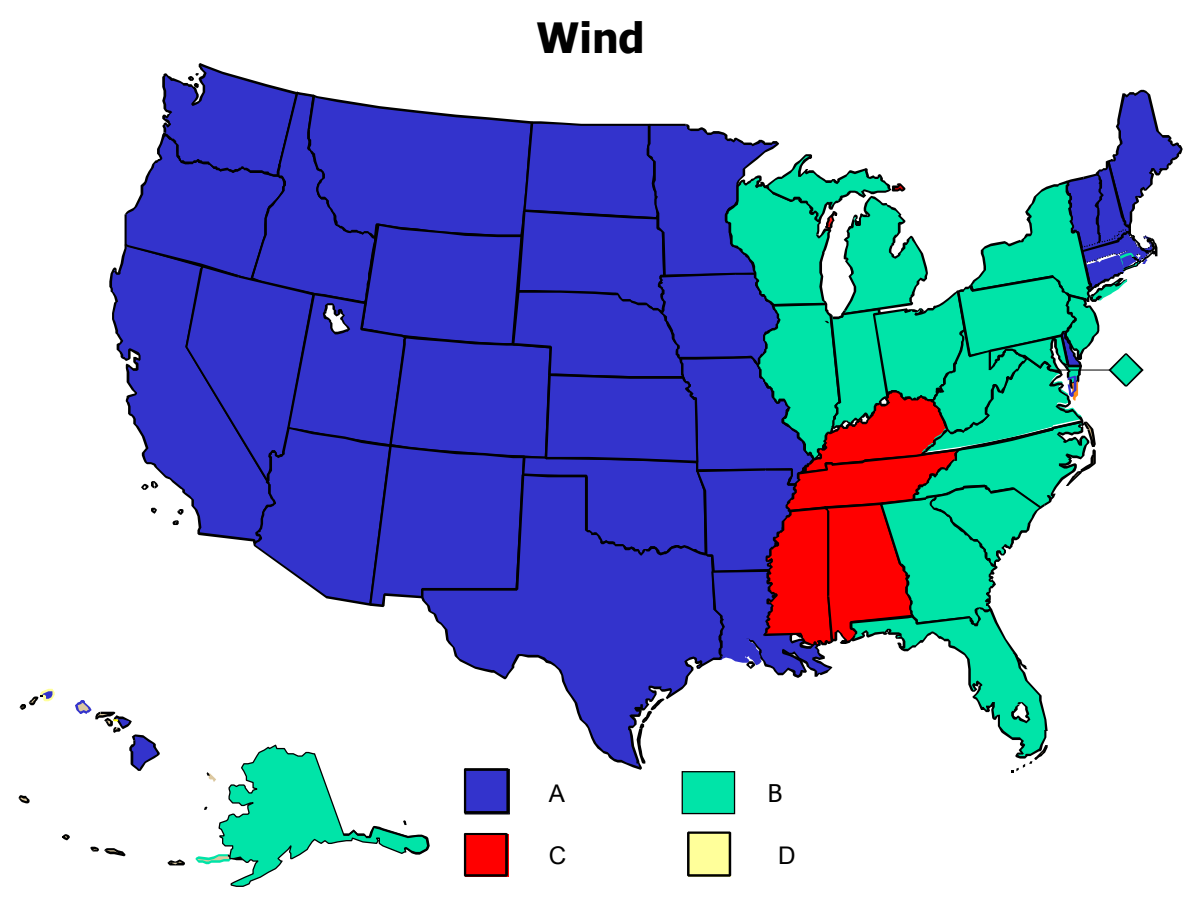

FIGURE 3.6 Regional Wind Resource Characterization

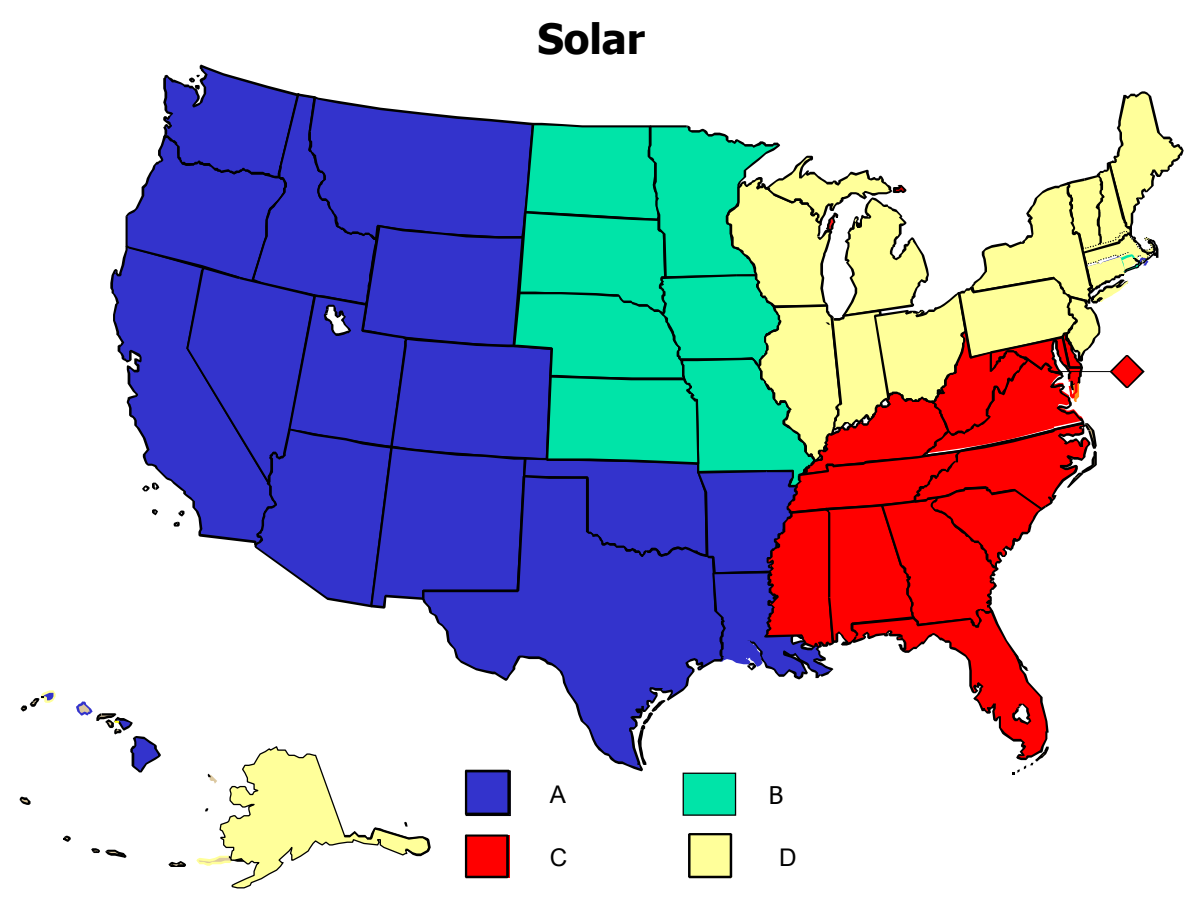

FIGURE 3.7 Regional Solar Resource Characterization 
TABLE 3.2 Maximum $\mathrm{H}_{2}$ That Can Be Generated for Centralized Electrolysis

\begin{tabular}{ll}
\hline \multicolumn{1}{c}{ U.S. Census Division } & $\begin{array}{c}\text { Maximum } \mathbf{H}_{\mathbf{2}} \text { Generated from } \\
\text { Centralized Electrolysis (Quads) }\end{array}$ \\
\hline New England & 0.027 \\
Middle Atlantic & 0.019 \\
East North Central & 0.055 \\
West North Central & 0.062 \\
South Atlantic & 0.070 \\
East South Central & 0.031 \\
West South Central & 0.062 \\
Mountain & 0.031 \\
Pacific (contiguous states only) & 0.047 \\
Alaska & 0.010 \\
Pacific & 0.001 \\
United States & 0.419 \\
\hline
\end{tabular}

TABLE 3.3 Distributed Production Share of Total $\mathbf{H}_{2}$ Production by Region

\begin{tabular}{lrrc}
\hline \multicolumn{1}{c}{ Region } & $\begin{array}{r}\mathbf{2 0 2 0} \\
\mathbf{( \% )}\end{array}$ & $\begin{array}{c}\mathbf{2 0 3 0} \\
\mathbf{( \% )}\end{array}$ & $\begin{array}{c}\mathbf{2 0 4 0} \text { and 2050 } \\
\mathbf{( \% )}\end{array}$ \\
\hline New England & & & \\
Middle Atlantic & 2.3 & 6.0 & 10.0 \\
East North Central & 2.7 & 5.3 & 8.8 \\
West North Central & 4.8 & 10.3 & 17.2 \\
South Atlantic & 8.7 & 19.4 & 32.3 \\
East South Central & 5.5 & 10.6 & 17.7 \\
West South Central & 7.8 & 19.7 & 32.8 \\
Mountain & 6.3 & 11.6 & 19.4 \\
Contiguous Pacific & 10.3 & 15.9 & 26.5 \\
Alaska & 2.0 & 3.4 & 5.6 \\
Hawaii & 18.2 & 27.8 & 46.3 \\
U.S. Total & 0.0 & 14.2 & 23.7 \\
\hline
\end{tabular}


but we assume that the use of natural gas will be phased out completely (unless $\mathrm{H}_{2}$ demand is very low), which is consistent with the intent of the DOE program. Table 3.4 presents our assumptions about phasing out the use of natural gas for distributed production. The phaseout varies by each region's natural gas rating shown in Table 3.1.

The Regional $\mathrm{H}_{2}$ Model is set up so that the user can modify our assumptions about the percentage of non-metropolitan travel that is served by distributed production. It is not set up to allow the use of distributed production in metropolitan areas in the early years of FCV use. Distributed production of $\mathrm{H}_{2}$ in metropolitan areas may in fact occur, but we assume that metropolitan areas will turn to the less-expensive centrally produced $\mathrm{H}_{2}$ alternative as quickly as possible.

\subsection{CENTRALIZED PRODUCTION OF $\mathrm{H}_{2}$ BY RESOURCE FUEL AND REGION}

Once the volume of $\mathrm{H}_{2}$ produced by distributed production is estimated, the total amount of $\mathrm{H}_{2}$ produced centrally is set. The question then is what shares each resource fuel will contribute regionally.

We first estimate the volume of $\mathrm{H}_{2}$ produced by centralized electrolysis. We assume that up to, but no more than, $5 \%$ of each region's current electricity generation can be used at power plants to produce $\mathrm{H}_{2}$ relatively inexpensively and that this percentage will remain constant. But we further limit the volume generated by assuming that centralized electrolysis can be used to produce no more than $30 \%$ of the total $\mathrm{H}_{2}$ required in a region, up to the maximum of $5 \%$.

Next, using the resource characterizations presented in Section 3.2, we developed a number of "rules" or guiding assumptions that would allocate resources for centralized production of $\mathrm{H}_{2}$ across regions, time, and demand levels. (All of these rules can be changed in the model — some more easily than others.) The rules are as follows:

1. For natural gas, we assume that it will be phased out completely by 2050 , unless there is very low $\mathrm{H}_{2}$ demand. Specifically, we assume:

a. If total U.S. $\mathrm{H}_{2}$ demand is less than 0.5 Quads in any year, only natural gas and centralized electrolysis will be used (unless a region is rated a "D" on

TABLE 3.4 Natural Gas Share of Distributed $\mathrm{H}_{2}$ Production

\begin{tabular}{cccccc}
\hline $\begin{array}{c}\text { Region's } \\
\text { Natural Gas } \\
\text { Rating }\end{array}$ & $\begin{array}{c}\text { 2010 Share } \\
\text { (\%) }\end{array}$ & $\begin{array}{c}\text { 2020 Share } \\
(\%)\end{array}$ & $\begin{array}{c}\mathbf{2 0 3 0} \text { Share } \\
(\%)\end{array}$ & $\begin{array}{c}\text { 2040 Share } \\
(\%)\end{array}$ & $\begin{array}{c}\text { 2050 Share } \\
\text { (\%) }\end{array}$ \\
\hline A & 80 & 80 & 50 & 20 & 0 \\
B & 65 & 65 & 40 & 15 & 0 \\
C & 50 & 50 & 25 & 0 & 0 \\
D & 0 & 0 & 0 & 0 & 0 \\
\hline
\end{tabular}


natural gas, in which case only centralized electrolysis is used). (In the GYOW scenario, this demand level is reached by 2024, when approximately 15 million vehicles are on the road.)

b. If total U.S. $\mathrm{H}_{2}$ demand is greater than 0.5 Quads, then the assumed maximum use of natural gas in a region is as shown in Table 3.5.

2. For thermochemical water splitting using advanced high-temperature nuclear reactors, we assume that this technology will not be in use until 2030 and that its national use will be approximately $20 \%$ by 2050 . Specifically, we assume that it will provide $1 \%$ of the $\mathrm{H}_{2}$ demand in $2030,8 \%$ in 2040 , and $20 \%$ in 2050 in regions that have nuclear power and that are rated highly (" $A$ ") either for coal or renewables. If a region has nuclear power, but is not rated highly for coal or renewables, it may use $25 \%$ more nuclear power than average.

3. The model calculates the percentage of $\mathrm{H}_{2}$ produced from natural gas use and thermochemical water splitting via nuclear reactors first for each region. Coal and renewables as a whole split the difference, but according to the assumptions stated in Table 3.6.

4. Because the cost of $\mathrm{H}_{2}$ produced from the individual renewable resources will vary, we also developed estimates of the composition of the regional renewable resource estimates developed above - in other words, what percentage will be produced from biomass, wind, and solar technologies. Estimating these variables is difficult to do on a resource basis alone. Even if a region received an " $\mathrm{A}$ " rating for solar and "Bs" for wind and biomass, we should not necessarily assume that "solar" would be more extensively used in that region to produce $\mathrm{H}_{2}$ than the other two resources.

TABLE 3.5 Percent of $\mathrm{H}_{2}$ Produced Centrally from Natural Gas where National Demand for $\mathrm{H}_{2}>0.5$ Quads in Any Year ${ }^{\mathrm{a}}$

\begin{tabular}{cccccc}
\hline $\begin{array}{c}\text { Region's } \\
\text { Natural Gas } \\
\text { Rating }\end{array}$ & $\begin{array}{c}\text { Percent } \\
\text { Production, } \\
\mathbf{2 0 1 0}\end{array}$ & $\begin{array}{c}\text { Percent } \\
\text { Production, } \\
\mathbf{2 0 2 0}\end{array}$ & $\begin{array}{c}\text { Percent } \\
\text { Production, } \\
\mathbf{2 0 3 0}\end{array}$ & $\begin{array}{c}\text { Percent } \\
\text { Production, } \\
\mathbf{2 0 4 0}\end{array}$ & $\begin{array}{c}\text { Percent } \\
\text { Production, } \\
\mathbf{2 0 5 0}\end{array}$ \\
\hline A & 95 & 80 & 40 & 20 & 0 \\
B & 90 & 70 & 30 & 15 & 0 \\
C & 80 & 60 & 20 & 0 & 0 \\
D & 0 & 0 & 0 & 0 & 0 \\
\hline
\end{tabular}

a Natural gas is also used at lower $\mathrm{H}_{2}$ demand levels, but it then is one of only two options for producing $\mathrm{H}_{2}$ centrally (see Section 3.4). 
Table 3.6 Coal and Renewables Shares once Natural Gas and Nuclear Shares Are Estimated

\begin{tabular}{cccc}
\hline $\begin{array}{c}\text { Coal } \\
\text { Rating }\end{array}$ & $\begin{array}{c}\text { Renewables } \\
\text { Rating }\end{array}$ & $\begin{array}{c}\text { Coal Share } \\
(\%)\end{array}$ & $\begin{array}{c}\text { Renewables } \\
\text { Share (\%) }\end{array}$ \\
\hline \multirow{2}{*}{ A } & A & 50 & 50 \\
& B & 62.5 & 37.5 \\
& C & 75 & 25 \\
B & A & 37.5 & 62.5 \\
& B & 50 & 50 \\
& C & 62.5 & 37.5 \\
C & A & 25 & 75 \\
& B & 37.5 & 62.5 \\
& C & 50 & 50 \\
$\mathrm{D}^{\mathrm{a}}$ & $\mathrm{A} / \mathrm{B} / \mathrm{C}$ & 0 & 100 \\
\hline
\end{tabular}

a There are no regions that are " $D$ " in both coal and renewables.

Therefore, we turned to the EIA's AEO 2003, which contains projections of the volume of renewables by type used in electricity generation and end-use sector energy to 2025 by electricity market module (EMM) regions (EIA 2003a). The EMM regions are not the same as the U.S. Census Divisions. Still, we used the projections for the EMM regions to develop estimates of renewables use by type (on a percentage basis) in U.S. Census Divisions in 2025 (see Table 3.7). We then used these regional percentage estimates throughout the entire period of this analysis. Again, these percentage estimates are applied to the total renewables percent determined as discussed in "rule 3" above.

\subsection{FINAL $\mathrm{H}_{2}$ PRODUCTION ESTIMATES BY REGION FOR THE GYOW SCENARIO}

The distributed and centralized production estimates were then combined, all on a regional basis. The final estimates for the United States are shown in Table 3.8 and Figure 3.8. Table 3.9 presents the percentage of each resource used to produce $\mathrm{H}_{2}$ in each region by year. Figure 3.9 presents the regional results for 2050 . 
TABLE 3.7 Biomass, Wind, and Solar Shares of Renewables

\begin{tabular}{lccc}
\hline \multicolumn{1}{c}{ U.S. Census Division } & $\begin{array}{c}\text { Biomass } \\
\text { Share (\%) }\end{array}$ & $\begin{array}{c}\text { Wind Share } \\
\mathbf{( \% )}\end{array}$ & $\begin{array}{c}\text { Solar Share } \\
\text { (\%) }\end{array}$ \\
\hline New England & & & \\
Middle Atlantic & 82.8 & 14.6 & 2.6 \\
East North Central & 86.4 & 12.1 & 1.5 \\
West North Central & 85.2 & 14.1 & 0.7 \\
South Atlantic & 63.5 & 33.8 & 2.7 \\
East South Central & 92.8 & 5.1 & 2.1 \\
West South Central & 91.1 & 6.3 & 2.6 \\
Mountain & 38.1 & 58.7 & 3.2 \\
Pacific (contiguous states only) & 15.6 & 78.8 & 5.6 \\
Alaska & 29.7 & 63.7 & 6.6 \\
Pacific & 66.5 & 30.4 & 3.1 \\
\hline
\end{tabular}

TABLE 3.8 Final Estimate of $\mathrm{H}_{2}$ Production in the United States for GYOW Scenario

\begin{tabular}{|c|c|c|c|c|c|c|c|c|c|c|}
\hline \multirow[b]{2}{*}{ Year } & \multicolumn{2}{|c|}{$\begin{array}{c}\text { Distributed Production } \\
\text { (Quads) }\end{array}$} & \multicolumn{8}{|c|}{ Centralized Production (Quads) } \\
\hline & $\begin{array}{c}\text { Distributed } \\
\text { Natural Gas } \\
\end{array}$ & $\begin{array}{l}\text { Distributed } \\
\text { Electrolysis }\end{array}$ & Electrolysis & Natural Gas & Coal & Biomass & Wind & Solar & Nuclear & Total \\
\hline 2010 & 0.00 & 0.00 & 0.000032 & 0.000073 & 0.000000 & 0.000000 & 0.000000 & 0.000000 & 0.000000 & 0.000105 \\
\hline 2020 & 0.004 & 0.002 & 0.035 & 0.075 & 0.000 & 0.000 & 0.000 & 0.000 & 0.000 & 0.116 \\
\hline 2030 & 0.085 & 0.132 & 0.396 & 0.438 & 0.437 & 0.396 & 0.150 & 0.018 & 0.014 & 2.065 \\
\hline 2040 & 0.104 & 0.700 & 0.412 & 0.423 & 1.161 & 1.076 & 0.403 & 0.049 & 0.257 & 4.585 \\
\hline 2050 & 0.000 & 0.996 & 0.412 & 0.000 & 1.501 & 1.354 & 0.535 & 0.063 & 0.812 & 5.673 \\
\hline & \multicolumn{2}{|c|}{$\begin{array}{c}\text { Distributed Production } \\
(\%)\end{array}$} & \multicolumn{8}{|c|}{ Centralized Production ( \%) } \\
\hline Year & $\begin{array}{c}\text { Distributed } \\
\text { Natural Gas } \\
\end{array}$ & $\begin{array}{l}\text { Distributed } \\
\text { Electrolysis }\end{array}$ & Electrolysis & Natural Gas & Coal & Biomass & Wind & Solar & Nuclear & Total \\
\hline 2010 & 0.0 & 0.0 & 30.0 & 69.8 & 0.0 & 0.1 & 0.1 & 0.0 & 0.0 & 100.0 \\
\hline 2020 & 3.4 & 1.8 & 30.0 & 64.6 & 0.0 & 0.1 & 0.1 & 0.0 & 0.0 & 100.0 \\
\hline 2030 & 4.1 & 6.4 & 19.2 & 21.2 & 21.1 & 19.2 & 7.2 & 0.9 & 0.7 & 100.0 \\
\hline 2040 & 2.3 & 15.3 & 9.0 & 9.2 & 25.3 & 23.5 & 8.8 & 1.1 & 5.6 & 100.0 \\
\hline 2050 & 0.0 & 17.6 & 7.3 & 0.0 & 26.5 & 23.9 & 9.4 & 1.1 & 14.3 & 100.0 \\
\hline
\end{tabular}




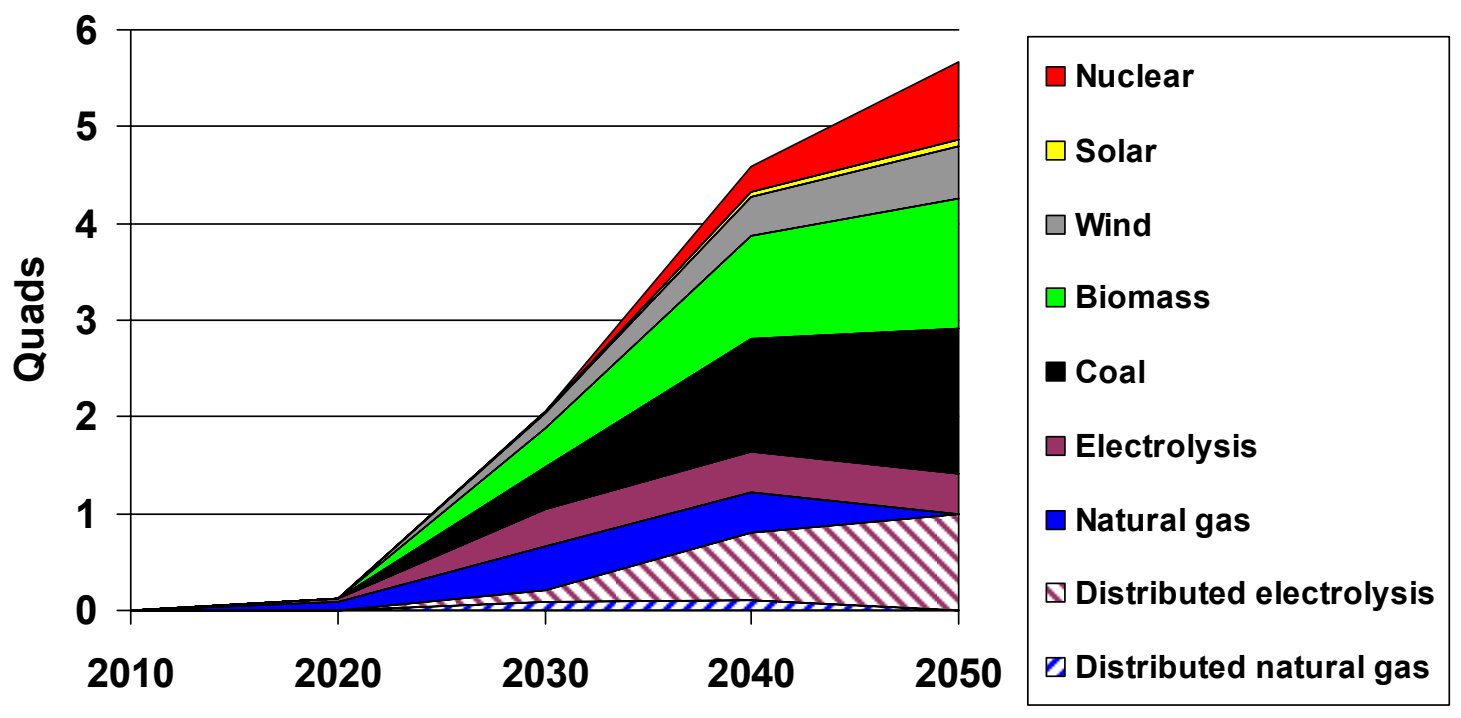

FIGURE 3.8 Resource Fuels Used to Produce $\mathrm{H}_{2}$ in GYOW: United States

TABLE 3.9 Source of $\mathrm{H}_{2}$ in GYOW Scenario by Region

\begin{tabular}{|c|c|c|c|c|c|c|c|c|c|c|c|}
\hline \multirow[b]{2}{*}{ Region } & & \multicolumn{2}{|c|}{$\begin{array}{c}\text { Distributed Production } \\
(\%)\end{array}$} & \multicolumn{7}{|c|}{ Centralized Production (\%) } & \multirow[b]{2}{*}{$\begin{array}{r}\text { Total } \\
\text { Quads } \\
\end{array}$} \\
\hline & & $\begin{array}{l}\text { Natural } \\
\text { Gas }\end{array}$ & Electrolysis & Electrolysis & $\begin{array}{l}\text { Natural } \\
\text { Gas }\end{array}$ & Coal & Biomass & Wind & Solar & Nuclear & \\
\hline \multicolumn{12}{|c|}{ NEW ENGLAND } \\
\hline & 2010 & 0.0 & 0.0 & 30.0 & 70.0 & 0.0 & 0.0 & 0.0 & 0.0 & 0.0 & 0.00001 \\
\hline & 2020 & 1.1 & 1.1 & 30.0 & 67.7 & 0.0 & 0.0 & 0.0 & 0.0 & 0.0 & 0.006 \\
\hline & 2030 & 1.5 & 4.5 & 27.3 & 13.3 & 0.0 & 43.5 & 7.7 & 1.3 & 0.8 & 0.10 \\
\hline & 2040 & 0.0 & 10.1 & 12.3 & 0.0 & 0.0 & 57.9 & 10.2 & 1.8 & 7.8 & 0.22 \\
\hline & 2050 & 0.0 & 10.1 & 9.9 & 0.0 & 0.0 & 49.7 & 8.8 & 1.5 & 20.0 & 0.27 \\
\hline \multicolumn{12}{|c|}{ MIDDLE ATLANTIC } \\
\hline & 2010 & 0.0 & 0.0 & 30.0 & 70.0 & 0.0 & 0.0 & 0.0 & 0.0 & 0.0 & 0.00001 \\
\hline & 2020 & 1.8 & 1.0 & 30.0 & 67.3 & 0.0 & 0.0 & 0.0 & 0.0 & 0.0 & 0.013 \\
\hline & 2030 & 2.1 & 3.2 & 8.6 & 25.8 & 37.1 & 19.2 & 2.7 & 0.3 & 0.9 & 0.23 \\
\hline & 2040 & 1.3 & 7.5 & 3.9 & 13.1 & 42.0 & 21.8 & 3.1 & 0.4 & 7.0 & 0.51 \\
\hline & 2050 & 0.0 & 8.8 & 3.1 & 0.0 & 44.0 & 22.8 & 3.2 & 0.4 & 17.6 & 0.64 \\
\hline \multicolumn{12}{|c|}{ EAST NORTH CENTRAL } \\
\hline & 2010 & 0.0 & 0.0 & 30.0 & 70.0 & 0.0 & 0.0 & 0.0 & 0.0 & 0.0 & 0.00002 \\
\hline & 2020 & 3.9 & 1.0 & 30.0 & 65.2 & 0.0 & 0.0 & 0.0 & 0.0 & 0.0 & 0.018 \\
\hline & 2030 & 5.2 & 5.2 & 17.0 & 29.1 & 21.4 & 18.3 & 3.0 & 0.2 & 0.7 & 0.33 \\
\hline & 2040 & 3.4 & 13.7 & 7.7 & 15.0 & 27.1 & 23.0 & 3.8 & 0.2 & 6.0 & 0.73 \\
\hline & 2050 & 0.0 & 17.2 & 6.2 & 0.0 & 30.7 & 26.1 & 4.3 & 0.2 & 15.3 & 0.90 \\
\hline \multicolumn{12}{|c|}{ WEST NORTH CENTRAL } \\
\hline & 2010 & 0.0 & 0.0 & 30.0 & 70.0 & 0.0 & 0.0 & 0.0 & 0.0 & 0.0 & 0.00001 \\
\hline & 2020 & 5.6 & 3.0 & 30.0 & 61.3 & 0.0 & 0.0 & 0.0 & 0.0 & 0.0 & 0.009 \\
\hline & 2030 & 7.8 & 11.6 & 30.0 & 15.2 & 13.1 & 13.9 & 7.4 & 0.6 & 0.5 & 0.16 \\
\hline & 2040 & 4.8 & 27.4 & 17.6 & 7.5 & 14.5 & 15.3 & 8.1 & 0.7 & 4.0 & 0.35 \\
\hline & 2050 & 0.0 & 32.3 & 14.2 & 0.0 & 16.0 & 17.0 & 9.0 & 0.7 & 10.7 & 0.44 \\
\hline
\end{tabular}


TABLE 3.9 (Cont.)

\begin{tabular}{|c|c|c|c|c|c|c|c|c|c|c|c|}
\hline \multirow[b]{2}{*}{ Region } & & \multicolumn{2}{|c|}{$\begin{array}{c}\text { Distributed Production } \\
(\%)\end{array}$} & \multicolumn{7}{|c|}{ Centralized Production (\%) } & \multirow[b]{2}{*}{$\begin{array}{l}\text { Total } \\
\text { Quads } \\
\end{array}$} \\
\hline & & $\begin{array}{l}\text { Natural } \\
\text { Gas }\end{array}$ & Electrolysis & Electrolysis & $\begin{array}{c}\text { Natural } \\
\text { Gas }\end{array}$ & Coal & Biomass & Wind & Solar & Nuclear & \\
\hline \multicolumn{12}{|c|}{ SOUTH ATLANTIC } \\
\hline & 2010 & 0.0 & 0.0 & 30.0 & 70.0 & 0.0 & 0.0 & 0.0 & 0.0 & 0.0 & 0.00002 \\
\hline & 2020 & 2.7 & 2.7 & 30.0 & 64.5 & 0.0 & 0.0 & 0.0 & 0.0 & 0.0 & 0.023 \\
\hline & 2030 & 2.7 & 8.0 & 17.1 & 14.5 & 28.6 & 26.5 & 1.5 & 0.6 & 0.7 & 0.41 \\
\hline & 2040 & 0.0 & 17.7 & 7.7 & 0.0 & 34.3 & 31.9 & 1.8 & 0.7 & 6.0 & 0.91 \\
\hline & 2050 & 0.0 & 17.7 & 6.2 & 0.0 & 30.4 & 28.2 & 1.6 & 0.6 & 15.2 & 1.13 \\
\hline
\end{tabular}

EAST SOUTH CENTRAL

$\begin{array}{rrrrrrrrrrl}2010 & 0.0 & 0.0 & 30.0 & 70.0 & 0.0 & 0.0 & 0.0 & 0.0 & 0.0 & 0.00001 \\ 2020 & 5.0 & 2.7 & 30.0 & 62.2 & 0.0 & 0.0 & 0.0 & 0.0 & 0.0 & 0.008 \\ 2030 & 7.9 & 11.8 & 21.9 & 17.5 & 25.2 & 13.8 & 0.9 & 0.4 & 0.6 & 0.14 \\ 2040 & 4.9 & 27.9 & 9.9 & 8.6 & 27.6 & 15.1 & 1.0 & 0.4 & 4.6 & 0.31 \\ 2050 & 0.0 & 32.8 & 8.0 & 0.0 & 29.6 & 16.2 & 1.1 & 0.5 & 11.8 & 0.39\end{array}$

WEST SOUTH CENTRAL

$\begin{array}{rrrrrrrrrrl}2010 & 0.0 & 0.0 & 30.0 & 70.0 & 0.0 & 0.0 & 0.0 & 0.0 & 0.0 & 0.00001 \\ 2020 & 5.0 & 1.3 & 30.0 & 63.7 & 0.0 & 0.0 & 0.0 & 0.0 & 0.0 & 0.014 \\ 2030 & 5.8 & 5.8 & 24.8 & 25.4 & 14.1 & 21.3 & 1.5 & 0.6 & 0.6 & 0.25 \\ 2040 & 3.9 & 15.5 & 11.2 & 13.9 & 18.7 & 28.5 & 2.0 & 0.8 & 5.6 & 0.56 \\ 2050 & 0.0 & 19.4 & 9.0 & 0.0 & 21.5 & 32.6 & 2.2 & 0.9 & 14.3 & 0.69\end{array}$

MOUNTAIN

$\begin{array}{rrrrrrrrrrl}2010 & 0.0 & 0.0 & 30.0 & 70.0 & 0.0 & 0.0 & 0.0 & 0.0 & 0.0 & 0.00001 \\ 2020 & 6.7 & 3.6 & 30.0 & 59.7 & 0.0 & 0.0 & 0.0 & 0.0 & 0.0 & 0.008 \\ 2030 & 6.4 & 9.6 & 22.7 & 18.4 & 21.5 & 3.4 & 16.9 & 1.2 & 0.0 & 0.14 \\ 2040 & 4.0 & 22.6 & 10.2 & 9.5 & 26.9 & 4.2 & 21.2 & 1.5 & 0.0 & 0.30 \\ 2050 & 0.0 & 26.5 & 8.3 & 0.0 & 32.6 & 5.1 & 25.7 & 1.8 & 0.0 & 0.38\end{array}$

\section{CONTIGUOUS PACIFIC}

$\begin{array}{rrrrrrrrrrl}2010 & 0.0 & 0.0 & 30.0 & 70.0 & 0.0 & 0.0 & 0.0 & 0.0 & 0.0 & 0.00002 \\ 2020 & 1.3 & 0.7 & 30.0 & 68.0 & 0.0 & 0.0 & 0.0 & 0.0 & 0.0 & 0.017 \\ 2030 & 1.3 & 2.0 & 16.2 & 24.1 & 13.9 & 12.3 & 26.5 & 2.8 & 0.8 & 0.30 \\ 2040 & 0.8 & 4.8 & 7.3 & 13.1 & 16.8 & 14.9 & 32.0 & 3.3 & 7.0 & 0.66 \\ 2050 & 0.0 & 5.6 & 5.9 & 0.0 & 17.7 & 15.8 & 33.8 & 3.5 & 17.7 & 0.81\end{array}$

ALASKA

$\begin{array}{rrrrrrrrrrl}2010 & 0.0 & 0.0 & 30.0 & 70.0 & 0.0 & 0.0 & 0.0 & 0.0 & 0.0 & 0.00000 \\ 2020 & 11.8 & 6.4 & 30.0 & 51.8 & 0.0 & 0.0 & 0.0 & 0.0 & 0.0 & 0.000 \\ 2030 & 11.1 & 16.7 & 30.0 & 12.7 & 18.5 & 7.4 & 3.4 & 0.3 & 0.0 & 0.00 \\ 2040 & 6.9 & 39.4 & 30.0 & 3.6 & 12.6 & 5.0 & 2.3 & 0.2 & 0.0 & 0.01 \\ 2050 & 0.0 & 46.3 & 30.0 & 0.0 & 14.8 & 5.9 & 2.7 & 0.3 & 0.0 & 0.01\end{array}$

HAWAII

\begin{tabular}{rrrrrrrrrrl}
2010 & 0.0 & 0.0 & 30.0 & 0.0 & 0.0 & 46.5 & 21.3 & 2.2 & 0.0 & 0.00000 \\
2020 & 0.0 & 0.0 & 30.0 & 0.0 & 0.0 & 46.5 & 21.3 & 2.2 & 0.0 & 0.000 \\
2030 & 0.0 & 14.2 & 19.3 & 0.0 & 0.0 & 44.1 & 20.2 & 2.1 & 0.0 & 0.01 \\
2040 & 0.0 & 23.7 & 8.7 & 0.0 & 0.0 & 44.9 & 20.5 & 2.1 & 0.0 & 0.01 \\
2050 & 0.0 & 23.7 & 7.0 & 0.0 & 0.0 & 46.0 & 21.0 & 2.2 & 0.0 & 0.02 \\
\hline
\end{tabular}




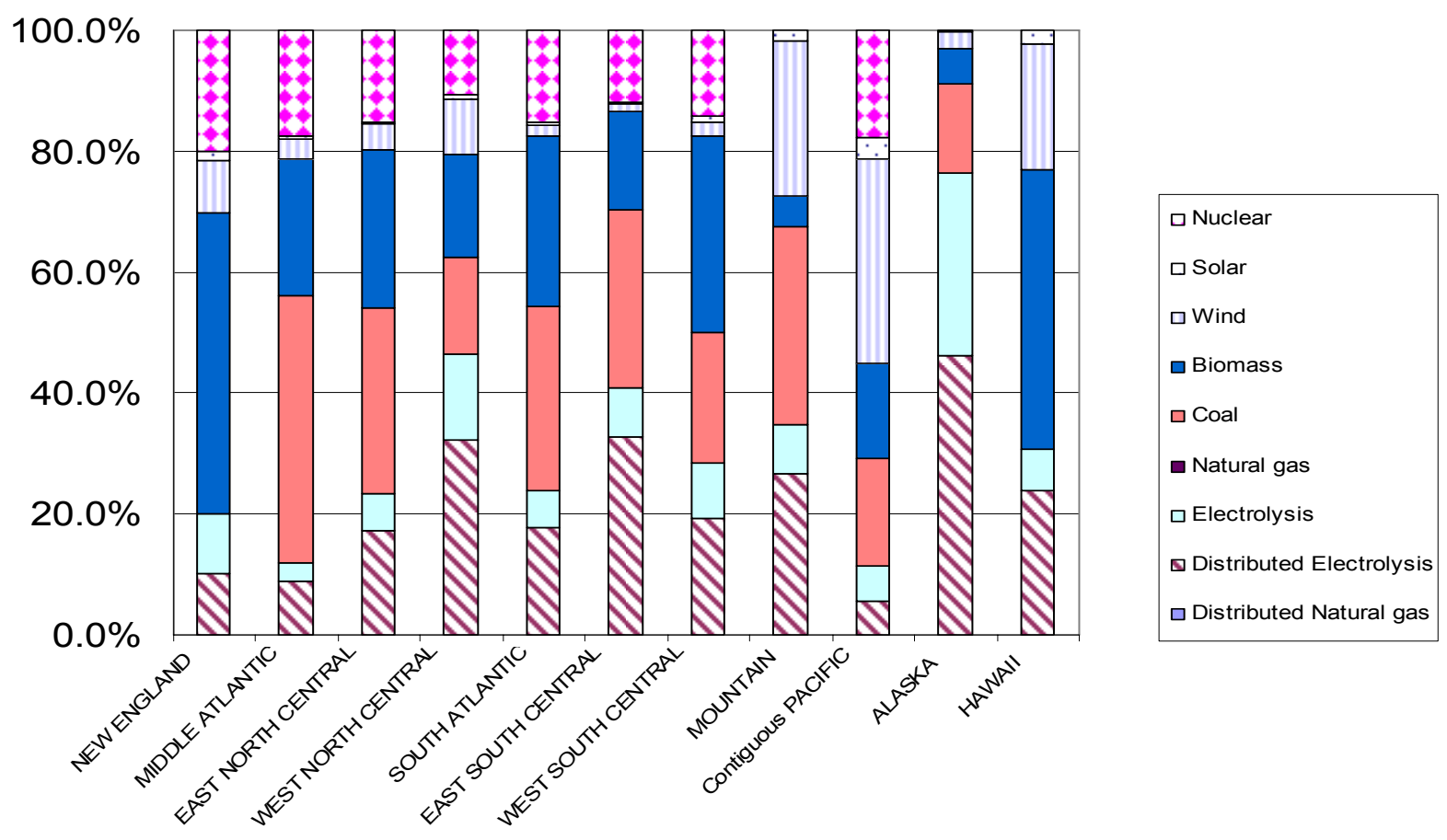

FIGURE 3.9 Source of $\mathrm{H}_{2}$ in 2050 in GYOW Scenario by Region 


\section{HYDROGEN COST}

\subsection{OVERVIEW}

In this section, we discuss how we developed $\mathrm{H}_{2}$ cost estimates by region and over time for the GYOW scenario. Several general comments need to be made before discussing the details of the analysis.

1. Our cost estimates are just that: cost estimates. They are not price estimates, which are market-driven. Our cost estimates implicitly include some profit (i.e., capital costs include an expected rate of return). However, mark-up for retail profit on the sale of $\mathrm{H}_{2}$ is not included. Finally, taxes are not included.

2. The principal source used to generate the cost estimates is a report by SFA Pacific (SFA), Inc. (2002). This reference was specifically used to develop estimates for the production of $\mathrm{H}_{2}$ from the following technologies:

- Steam reforming of natural gas or steam methane reforming (SMR),

- Coal gasification,

- Electrolysis,

- Biomass gasification, and

- Distributed production technologies (natural gas reforming and electrolysis in volumes compatible with demand at refilling stations in non-metropolitan locations).

3. Energy cost projections to 2025 for electricity, coal, and natural gas used in both the centralized and distributed production cost analysis are from EIA's AEO 2003 documentation (EIA 2003a). (AEO price projections are treated as costs in the production of $\mathrm{H}_{2}$.) The 2020 to 2025 cost trends were extrapolated to 2050. AEO national average energy costs and extrapolations are summarized in Table 4.1. However, it is AEO's regional cost projections (and extrapolations from them consistent with the extrapolations shown in Table 4.1) that are used in this analysis.

4. Biomass resource costs were derived from biomass supply curves developed by ORNL and available by state (ORNL 2003). Regional estimates were calculated by weighting the state-level volume and price estimates. (The ORNL price estimates are treated as costs in the production of $\mathrm{H}_{2}$.) The regional biomass resource estimates thus calculated are presented in Table 4.2. 
TABLE 4.1 Costs of Input Energy (Natural Gas, Coal, and Electricity) to Produce Hydrogen, National Averages

\begin{tabular}{|c|c|c|c|c|c|c|c|c|}
\hline $\begin{array}{l}\text { Sector and } \\
\text { Source }\end{array}$ & 2000 & 2010 & 2020 & 2025 & 2030 & 2040 & 2050 & Comments \\
\hline $\begin{array}{l}\text { Natural Gas Price, } \\
\$ / \mathrm{mmBTU}\end{array}$ & 5.59 & 5.03 & 5.35 & 5.60 & 5.92 & 6.57 & 7.23 & $\begin{array}{l}\text { Extrapolated } \\
\text { from 2021-2025 }\end{array}$ \\
\hline $\begin{array}{l}\text { Coal Price, } \\
\$ / \mathrm{mmBTU}\end{array}$ & 1.24 & 1.18 & 1.13 & 1.12 & 1.10 & 1.08 & 1.06 & $\begin{array}{l}\text { Extrapolated } \\
\text { from 2021-2025 }\end{array}$ \\
\hline $\begin{array}{l}\text { Coal Price Used } \\
\text { for } \mathrm{H}_{2} \text { Cost } \\
\text { Model, } \$ / \mathrm{mmBTU}\end{array}$ & 1.24 & 1.18 & 1.13 & 1.13 & 1.13 & 1.13 & 1.13 & $\begin{array}{l}\text { Held constant } \\
\text { after } 2020\end{array}$ \\
\hline $\begin{array}{l}\text { Electricity Price, } \\
\$ / \text { kwh }\end{array}$ & 0.069 & 0.063 & 0.066 & .067 & 0.069 & 0.071 & 0.073 & $\begin{array}{l}\text { Extrapolated } \\
\text { from 2021-2025 }\end{array}$ \\
\hline
\end{tabular}

TABLE 4.2 Costs of Input Energy (Biomass) to Produce Hydrogen ${ }^{a}$

\begin{tabular}{lcc}
\hline \multicolumn{1}{c}{ Region } & $\begin{array}{c}\text { Median Price } \\
\text { (\$/dry ton) } \\
\text { in 2010 }\end{array}$ & $\begin{array}{c}\text { Median Price } \\
\text { (\$/dry ton) } \\
\text { in 2050 }\end{array}$ \\
\hline New England & & \\
Middle Atlantic & 30.03 & 23.78 \\
East North Central & 31.53 & 30.02 \\
West North Central & 29.99 & 26.84 \\
South Atlantic & 29.85 & 24.75 \\
East South Central & 27.97 & 24.25 \\
West South Central & 28.57 & 25.68 \\
Mountain & 30.55 & 25.88 \\
Pacific (contiguous states only) & 31.01 & 24.38 \\
Alaska & 29.08 & 23.03 \\
Pacific & NA (assume Pacific) \\
\hline
\end{tabular}

${ }^{a}$ Median prices gradually decrease from 2010 to 2050 values.

We assume that these estimates apply to 2010 and are gradually lowered over time by as much as $20 \%$ by 2050 , although there are regional variations. The 2050 estimates are also presented in Table 4.2.

5. Because the volume of $\mathrm{H}_{2}$ produced and moved affects final costs and because the Regional $\mathrm{H}_{2}$ Model was designed to allow alternative demand levels to be input, our cost estimates are generally developed for the President's Hydrogen Fuel Initiative scenario (100\% penetration of FCVs). They are then input to the Regional $\mathrm{H}_{2}$ Model, in which the demand level of any given scenario determines the costs finally estimated. The only exception is that the cost 
estimates for distributed production were developed for the GYOW scenario. For demand levels higher than those of GYOW, the model assumes the distributed production cost estimates of the GYOW scenario.

6. Although we disaggregated the Pacific region into three regions (Contiguous Pacific, Alaska, and Hawaii) for $\mathrm{H}_{2}$ demand and production estimates, we generally only developed cost estimates for the Contiguous Pacific region and used those costs for Alaska and Hawaii. However, there are exceptions (e.g., distributed production of $\mathrm{H}_{2}$ using natural gas in Alaska).

7. Finally, our cost estimates are derived from several sources. We characterize our final cost estimates as being in 2001 dollars.

\subsection{CENTRALIZED HYDROGEN PRODUCTION COST ESTIMATES}

\subsubsection{Production Technology}

The cost analysis for each centralized production technology is based on a benchmark capacity of $150,000 \mathrm{~kg} /$ day, as utilized by SFA (SFA Pacific, Inc. 2002). SFA presented cost elements that would allow the costs for plants of various sizes to be estimated, but we chose to assume the same plant size for all centralized production technologies.

We assumed process efficiency improvements for all technologies. Initial values used were from the SFA report, improving toward U.S. DOE $\mathrm{H}_{2}$ program efficiency goals for various technologies during the analysis period (DOE 2003). Principal process cost elements for one technology option - coal gasification - are listed below. These are representative of the approach used by SFA Pacific.

- Coal handling and preparation,

- Coal gasifiers (Texaco process),

- Air separators,

- $\mathrm{CO}_{2}$ removal,

- Sulfur recovery,

- $\mathrm{H}_{2}$ refrigeration for liquefaction,

- $\mathrm{H}_{2}$ gas storage, and

- $\mathrm{H}_{2}$ dispensing.

In addition to these sub-processes, indirect costs were considered by SFA Pacific - these are listed as percentage multipliers:

- General facilities,

- Engineering and permitting,

- Contingencies, and

- Working capital. 
Estimates of the cost to produce $\mathrm{H}_{2}$ include a capital amortization factor (18\% of total capital) and operating cost allowance. The production of $\mathrm{H}_{2}$ is capital cost intensive, but the capital costs vary by a factor of four or more among the technologies, which results in the numerical multipliers causing a large variation in the indirect cost elements of the alternative technologies. We altered the SFA multipliers to make the capital cost values of the indirect costs similar among the technologies.

Similar breakdowns in cost elements by major process sub-element are used to determine the cost of producing $\mathrm{H}_{2}$ through steam reforming of natural gas, biomass gasification, and electrolysis. Our analysis allowed for limited reductions in the cost of process equipment. The cost models include $\mathrm{CO}_{2}$ separation, but they do not include sequestration. For coal, a 20\% multiplier was applied to the derived costs to account for carbon sequestration. Process characteristics are summarized in Table 4.3.

The final production cost estimates for each region for natural gas, coal, and biomass are presented in Appendix A (Tables A.1-A.3). Table A.4 presents the cost of producing $\mathrm{H}_{2}$ centrally from electrolysis. This cost is assumed to be the same for all regions. The Regional $\mathrm{H}_{2}$ Model can accommodate the input of alternative regional estimates. We did not have time and/or satisfactory production process characterization to develop cost estimates for $\mathrm{H}_{2}$ production from wind, solar, and nuclear sources. As placeholders, we assumed that the cost of wind energy for $\mathrm{H}_{2}$ production in each region was $90 \%$ that of the region's biomass cost, the cost of solar energy for $\mathrm{H}_{2}$ production was $110 \%$ of the region's biomass cost, and that the cost of nuclear energy for $\mathrm{H}_{2}$ production would be the same as that of biomass. These placeholders can be updated.

\subsubsection{Delivery and Dispensing Costs: National Averages}

SFA developed cost estimates for the delivery of $\mathrm{H}_{2}$ provided by liquefied (refrigerated) tanker, pressurized tank (tube trailer), and pipeline (SFA Pacific, Inc., 2002). SFA's estimates are presented in Table 4.4. The SFA estimates are based on assumptions about (1) pipeline construction cost and length and (2) numbers of tube and refrigerated trailers. The report indicates that these assumptions were generated on the basis of regional conditions in the northeastern United States. However, no variation was applied to reflect other regional conditions (e.g., differences in transport differences or construction cost).

In our analysis, we assumed that only liquefied $\mathrm{H}_{2}$ tankers and pipelines would be used to deliver $\mathrm{H}_{2}$. We assumed that liquefied $\mathrm{H}_{2}$ tankers would be used initially (or for very low demand), and then, as production volume grows, a shift would occur from liquefied $\mathrm{H}_{2}$ tanker to pipeline. This assumption applies to all centralized production technologies except natural gas, because the use of natural gas is eventually phased out. Hydrogen produced from centralized production plants using natural gas is assumed to be delivered by liquefied $\mathrm{H}_{2}$ tanker. 
TABLE 4.3 Process Characteristics Summary

\section{- Air Separation Unit (used for all gasifiers)}

The air separation unit creates oxygen from the air. The amount of oxygen needed depends upon the feedstock.

Biomass: $\quad 0.8$ tons $\mathrm{O}_{2}$ per ton of biomass (dry basis), $0.37 \mathrm{kWh} / \mathrm{kg} \mathrm{O}_{2}$

Coal and Refinery Residue: $\quad 1.0$ tons of $\mathrm{O}_{2}$ per ton of coal (dry basis), $0.40 \mathrm{kWh} / \mathrm{kg} \mathrm{O}_{2}$

Petroleum Coke: $\quad 1.05$ tons $\mathrm{O}_{2}$ per ton of dry feed, $0.40 \mathrm{kWh} / \mathrm{kg} \mathrm{O}_{2}$

- Biomass Gasifier: All biomass gasifiers are assumed to consume $15 \%$ of the input biomass to dry the remaining $85 \%$ for further processing. The gasifier then converts the raw, dry biomass to synthesis gas (a mixture of carbon monoxide and hydrogen). All biomass gasifiers are assumed to operate at $51 \%$ throughput efficiency, increasing to $61 \%$ by 2050 (fuel input to syngas output, LHV basis, not counting electric inputs).

- Coal Gasifier: All coal gasifiers are assumed to operate at $64 \%$ throughput efficiency (dry coal to syngas, LHV, not counting electric inputs).

CO Shift Reactors: All of the CO shift reactors act to convert the $\mathrm{CO}$ fraction produced in the gasifier to hydrogen and $\mathrm{CO}_{2}$. All operate at approximately the same throughput efficiency (exclusive of electric input).

\section{Energy Resource}

- Biomass

- Refinery Residue

- Coal

- Petroleum Coke
Shift Reactor Throughput Efficiency (\%) (not including electricity use)

89.4

88.8

87.9

87.3

Electrolysis: All electrolysis processes are assumed to operate at a $60 \%$ increasing to $75 \%$ electricity-to-hydrogen efficiency ([LHV] basis) and to produce by-product oxygen at a mass rate of $8: 1$ to hydrogen.

Reforming: Steam methane reforming is used to produce hydrogen directly from natural gas at a throughput efficiency of $78 \%$ increasing to $80 \%$, exclusive of electric inputs.

Hydrogen Compression: In most cases, it is necessary to compress the hydrogen produced in the electrolyzers, reformers, and shift reactors so that it can be efficiently transported.

Process

Electrolysis

Steam-Methane Reformer $\quad 30$

Biomass Gasification $\quad 30$

Coal and Coke Gasification $\quad 75$

Petroleum Residue Gasification $\quad 80$

Transport Mode

Pipeline

Tube Truck
Discharge Pressure

(atmospheres [atm])

Pressure (atm)

75

215 
TABLE 4.4 $\mathrm{H}_{2}$ Delivery and Dispensing Costs (\$/GGE)

\begin{tabular}{|c|c|c|c|c|c|c|}
\hline \multirow[b]{2}{*}{ Item } & \multicolumn{2}{|c|}{ Pipeline } & \multicolumn{2}{|c|}{ Liquid Tanker } & \multicolumn{2}{|c|}{ Tube Trailer } \\
\hline & Delivery & Dispensing & Delivery & Dispensing & Delivery & Dispensing \\
\hline SFA & 2.73 & 0.99 & 0.17 & 1.18 & 1.94 & 0.93 \\
\hline \multicolumn{7}{|c|}{ Regional $\mathrm{H}_{2}$ Model } \\
\hline 2010 & NA & NA & 0.15 & 1.13 & \multicolumn{2}{|c|}{ Not estimated separately } \\
\hline 2020 & 1.57 & 0.83 & 0.15 & 0.91 & \multicolumn{2}{|c|}{ Not estimated separately } \\
\hline 2030 & 0.40 & 0.72 & 0.15 & 0.86 & \multicolumn{2}{|c|}{ Not estimated separately } \\
\hline 2040 & 0.14 & 0.61 & 0.15 & 0.72 & \multicolumn{2}{|c|}{ Not estimated separately } \\
\hline 2050 & 0.12 & 0.44 & 0.15 & 0.52 & \multicolumn{2}{|c|}{ Not estimated separately } \\
\hline
\end{tabular}

We reduced the delivery and dispensing cost of both pathways, assuming technological improvement over time. For pipelines, we also reduced SFA's estimates to account for the following:

- The assumed SFA Pacific transport distance of $600 \mathrm{~km}$ and $18 \%$ capital charges appeared high.

- As production volume grows, it was assumed that capital costs for old pipelines would be amortized, existing lines would be converted, and transport distances would decline as shipments increased. Therefore, transport and dispensing cost on a per-unit basis decreases with time.

Our national average delivery and dispensing cost estimates are also presented in Table 4.4. We hold the dispensing costs constant across regions.

\subsubsection{Regional Delivery Costs: Pipelines}

Once we developed the national average costs for $\mathrm{H}_{2}$ delivery, we developed estimates of regional variation in delivery costs. To estimate regional $\mathrm{H}_{2}$ pipeline delivery costs, we first estimated the average pipeline length from centralized $\mathrm{H}_{2}$ production plants in each region by weighting an assumed national average length of 250 miles by the number of Metropolitan Statistical Areas (MSAs) and Principal MSAs (PMSAs) per $10,000 \mathrm{mi}^{2}$ in a region. In effect, we assume that the greater the urban density of a region, the shorter the average pipeline length that needs to be constructed or converted. We then developed estimates of the cost of constructing these pipelines in each region and varied the costs by using known regional variations in construction costs and electricity prices (EIA 2003a, R.S. Means 2002). Ultimately, we derived a $\operatorname{cost} / \mathrm{GGE} \mathrm{H}_{2}$ delivered for each region.

The East South Central region had the "average" cost/GGE $\mathrm{H}_{2}$ delivered thus estimated. We then assumed that (1) the East South Central region's pipeline delivery costs are the same as 
the national average estimated above and shown in Table 4.4 and (2) the delivery costs for all of the other regions are variants of that cost, based on each region's cost/GGE $\mathrm{H}_{2}$ delivered relative to the East South Central's cost/GGE $\mathrm{H}_{2}$ delivered. The regional pipeline delivery costs thus estimated are presented in the Appendices.

The effect of land or right-of-way costs are not included in our estimates of pipeline delivery costs. Land costs vary significantly among the regions of the United States, and, in an absolute sense, such costs tend to be non-trivial. However, we examined land costs as a percentage of current pipeline costs and found that on a percentage basis, they are a minor part of pipeline cost (Oil and Gas Journal 1999, 2001, and 2003). Table 4.5 summarizes our findings. Costs for six years are shown: 1998-2003. On a percentage basis, land costs vary from $2.9 \%$ to $9.5 \%$ of total pipeline costs during this period. The average is $5.8 \%$. On a per-mile basis, the Oil and Gas Journal (September 8, 2003) reports that for 2003, land cost is $\$ 58,619 /$ mile compared to total project cost of $\$ 1,286,000 /$ mile, or less than $5 \%$ of total pipeline costs (Oil and Gas Journal 2003).

Further, because the transition from petroleum/natural-gas-based fuels is anticipated to occur as a result of the reduced availability and escalated cost of these fuels, our scenario also anticipates the reduced use of existing oil and gas pipelines. Hence, we assume that the hydrogen energy supply industry will strive to use existing rights-of-way that have become available as a result of the emergence of spare pipeline capacity as the supply of natural and petroleum-based fuels diminishes.

On the basis of these premises, this study assumes that right-of-way costs will continue to be a minor component - less than 5\% percent of total — of the cost of building pipelines to transport $\mathrm{H}_{2}$. Therefore, we left right-of-way costs out of our analysis. We recognize, however, that the magnitude of the $\mathrm{H}_{2}$ infrastructure that would need to be developed to support a sizeable FCV market penetration suggests that further analysis of total right-of way costs is warranted.

TABLE 4.5 Summary of Oil and Gas Journal Pipeline Right-of-Way Cost Investigations

\begin{tabular}{crccl}
\hline Period & Total Cost (\$) & $\begin{array}{c}\text { Rights of Way } \\
\text { and Damages (\$) }\end{array}$ & $\begin{array}{c}\text { Land Cost/ } \\
\text { Total Cost (\%) }\end{array}$ & \multicolumn{1}{c}{ Comments } \\
\hline 2003 & $1,166,584,784$ & $53,154,705$ & $4.6 \%$ & $\begin{array}{l}\text { OGJ, Sept. 8, 2003, p. 72. } \\
\text { July 1, 02 to June 30, 03 period (typical) }\end{array}$ \\
2002 & $2,023,766,121$ & $77,551,159$ & $3.8 \%$ & OGJ, Sept. 8, 2003, p. 72. \\
2001 & $1,468,338,874$ & $134,551,570$ & $9.2 \%$ & OGJ, Sept. 3, 2001, p. 74. \\
2000 & $2,246,011,324$ & $213,871,544$ & $9.5 \%$ & OGJ, Sept. 3, 2001, p. 74. \\
1999 & $979,596,710$ & $76,662,856$ & $7.8 \%$ & OGJ, Aug. 23, 1999, p. 57. \\
1998 & $3,438,682,971$ & $99,468,844$ & $2.9 \%$ & OGJ, Aug. 23, 1999, p. 57; includes Canada. \\
Average & & & $\mathbf{5 . 8 \%}$ & \\
\hline
\end{tabular}




\subsubsection{Regional Delivery Costs: Other}

For $\mathrm{H}_{2}$ delivery by truck, we used a process similar to that described above for pipelines to develop regional costs. As with pipelines, we estimated that average truck delivery distances would be shorter in regions with greater urban density. The regional truck delivery costs thus estimated are presented in the Appendices.

None of the above discussion applies to the delivery of $\mathrm{H}_{2}$ produced by centralized electrolysis. Because we did not develop regional costs for producing $\mathrm{H}_{2}$ by this method (as discussed in Section 4.2.1), we did not develop the associated regional delivery costs. Also, we used delivery costs for tube trailers (starting with SFA's estimates), although we meant to assume use of liquefied $\mathrm{H}_{2}$ tankers, particularly in the early years. However, we have not changed these costs and present them in Table A-4.

\subsection{DISTRIBUTED PRODUCTION}

\subsubsection{Station Volumes}

The volume of $\mathrm{H}_{2}$ produced at a station is one of the major variables in the cost of distributed production, particularly from natural gas. In Section 3.3, we estimated the total volume of $\mathrm{H}_{2}$ that would be produced at stations in each region by year for the GYOW scenario. For our cost analysis, we need to estimate how many stations will be built to dispense that volume. The estimation method is explained below.

\subsubsection{Year 2020}

For distributed production at non-metropolitan area interstate stations in 2020 (which is the only distributed production we assume in that year), we first reviewed data available on several state web sites that indicated the distance between interchanges along interstates (largely, but not all, rural) in those states (Pennsylvania Turnpike 2003, Kansas Turnpike Authority 2003, and Ohio Turnpike 2003). We found the average or typical distance to be 30 miles. We assume that there is at least one fuel-dispensing station at each of these interchanges and that it serves traffic going in both directions along the interstate. From U.S. EPA VMT data by road type and supporting documentation, we were able to estimate the number of interstate miles in nonmetropolitan counties (by county). We estimate that in 2002, there were approximately 21,000 miles of interstate roads in the United States in non-metropolitan counties. We developed these estimates by region. If we assume that there is a station on average every 30 miles, then there should be approximately 700 stations on non-metropolitan area interstates. We also developed these estimates by region.

For our $\mathrm{H}_{2}$ cost analysis, we assumed that one-half of these stations would provide $\mathrm{H}_{2}$ in 2020. Given these station totals (by region) and our estimates of the total volume of $\mathrm{H}_{2}$ produced at stations in each region (see Table 3.9), we can then estimate average station volumes by 
region. The resulting range of station volumes across regions for the year 2020 is shown in Table 4.6.

\subsubsection{Years 2030-2050}

As indicated in Section 2, in the GYOW scenario, we assume that by 2040 FCVs will be able to, on average, complete all of the non-metropolitan area travel of today's vehicles. In other words, they are assumed to be able to travel throughout the United States without refueling limitations. For that to happen, we assume that $\mathrm{H}_{2}$ eventually will be available at all service stations in non-metropolitan areas. We used the current number of gasoline stations in nonmetropolitan areas as a first-cut estimate of the number needed to dispense $\mathrm{H}_{2}$ in the future. There are at least two sets of estimates of the number of existing stations: we used the U.S. Economic Census data because only those data identify stations by county (U.S. Census Bureau 2000). For 2030, when FCV travel in non-metropolitan areas is still expanding, we assume that only $60 \%$ of those stations will provide $\mathrm{H}_{2}$. The total number of $\mathrm{H}_{2}$ stations in the United States in non-metropolitan areas thus estimated is presented in Table 4.6.

Not all of these stations will produce $\mathrm{H}_{2}$ at the station. In Section 3.3, we assumed that $75 \%$ of the $\mathrm{H}_{2}$ stations in non-metropolitan areas would provide $\mathrm{H}_{2}$ via distributed production. Given these station totals (by region) and our estimates of the total volume of $\mathrm{H}_{2}$ produced at stations in each region (see Table 3.9), we can then estimate average station volumes by region. The resulting range of station volumes across regions for the years 2030-2050 is shown in Table 4.6. We assume the volume dispensed at interstate stations is included in these estimates.

Table 4.6 Number of Non-Metropolitan Area Stations Producing $\mathrm{H}_{2}$ at the Station and Volume/Month in the GYOW Scenario

\begin{tabular}{ccccc}
\hline Year & $\begin{array}{c}\text { Total Number of } \\
\mathbf{H}_{2} \text { Stations in } \\
\text { Non-Metropolitan } \\
\text { Areas }\end{array}$ & $\begin{array}{c}\text { Number of } \mathbf{H}_{2} \\
\text { Stations Producing } \\
\mathbf{H}_{\mathbf{2}} \text { in Non- } \\
\text { Metropolitan Areas }\end{array}$ & $\begin{array}{c}\text { Volume Dispensed per } \\
\text { Month (GGE): } \\
\text { U.S. Average }\end{array}$ & $\begin{array}{c}\text { Volume Dispensed per } \\
\text { Month (GGE): } \\
\text { Regional Range }\end{array}$ \\
\hline 2010 & $\mathrm{NA}$ & $\mathrm{NA}$ & $\mathrm{NA}$ & $\mathrm{NA}$ \\
2020 & 325 & 325 & 12,454 & $0-1,721$ \\
2030 & 23,952 & 17,974 & 8,065 & $7,031-10,283$ \\
2040 & 39,942 & 29,957 & 17,910 & $15,613-22,836$ \\
2050 & 39,942 & 29,957 & 22,161 & $19,319-28,255$ \\
\hline
\end{tabular}

$\mathrm{NA}=$ not applicable 


\subsubsection{Station Cost Analysis}

The analysis of the cost of distributed production of $\mathrm{H}_{2}$ is also based on one of the SFA models, with some changes and simplifications. The major differences from the centralized production models are summarized below:

- Energy costs are based on EIA commercial sector projections rather than industrial (EIA 2003a).

- Distribution costs are not separated because the production occurs at the dispensing point.

- Reformer efficiency was increased from $70 \%$ to $85 \%$ during the $2020-2050$ time period. However, we have made no other technology improvement assumptions or financial assumptions that would significantly reduce cost during the analysis period.

- This equipment is expected to have a shorter lifetime and, hence, higher amortization factors than the central equipment.

The regional estimates of station volume discussed above were converted to number of refills per day (at approximately $4 \mathrm{GGE} /$ refill). These estimates, in turn, were used to estimate reforming capacities and cost for $\mathrm{H}_{2}$ produced at distributed stations employing natural gas reforming technology. The specific regional estimates can be found in the Appendix (Table A.5).

These same regional production volumes and refill requirements were used for the capacities of stations using electrolysis to produce $\mathrm{H}_{2}$. Because of time constraints, we only estimated the costs for five regions in detail (see Table A.6). Subsequently, by examining regional differences in commercial electricity costs, we estimated the total cost of using electrolysis for the remaining four regions (see Table A.7).

Analysis of the distributed electrolysis results indicates that the per-GGE costs for electrolysis are relatively insensitive to station size. Indeed, a 10\% increase in station size yields a cost reduction of only about a $1 \%$ electrolyzer per kilowatt. A $100 \%$ increase in size yields a cost reduction of only 7\% per kilowatt. In contrast, modeling of the production of $\mathrm{H}_{2}$ from natural gas showed that an increase in station size of $100 \%$ yields about a $16 \%$ reduction in unit costs. Note that we allowed electrolyzer efficiency to increase to $85 \%$ by 2040 , on the basis of the DTI optimistic projection of up to $89 \%$ (Myers et al. 2003).

The biggest factor driving the production cost for electrolysis is the $\$ 2,000$ per kilowatt baseline cost factor. (At least one other report has lower estimates. See a comparison of SFA's costs with those of DTI's in Appendix Table B.1.) Nearly 60\% of the per-GGE cost is due to the electrolyzer capital cost, with commercial electricity costs in the $6-7 \phi / \mathrm{kWh}$ range. If electricity cost were in the $2-3 \phi / \mathrm{kWh}$ range, then about $80 \%$ of the per-GGE cost would be due to capital cost. 


\subsection{OBSERVATIONS ON $\mathrm{H}_{2}$ PRODUCTION COST ESTIMATES}

The commercialization of $\mathrm{H}_{2}$ production and distribution systems is highly capital intensive. Therefore, there is limited sensitivity to process efficiency and input energy (feedstock) cost. For example, a doubling of the natural gas feedstock costs that we used would result in a $20-30 \%$ increase in delivered $\mathrm{H}_{2}$ costs over time in the Mid-Atlantic region.

We have estimated substantial reductions over time in virtually all of our centralized production pathways. We have also estimated reductions in the distributed production of $\mathrm{H}_{2}$, but there may be greater opportunities for cost reduction in distributed production by using electrolysis than we have estimated. As indicated above, comparisons of SFA's costs with those of DTI's are provided in Appendix Table B.1.

Finally, our cost estimates are generally higher than the cost goals of the U.S. DOE $\mathrm{H}_{2}$ program.

\subsection{FINAL DELIVERED $\mathrm{H}_{2}$ COST ESTIMATES FOR THE GYOW SCENARIO}

As indicated in Section 4.1, the cost estimates discussed above are tied to specific fuel volumes. Using these volume specific cost estimates, the Regional $\mathrm{H}_{2}$ Model generates final cost estimates for any scenario of $\mathrm{H}_{2}$ demand. Table 4.7 presents the final year-by-year, technologyby-technology, and region-by-region $\mathrm{H}_{2}$ cost estimates of the GYOW scenario. The national estimates are summarized in Table 4.8 and Figure 4.1. Again, no taxes are included in the cost estimates.

As the tables and figure illustrate, the cost of producing, delivering, and dispensing $\mathrm{H}_{2}$ declines over time for virtually all of the technologies. However, the increasing use of relatively expensive distributed $\mathrm{H}_{2}$ production, particularly from electrolysis, to meet the needs of travel in non-metropolitan areas leads to an essentially stable average cost of $\mathrm{H}_{2}$ of around $\$ 3.70 / \mathrm{GGE}$ (see Figure 4.2) from 2020 to 2050. This figure also illustrates the very large difference that exists between the cost of $\mathrm{H}_{2}$ in metropolitan and non-metropolitan areas: nearly $\$ 5 / \mathrm{GGE}$ by 2050 (national average). Table 4.9 presents the metropolitan and non-metropolitan area costs by region.

Figure 4.3 illustrates the range in average costs across the country. By 2050, regional $\mathrm{H}_{2}$ costs vary from $\$ 2.97 / \mathrm{GGE}$ (contiguous Pacific) to $\$ 6.65 / \mathrm{GGE}$ (Alaska). Alaska is unique. The next highest $\mathrm{H}_{2}$ costs (between $\$ 4.50$ and $\$ 4.82 / \mathrm{GGE}$ ) are in the West North Central, Mountain, and Hawaii regions. In essence, excluding Alaska, we estimate a range of $\mathrm{H}_{2}$ cost differentials across regions of nearly $\$ 2 / \mathrm{GGE}$ by 2050 . (The variation, excluding Alaska, is approximately $\$ 1 /$ GGE in $2020, \$ 1.20 /$ GGE in 2030, and $\$ 2 /$ GGE in 2040.) This result - the potential for great regional variation in $\mathrm{H}_{2}$ costs - is one of the main points that we wanted to illustrate with this analysis. 


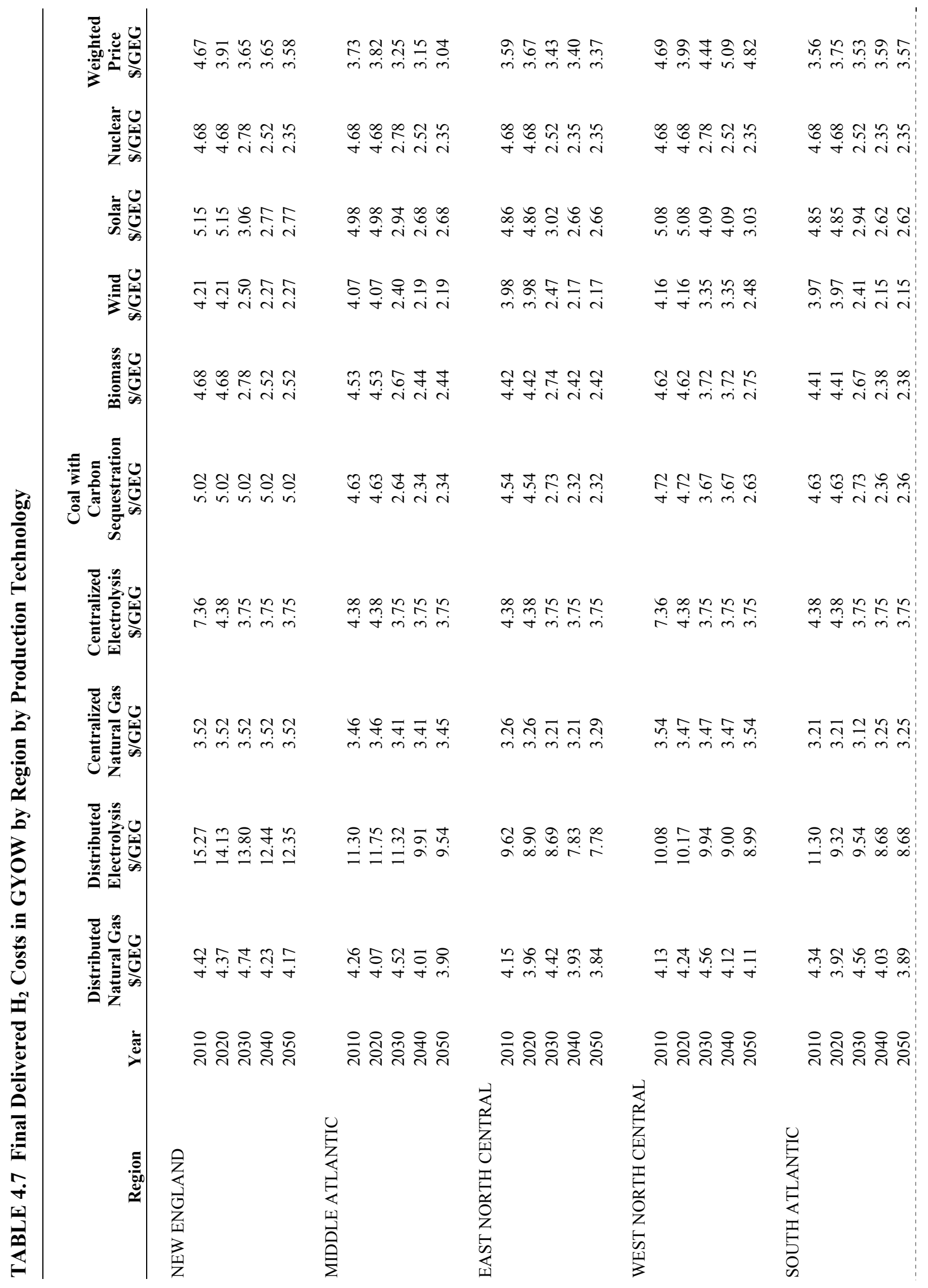




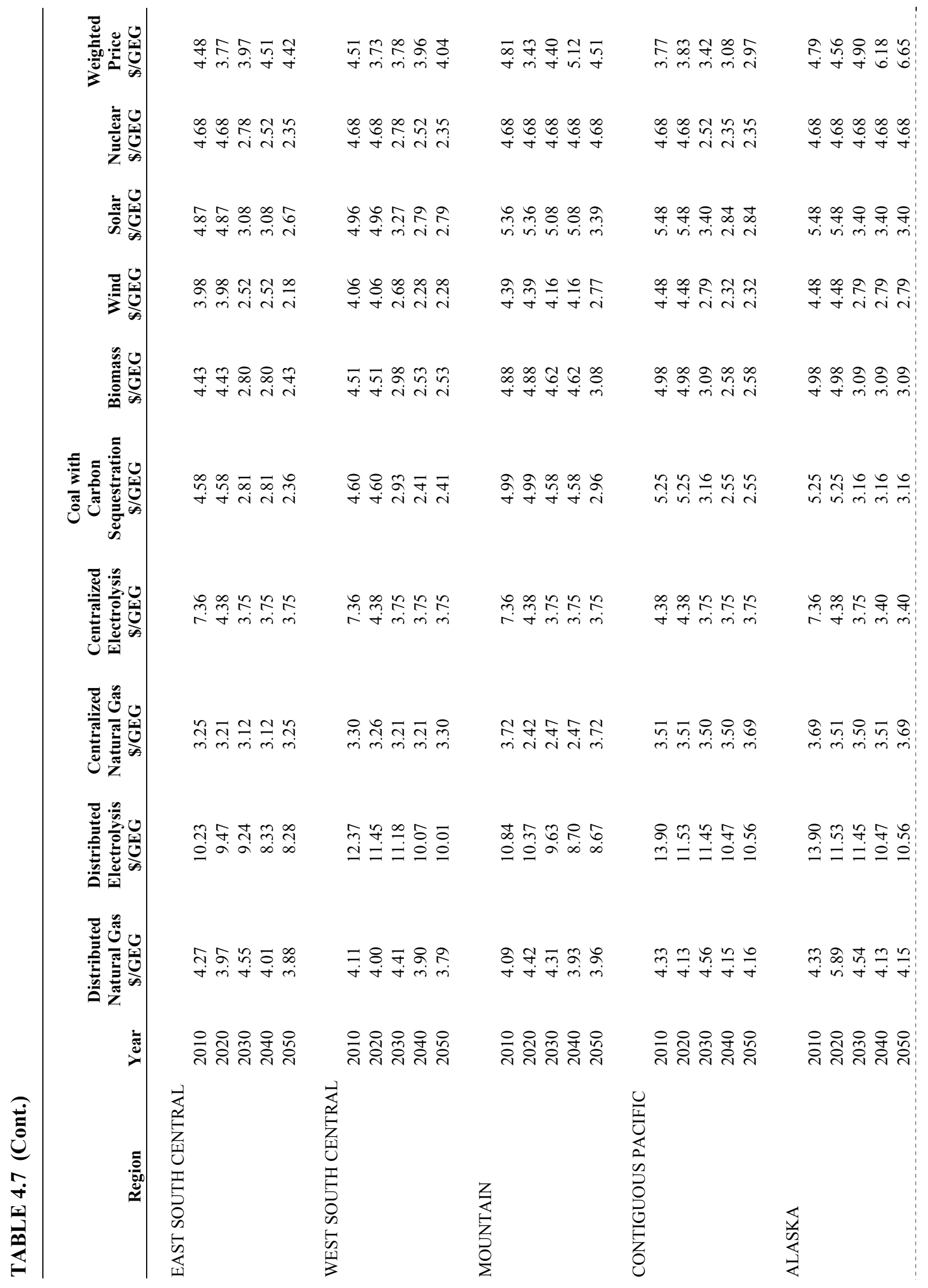




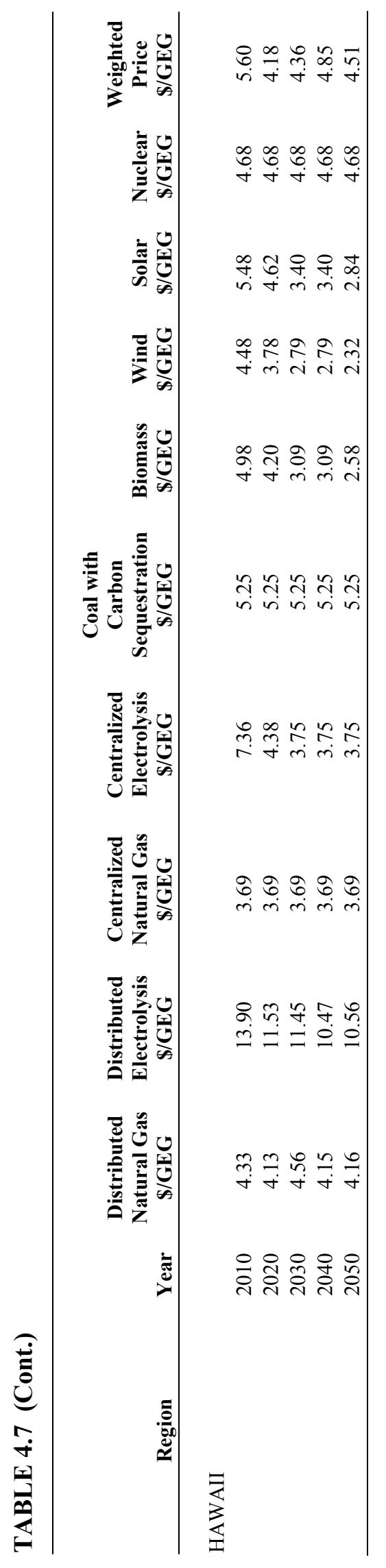


TABLE 4.8 Final Delivered $\mathrm{H}_{2}$ Costs in GYOW: U.S. Summary by $\mathrm{H}_{2}$ Production Technology

\begin{tabular}{|c|c|c|c|c|c|c|c|c|c|c|c|}
\hline \multirow[b]{2}{*}{ Year } & \multirow[b]{2}{*}{$\begin{array}{c}\text { GGE } \\
\text { (billions) }\end{array}$} & \multicolumn{10}{|c|}{$\mathrm{H}_{2}$ Cost (\$/GGE) } \\
\hline & & $\begin{array}{c}\text { Distributed } \\
\text { Natural Gas }\end{array}$ & $\begin{array}{l}\text { Distributed } \\
\text { Electrolysis }\end{array}$ & $\begin{array}{c}\text { Centralized } \\
\text { Natural Gas }\end{array}$ & $\begin{array}{l}\text { Centralized } \\
\text { Electrolysis }\end{array}$ & $\begin{array}{c}\text { Coal with } \\
\text { Sequestration }\end{array}$ & Biomass & Wind & Solar & Nuclear & Total \\
\hline 2010 & 0.001 & NA & NA & 3.38 & 5.53 & NA & 4.98 & 4.48 & 5.48 & NA & 4.03 \\
\hline 2020 & 0.93 & 4.09 & 10.17 & 3.28 & 4.38 & NA & 4.20 & 3.78 & 4.62 & NA & 3.76 \\
\hline 2030 & 16.5 & 4.48 & 9.99 & 3.25 & 3.75 & 2.95 & 2.87 & 2.97 & 3.45 & 2.63 & 3.67 \\
\hline 2040 & 36.7 & 3.98 & 9.02 & 3.26 & 3.75 & 2.62 & 2.57 & 2.67 & 3.07 & 2.42 & 3.77 \\
\hline 2050 & 45.4 & NA & 8.96 & NA & 3.75 & 2.43 & 2.49 & 2.39 & 2.86 & 2.35 & 3.68 \\
\hline
\end{tabular}

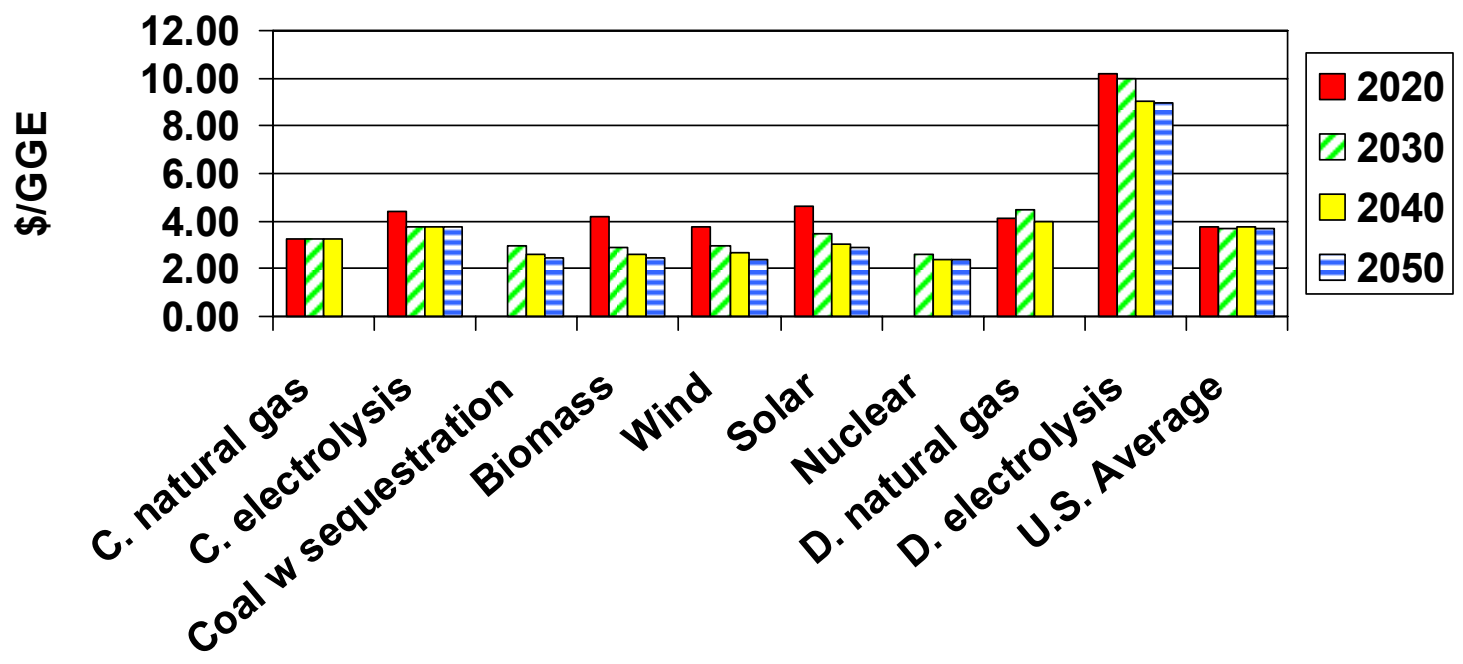

FIGURE 4.1 Final Delivered $\mathrm{H}_{2}$ Cost in GYOW: U.S. Summary by $\mathrm{H}_{2}$ Production Technology

\subsection{SENSITIVITY ANALYSIS}

There are many assumptions underlying our estimates. In Table 4.10, we show the impacts of varying just three of those assumptions related to distributed production. If we change our assumption that natural gas use for $\mathrm{H}_{2}$ production will be phased out by 2050 to one in which it continues to be used for distributed production and in substantial amounts $(65 \%$ of all distributed production), the average cost of $\mathrm{H}_{2}$ in the United States by 2050 would fall from $\$ 3.68 /$ GGE to $\$ 3.10 /$ GGE by 2050 . If, instead, our estimates of the cost of distributed production from electrolysis were modified to be more similar to those presented in Appendix B (in effect cutting our estimates almost in one-half), then the average cost of $\mathrm{H}_{2}$ in the United States by 2050 would fall even further, to $\$ 2.89 /$ GGE. Alternatively, if we assume that all nonmetropolitan travel by FCVs is served by distributed production (instead of $75 \%$ ), then the average cost of $\mathrm{H}_{2}$ in the United States by 2050 would increase to $\$ 4.10 / \mathrm{GGE}$. In sum, varying just these assumptions results in a swing of over $\$ 1 / \mathrm{GGE}$ of $\mathrm{H}_{2}$ (national average). 


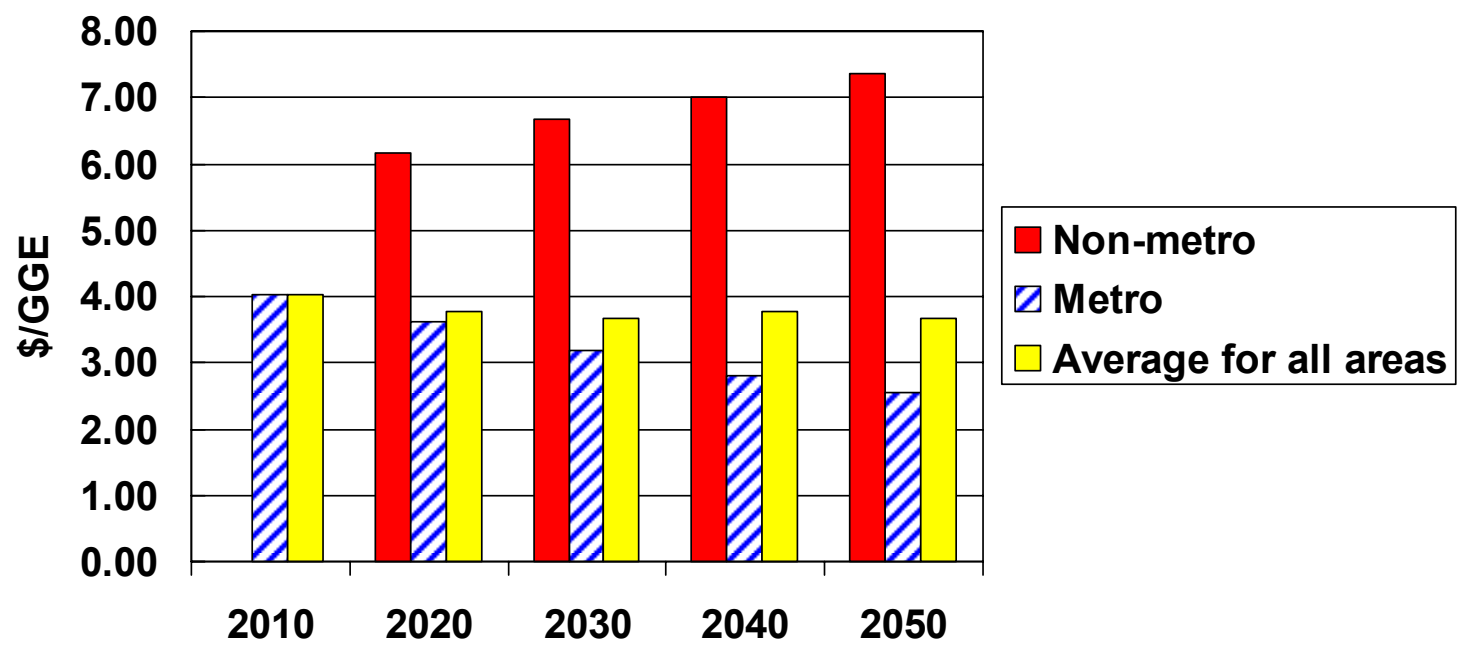

Figure 4.2 Final Delivered $\mathrm{H}_{2}$ Cost in GYOW: U.S. Summary by Metropolitan versus Non-Metropolitan Areas

Finally, in Table 4.11, we present the impacts of varying these same three assumptions on $\mathrm{H}_{2}$ costs in metropolitan and non-metropolitan areas. Where there is a difference of nearly \$5/GGE in the cost of $\mathrm{H}_{2}$ in metropolitan and non-metropolitan areas in the GYOW scenario by 2050 , that cost difference is dramatically lowered to less than $\$ 2.50 /$ GGE if natural gas continues to be used for distributed production and approximately $\$ 1.50 / \mathrm{GGE}$ if the cost of distributed production from electrolysis is reduced by $50 \%$. The difference is increased if all nonmetropolitan travel by FCVs is served by distributed production. 


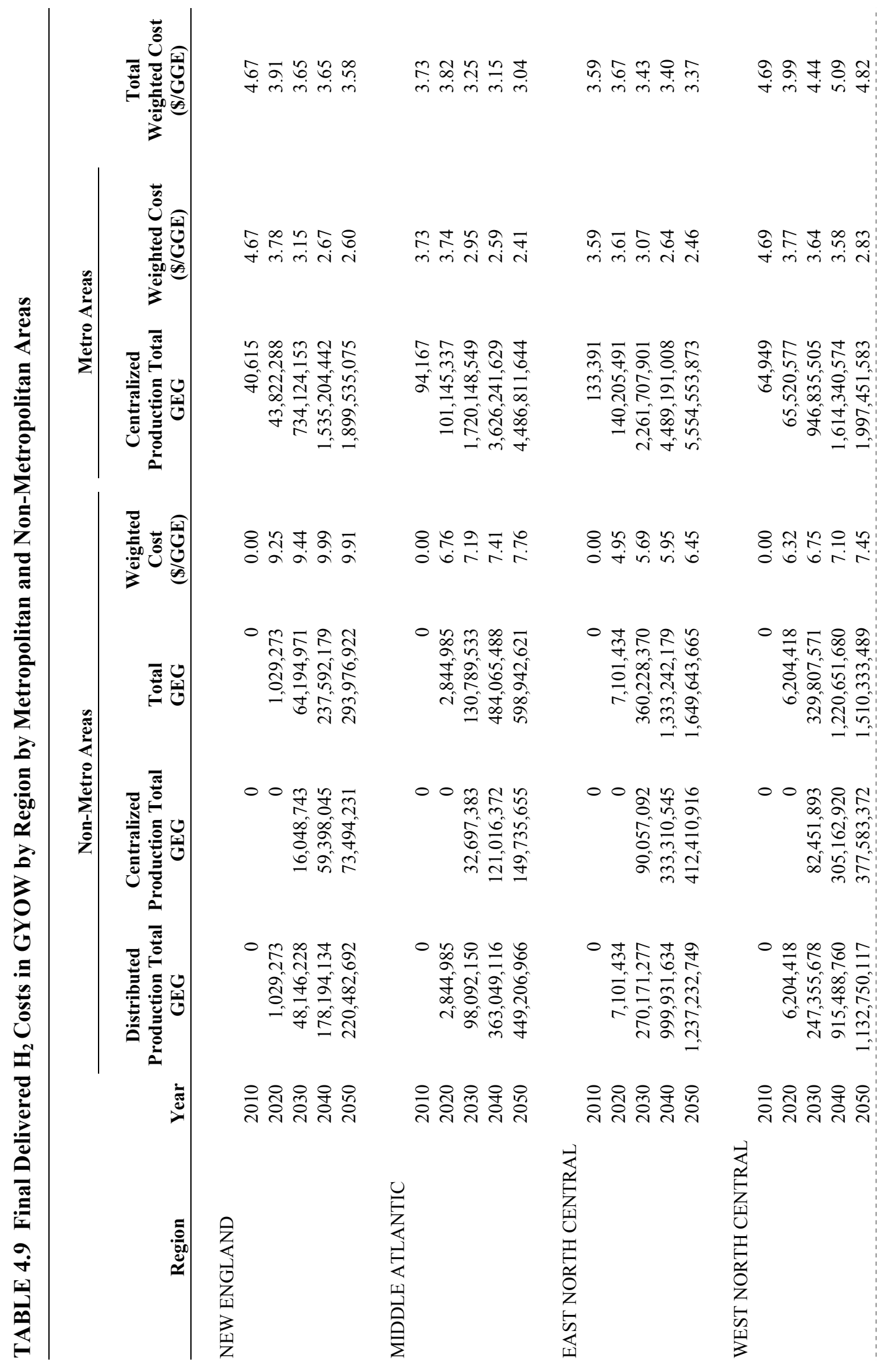




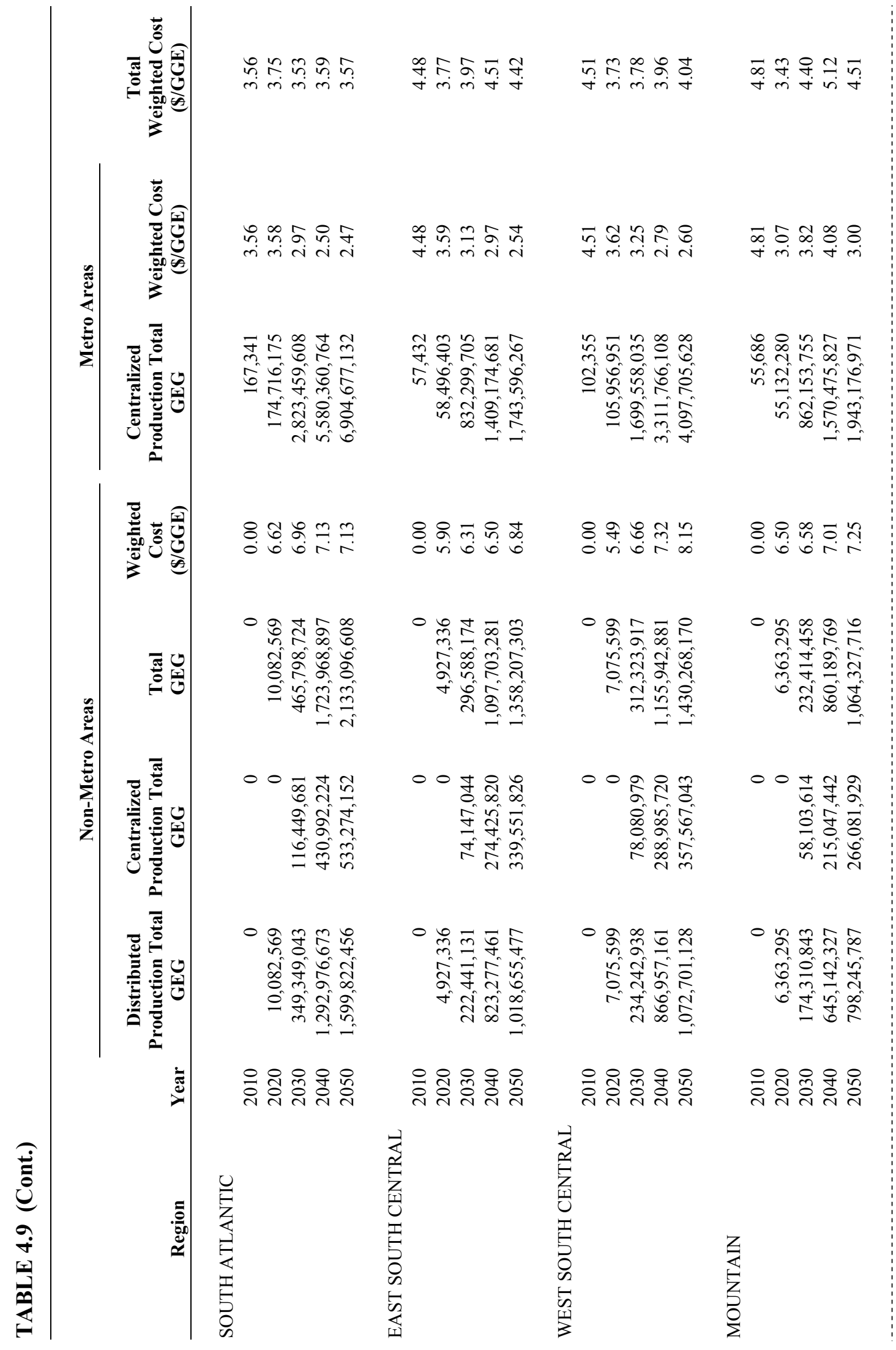




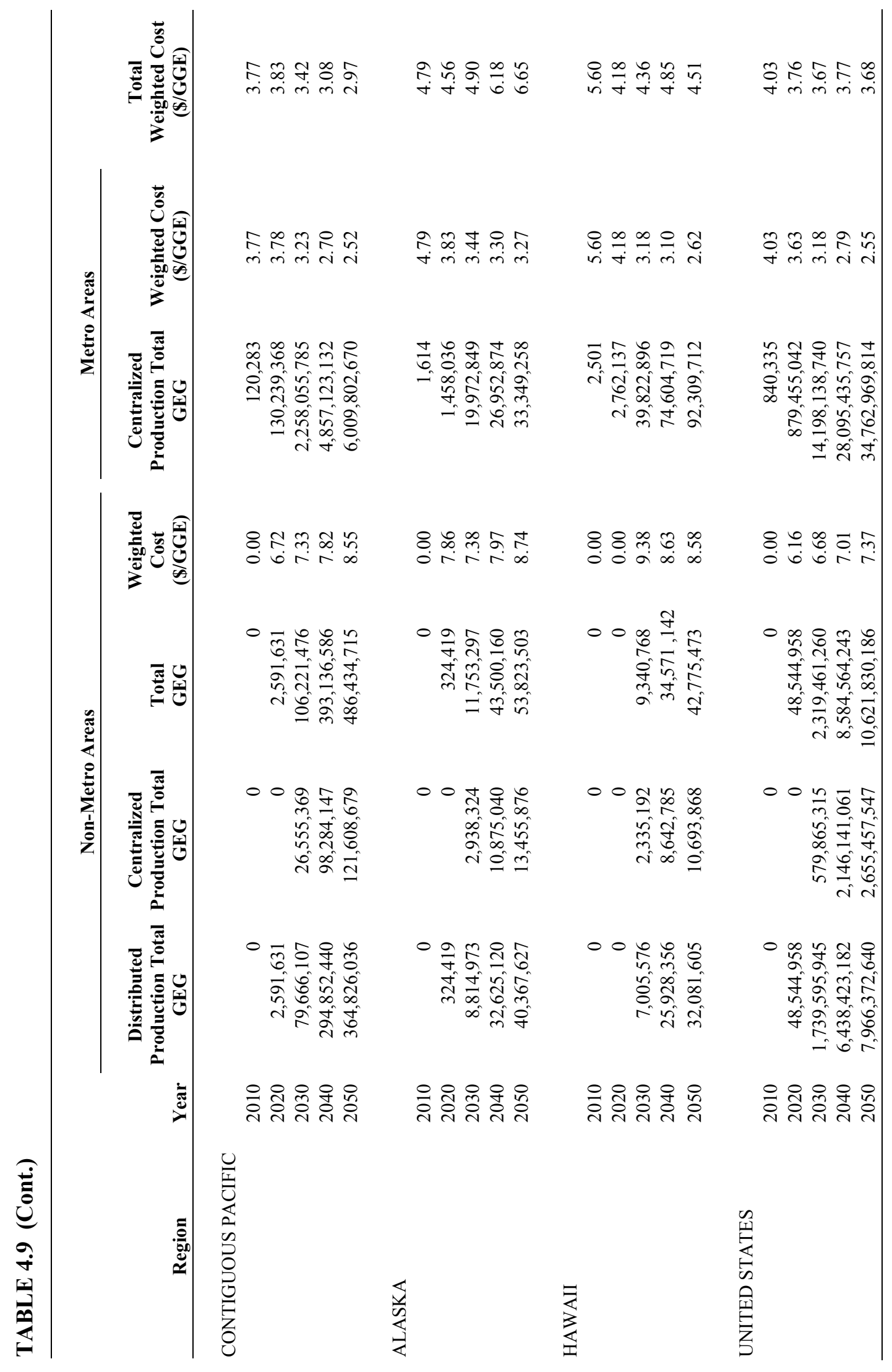




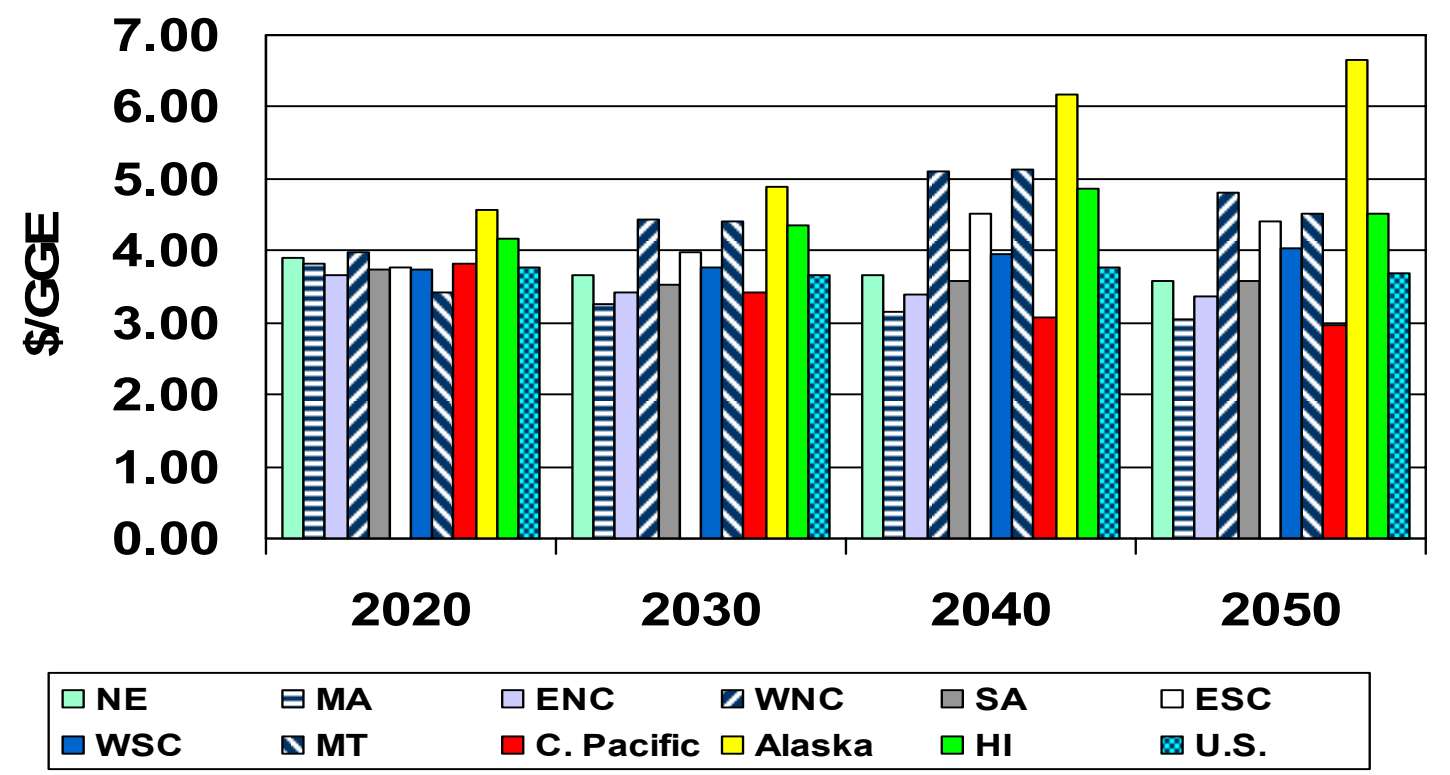

Figure 4.3 Regional $\mathrm{H}_{2}$ Costs in GYOW

Table 4.10 Sensitivity Cases Altering Distributed Production Assumptions of GYOW: U.S. Average $\mathrm{H}_{2}$ Cost

\begin{tabular}{llllll}
\hline & \multicolumn{5}{c}{ H$_{2}$ Cost (\$/GGE), by Year } \\
\cline { 2 - 6 } \multicolumn{1}{c}{ Scenario } & $\mathbf{2 0 1 0}$ & $\mathbf{2 0 2 0}$ & $\mathbf{2 0 3 0}$ & $\mathbf{2 0 4 0}$ & $\mathbf{2 0 5 0}$ \\
\cline { 2 - 6 } & 4.03 & 3.76 & 3.67 & 3.77 & 3.68 \\
GYOW & 4.03 & 3.76 & 3.52 & 3.31 & 3.10 \\
$\begin{array}{l}\text { GYOW with Continued Use of } \\
\text { Natural Gas for Distributed }\end{array}$ & & & & & \\
$\begin{array}{l}\text { Production to 2050 (65\% of all } \\
\text { distributed production in 2050) }\end{array}$ & & & & & \\
$\begin{array}{l}\text { GYOW with Cost of Distributed } \\
\text { Production from Electrolysis at } \\
\text { 50\% of Original GYOW Cost }\end{array}$ & 4.03 & 3.67 & 3.35 & 3.09 & \\
$\begin{array}{l}\text { GYOW with 100\% of FCV Travel } \\
\text { in Non-Metropolitan Areas }\end{array}$ & 4.03 & 3.76 & 3.83 & 4.17 & \\
Served by Distributed Production & & & & & \\
\hline
\end{tabular}


Table 4.11 Sensitivity Cases Altering Distributed Production Assumptions of GYOW: Average U.S. Metropolitan (M) and Non-Metropolitan (NM) $\mathrm{H}_{2}$ Cost

\begin{tabular}{|c|c|c|c|c|c|c|c|c|c|c|}
\hline \multirow[b]{3}{*}{ Scenario } & \multicolumn{10}{|c|}{$\mathrm{H}_{2}$ Cost (\$/GGE), by Year } \\
\hline & \multicolumn{2}{|c|}{2010} & \multicolumn{2}{|c|}{2020} & \multicolumn{2}{|c|}{2030} & \multicolumn{2}{|c|}{2040} & \multicolumn{2}{|c|}{2050} \\
\hline & $\mathbf{M}$ & NM & $\mathbf{M}$ & NM & $\mathbf{M}$ & NM & $\mathbf{M}$ & NM & $\mathbf{M}$ & NM \\
\hline GYOW & 4.03 & - & 3.63 & 6.16 & 3.18 & 6.68 & 2.79 & 7.01 & 2.55 & 7.37 \\
\hline $\begin{array}{l}\text { GYOW with Continued } \\
\text { Use of Natural Gas for } \\
\text { Distributed Production to } \\
2050\end{array}$ & 4.03 & - & 3.63 & 6.16 & 3.18 & 5.60 & 2.79 & 5.04 & 2.55 & 4.90 \\
\hline $\begin{array}{l}\text { GYOW with Cost of } \\
\text { Distributed Production } \\
\text { from Electrolysis at } 50 \% \text { of } \\
\text { Original GYOW Cost }\end{array}$ & 4.03 & - & 3.63 & 4.43 & 3.18 & 4.41 & 2.79 & 4.07 & 2.55 & 4.01 \\
\hline $\begin{array}{l}\text { GYOW with } 100 \% \text { of FCV } \\
\text { Travel in Non- } \\
\text { Metropolitan Areas Served } \\
\text { by Distributed Production }\end{array}$ & 4.03 & - & 3.63 & 6.16 & 3.18 & 7.83 & 2.88 & 8.37 & 2.61 & 8.96 \\
\hline
\end{tabular}




\section{ALTERNATIVE SCENARIOS IN REGIONAL $\mathrm{H}_{2}$ MODEL}

As indicated previously, the Regional $\mathrm{H}_{2}$ Model used to develop regional $\mathrm{H}_{2}$ production and cost estimates for the GYOW scenario can be used to develop such estimates for alternative scenarios. The current version of the model is called "Regional $\mathrm{H}_{2}$ Model 1.0." It is an Excel spreadsheet model. In its current form, it is not "user-friendly," but it is somewhat flexible. The alternative scenarios that can be evaluated most easily include those that assume:

1. Alternative national total $\mathrm{H}_{2}$ demand,

2. Alternative percentages of non-metropolitan travel served by distributed $\mathrm{H}_{2}$ production, and

3. Alternative estimates of the share of distributed $\mathrm{H}_{2}$ production that will be provided by steam reforming of natural gas versus electrolysis.

In Section 4.5, we saw the results of altering assumptions 2 and 3.

Alternative evaluations of regional resource fuels, alternative assumptions guiding the use of these fuels over time and at various demand levels, and alternative regional $\mathrm{H}_{2}$ fuel costs by type of resource fuel can also be input to the model, although not as easily as the three factors listed above. Considerable work remains to enhance the flexibility of this model to evaluate a wide variety of alternative scenarios (e.g., including those that allow FCVs to penetrate the regions assuming different start dates).

Appendix $\mathrm{C}$ contains a summary of the key assumptions underlying the existing version of the model. 


\section{ISSUES REQUIRING FURTHER ANALYSIS}

Obviously, there are many issues involved in adequately estimating what resources might be used to produce $\mathrm{H}_{2}$ and what $\mathrm{H}_{2}$ costs will be regionally and nationally. The list below reflects some of the issues that we faced and others that we believe need to addressed in order to develop reliable estimates of regional $\mathrm{H}_{2}$ demand, production, and cost. The list is not meant to be exhaustive.

\subsection{ISSUES RELATED TO ESTIMATES OF $\mathrm{H}_{2}$ PRODUCTION FROM VARIOUS RESOURCE FUELS}

\subsubsection{Resource Potential of $\mathrm{H}_{2}$ Resource Fuels}

Are the assessments of the resource potential of each resource fuel accurate or can better data be used? The data used to assess coal and natural gas resources in this report are very good. The methodology used to weight natural gas reserves and the existing natural gas distribution system into an overall resource potential for $\mathrm{H}_{2}$ production from natural gas should be reviewed for potential revision. The biomass volumes per state were taken from a well-developed reference; however, they may require updating. The wind and solar resource assessments can be updated with more in-depth analysis and better data: we used maps illustrating their potential, not the data supporting the maps. The potential for existing power plants to provide electricity for $\mathrm{H}_{2}$ production and the potential for $\mathrm{H}_{2}$ generation via thermochemical water splitting by using advanced, high-temperature nuclear reactors is simply based on assumption and requires further evaluation.

\subsubsection{Development of Regional $\mathrm{H}_{2}$ Supply Curves}

Can we bring delivered $\mathrm{H}_{2}$ cost estimates for the various resource fuel pathways to bear on evaluating the relative attractiveness of each $\mathrm{H}_{2}$ pathway in each region? Use of regional $\mathrm{H}_{2}$ supply curves (volume of $\mathrm{H}_{2}$ available at specific costs - from different pathways) would be a preferable way to evaluate the degree to which alternative resource fuels are used to produce $\mathrm{H}_{2}$. DTI used such curves when evaluating the potential for renewable resources to supply $\mathrm{H}_{2}$ (Myers et al. 2003). DTI's analysis was conducted at the state level and considered competing demand for the renewable resources. But it did not consider fossil or nuclear resource fuels. 


\subsubsection{Interregional Production and Transport of $\mathrm{H}_{2}$}

We assume that each Census region's demand is met by production from resource fuels in that Census region only. We expect that the market will evolve differently and that, for many regions, some regional $\mathrm{H}_{2}$ demand will be met by $\mathrm{H}_{2}$ produced externally to those regions. This latter assumption needs to be evaluated. For example, coal is currently shipped from one Census region to another for use in power plants. (A review of National Mining Association data indicates that over 20 states consume much more coal per year [10 million tons] than they produce (NMA 2004a,b). It could be so shipped for $\mathrm{H}_{2}$ production, and a region's $\mathrm{H}_{2}$ demand would thus be met partially by resources from outside the region. DTI's methodology appears to have resulted in $\mathrm{H}_{2}$ demand in one region being met by $\mathrm{H}_{2}$ produced from another region (Myers et al. 2003).

\subsection{ISSUES RELATED TO $\mathrm{H}_{2}$ DEMAND, ESPECIALLY IN NON-METROPOLITAN AREAS, AND THE REFUELING FACILITIES THAT NEED TO BE ESTABLISHED TO SERVE THAT DEMAND}

\subsubsection{Rural Travel Requirements}

In general, ensuring that $\mathrm{H}_{2}$ is available for FCV travel in rural or non-metropolitan areas is a major concern. To analyze and address that concern, we need to know what the level of $\mathrm{H}_{2}$ demand in non-metropolitan areas will be. One issue to be considered is whether we should expect FCVs to eventually fulfill the same rural travel requirements as the average vehicle today. In our analysis, we assumed that FCVs gradually will be used to meet the same rural travel requirements as the average vehicle today. We believe that assumption should be examined for any market penetration level that is less than $100 \%$.

\subsubsection{Nature of Rural Interstate Travel}

What is the nature of rural interstate travel? An assumption of our analysis is that the first travel by FCVs in non-metropolitan areas will be on interstates between metropolitan areas. But to determine how much $\mathrm{H}_{2}$ will be required by FCVs for that travel, we need to better understand the purpose of rural interstate travel in general. For example, how much rural interstate travel is (1) business-related by urban residents, (2) by residents of rural areas traveling from one rural location to another, and (3) "other" (such as vacation and visiting friends, etc.)?

\subsubsection{Potential Changes in Rural or Non-Metropolitan Travel}

Will the magnitude of the average light vehicle's rural or non-metropolitan travel change in the future? In this analysis, we have relied on existing travel data for non-metropolitan areas to estimate potential $\mathrm{H}_{2}$ demand by FCVs in those areas. Will the United States become more urban and metropolitan? We are concerned that we may be relying too much on existing 
relationships rather than projections to estimate the amount of rural travel the average FCV will make.

\subsubsection{Magnitude of FCV Refueling Infrastructure in Non-Metropolitan Areas}

Should we expect the FCV refueling infrastructure in non-metropolitan areas to be the same as that which we have now? Will there need to be the same number of stations in essentially the same locations? Our analysis makes this assumption for non-metropolitan areas, but other options are possible.

\subsubsection{Number of Gasoline-Refueling Facilities}

How many total gasoline-refueling facilities exist, by metropolitan versus nonmetropolitan designation? How does the fact that there has been a downward trend in the total number of stations affect the analysis? The U.S. Census provides one set of total estimates of the number of gasoline stations in the United States (by county, which can be classified as metropolitan or non-metropolitan), while the National Petroleum News (NPN) survey (Davis and Diegel 2002) has a much higher total (approximately 120,000 versus 175,000) (U.S. Census Bureau 2000). The U.S. Census only includes stations for which the refueling facility at the station is the "primary business activity." This type of station may be the only type to be considered for conversion to dispensing $\mathrm{H}_{2}$, but if rural inhabitants get a good part of their gasoline from refueling facilities that are small and not the "primary business activity" of the establishment, then providing $\mathrm{H}_{2}$ to that population may be more difficult. Ideally, we would obtain data that provide the number of stations by (1) whether or not being a refueling facility is the primary business activity, (2) volume dispensed, and (3) county.

Both the U.S. Census and NPN indicate a trend toward fewer total service stations over time. We need to analyze the implications for use of $\mathrm{H}_{2}$ in rural areas. It would be interesting to know if there is any difference in the trend for metropolitan versus non-metropolitan stations.

\subsubsection{Status of Non-Metropolitan Interstate Refueling Locations}

How many non-metropolitan interstate refueling locations exist today and what is the average distance between these facilities? We estimated an average distance of 30 miles between fueling stations along largely rural interstates. We did so by looking at maps of toll roads in several states (e.g., PA, OH, IN, IL, and KS) (Pennsylvania Turnpike 2003, Kansas Turnpike Authority 2003, and Ohio Turnpike 2003). We think we should get better and/or additional data and might be able to do so from the web (perhaps with Map Quest) or Microsoft MapPoint. (We note that Melaina uses 50- and 20-mile intervals in his scenarios, but we are unsure how he selected those distances [Melaina 2003]. California is planning on 20-mile intervals [EV World 2004].) 


\subsubsection{Travel Distances to Refuel}

How far do drivers now travel in non-metropolitan versus metropolitan areas to refuel with a gasoline or diesel car/light truck (or current alternative fuels)? How much farther might they be willing to travel to refuel with an FCV? If we knew the current distances drivers travel to refueling stations and what additional distance drivers say they would be willing to travel for their fuel, we would be better able to estimate what a "reasonable" additional distance might be for an FCV. The results of one survey indicate that drivers in non-metropolitan areas travel 1.4 miles (or 70\%) farther to refuel than do drivers in metropolitan areas (ORC 2004). We need to verify these results. Also, to evaluate how much farther they would be willing to drive for fuel, we might ask in a survey about how much farther they would be willing to drive for considerably less-expensive fuel. Although $\mathrm{H}_{2}$ would not be less expensive, we would get some indication of acceptable extra travel distances.

\subsubsection{Distributed Production in Non-Metropolitan Areas in Low-H2-Demand Scenarios}

What transitional assumptions should be modified when making estimates for scenarios with lower FCV penetration? Our analysis focuses on estimating the amount of distributed production in non-metropolitan areas required for a substantial level of FCV penetration (nearly $50 \%$ of light-vehicle stock by 2050). We think the transitional assumptions that we made in GYOW should be modified when making estimates for scenarios with much lower maximum FCV penetration (i.e., 10\%). However, we are not sure what they should be.

\subsubsection{Alternative Assumptions for Provision of $\mathrm{H}_{2}$ to Non-Metropolitan Areas}

Distributed production via electrolysis is expensive, but given the assumption by the DOE Office of Hydrogen, Fuel Cells and Infrastructure Technologies (OHFCIT) that no natural gas will be used to produce $\mathrm{H}_{2}$ by 2050 and our assumption that distributed production will either use natural gas or electrolysis, electrolysis will be used to produce $100 \%$ of distributed $\mathrm{H}_{2}$ by 2050. What are the impacts of making alternative assumptions? Other options exist, such as additional use of highway distribution from centralized production plants and/or the extension of $\mathrm{H}_{2}$ pipelines that the scenario postulates will exist. In particular, the use of rights-of-way and/or existing abandoned natural gas or petroleum pipelines to move $\mathrm{H}_{2}$ may facilitate some distribution of $\mathrm{H}_{2}$ into non-metropolitan areas. An analysis of how to minimize distribution costs to these locations should be considered. Also, it might be useful to estimate what national average price of natural gas would cause a distributed gas-based system to be equal in cost to a distributed electricity-based system. This cost could then be compared with estimates of the future cost of imported natural gas. Higher levels of natural gas imports to provide the $\mathrm{H}_{2}$ for fuel cell vehicles is another option. 


\subsubsection{Reasonable Upper Bound on Distributed Production}

What is a reasonable upper bound on distributed production? The DTI analysis of the potential for renewables to provide 10 quads of $\mathrm{H}_{2}$ appears to indicate that over $70 \%$ of $\mathrm{H}_{2}$ would be "distributed" (i.e., generated at service stations), because of the cost of production from various renewable pathways (Myers et al. 2003). We estimated approximately $20 \%$ on the basis of the amount of non-metropolitan travel.

\subsection{ISSUES RELATED IN PARTICULAR TO THE EARLY YEARS OF FCV MARKET PENETRATION}

\subsubsection{Phase-In of FCVs by U.S. Census Division}

This analysis does not include any phase-in of FCVS by the U.S. Census Division. Will $F C V$ s likely be introduced in specific regions initially, or should we continue to assume universal market penetration? This analysis is largely a regional analysis, with some consideration of the transition to FCV use. We think it is likely that FCVs will penetrate the vehicle market at different rates in different regions. We suggest the following as an initial sequence among the Census regions:

1. West (contiguous Pacific) and Hawaii;

2. New England and Middle Atlantic;

3. East North Central;

4. South Atlantic;

5. West South Central;

6. East South Central; and

7. Mountain, West North Central, and Alaska.

This order is based on "brainstorming" done by the EERE/PBA Transportation Analytic Team (Singh et al. 2004).

\subsubsection{Distributed $\mathrm{H}_{2}$ Production in Metropolitan Areas}

Where will $\mathrm{H}_{2}$ provided in metropolitan areas be produced? We assumed that all $\mathrm{H}_{2}$ provided in metropolitan areas would be centrally produced. We think that in the very early years of a transition to $\mathrm{H}_{2}$, some $\mathrm{H}_{2}$ will be generated at stations in metropolitan areas. Two questions are "how much?" and "how quickly can centrally produced $\mathrm{H}_{2}$ be provided to all urban areas?" An alternative question is if sizeable distributed production facilities are established in the early years in metropolitan areas, will those facilities inhibit or preclude delivery of $\mathrm{H}_{2}$ from centralized production facilities? 


\subsection{ISSUES RELATED TO $\mathrm{H}_{2}$ PATHWAY COST ESTIMATES}

Potential refinements to the $\mathrm{H}_{2}$ cost analysis can be made. In general, once the $\mathrm{H} 2 \mathrm{~A}$ group has completed development of its analysis tool, we will review it and consider it where possible in future work (Mann 2004). Other potential refinements include the following:

Additional analysis of opportunities to reduce the costs of production equipment: These results could be reasonably expected to occur as a result of technology breakthroughs, both due to DOE-funded programs and other efforts.

Additional investigation of the cost of electricity from renewable resources: EIA does not provide cost projections for electricity from renewable resources. One reference indicates that the price of electricity from renewables needs to drop to the price of current commercial sector electricity to be viable.

Comparison of investment cost of near-term transportation options - high pressure vs. liquefied tanker - including compression and refrigeration costs at the process plants: Our estimates for the cost of moving $\mathrm{H}_{2}$ from centralized production facilities assume that in the early years, it is moved by refrigerated truck and later by pipeline. To move it by refrigerated truck requires the construction of a liquefaction unit at the $\mathrm{H}_{2}$ production facility that is not needed when the $\mathrm{H}_{2}$ begins to be moved by pipeline. We need to explore whether tube trailers might be the more cost-effective, near-term initial transport option from a total investment perspective.

Analysis of other options for distributing hydrogen in non-metropolitan locations: In particular, we might develop a scenario for extended pipeline transmission of $\mathrm{H}_{2}$ (neat or as a blend) through the existing natural gas distribution system after natural gas resource availability and pipeline shipment diminishes. This issue was also addressed under Section 6.2.8. An analysis that is more detailed than the macroscopic, regional approach applied in the work to date is needed to address this issue. The analysis could include the use of GIS technology to identify pipeline locations relative to markets and population centers.

Additional analysis of the potential right-of-way costs for $\mathrm{H}_{2}$ pipelines, as well as pipeline costs associated with reutilization of existing rights-of-way: In Section 4.2.3, we explained why we did not include pipeline right-of-way costs in our analysis: we believe they would average less than $5 \%$ of total construction costs. However, we recognize that the magnitude of the $\mathrm{H}_{2}$ infrastructure that would need to be developed to support a sizeable FCV market penetration suggests that further analysis of total right-of-way costs is warranted. We are particularly concerned about the costs of pipelines in dense urban areas. We think that analysis should also address the higher construction costs likely to occur with reutilization of existing pipeline rights-of-way.

Reexamination of the most likely $\mathrm{H}_{2}$ delivery pathways: We assumed that, by 2030, most $\mathrm{H}_{2}$ produced centrally would be delivered to stations by pipeline. We think that a mix of delivery modes should be considered and the effect on delivery costs estimated (i.e., pipeline from the central production plant to a terminal and then truck). 
Development of an estimate of the total investment required to fund the infrastructure development - both production and distribution: The DOE/NRC " 2050 " study developed such an estimate for a version of the GYOW scenario that assumed use of $\mathrm{H}_{2}$ in metropolitan areas only (see the 2050 Phase II study at http://www.ott.doe.gov/future_highway.shtml) (Patterson et al. 2003). We should develop an estimate for the scenario we have analyzed here and compare it to that study.

Assessment and update of the production capacity requirements for plants by region and by resource fuel and implications for delivery costs: We have estimated centralized production costs by assuming that the size of production facility will be the same for all resource fuels. Instead, the H2A team indicates that optimum sizes will vary by resource fuel (Mann 2004). It is possible that they will also vary by region. We need to examine, in particular, the costs of the optimum-sized plants for each resource fuel and see if they also vary by region. We should include city-gate production facilities (the size of which is "between" that of centralized and distributed production facilities) in these estimates. We also need to examine the effect of these different plant sizes on delivery costs (i.e., fewer large plants may mean longer delivery distances).

Additional analysis of the wind, solar, and nuclear-thermal technology processes and costs: Although all of the analyses and estimates include many assumptions based on professional judgments, the characterization of these costs was more limited than that for other resources. The DTI report may be of some help until the H2A analysis is complete (Myers 2003, Mann 2004).

Analysis of the potential for distributed production of $\mathrm{H}_{2}$ via ethanol reforming: Hydrogen may be produced at stations by reforming ethanol. We did not include this method of distributed production in our analysis and need to examine if it may lead to lower costs in some regions.

Calculation of costs using $\mathrm{DOE} \mathrm{H}_{2}$ program goals: Our cost estimates are generally higher than DOE's $\mathrm{H}_{2}$ program goals. We need to input the program cost goals into our model to examine the implications of these national average goals on our regional results.

\subsection{OTHER ISSUES}

Other issues that need to be addressed include:

- Effects of a regionally diverse expansion of extraction and harnessing of natural resources to produce $\mathrm{H}_{2}$ on air and water pollutants and land use: The U.S. EPA has begun to examine the implications of the $\mathrm{H}_{2}$ economy on air emissions and quality at the national and regional levels (Yeh and Loughlin 2005). 
- Availability of grid-connected FCVs: If grid-connected hybrid FCVs were available, their drivers would have different concerns about the availability of refueling facilities than those with "pure" FCVs. Should we consider these vehicle types in future analyses? Is anyone thinking of these vehicle types? 


\section{REFERENCES}

Davis, S., and S. Diegel, 2002, Transportation Energy Data Book, Edition 22, ORNL-6967, Oak Ridge National Laboratory, Oak Ridge, Tenn., Sept.

DOE: U.S. Department of Energy

DOE, 2003, Hydrogen, Fuel Cells \& Infrastructure Technologies Program: Multi-Year Research, Development and Demonstration Plan, draft, Washington, D.C., June 3 (published in February 2005; cost goals from June 3, 2003, draft).

EERE: Energy Efficiency and Renewable Energy

EERE, 2003, http://www.eere.energy.gov/windpoweringamerica/images/windmaps/wherewind 800.jpg, wind resource estimates, accessed Oct. 2003.

EIA: Energy Information Administration

EIA, 2003a, Annual Energy Outlook 2003, with Projections to 2025, DOE/EIA-0383 and Appendices, Washington, D.C., Jan.

EIA, 2003b, http://www.eia.doe.gov/emeu/states/sep_sum/html/sum_btu_1.html, Energy Consumption Estimates by Source and End-Use Sector, 2000, accessed October 2003.

EIA, 2002, U.S. Crude Oil, Natural Gas and Natural Gas Liquids Reserves, 2001 Annual Report, DOE/EIA-0216 (2001), Washington, D.C., Nov.

EIA, 2001, Annual Coal Report 2001, DOE/EIA-0584, Washington, D.C.

EIA, 2000, "Motor Gasoline Consumption, Price and Expenditure Estimates, 2000," available at http://www.eia.doe.gov/emeu/states/sep_fuel/html/fuel_mg.html\#footnotes, accessed Oct. 2003.

EPA: U.S. Environmental Protection Agency

EPA, 2004, spreadsheets provided by John Koupal, U.S. Environmental Protection Agency, August 2004. [Also see E.H. Pechan \& Associates, 2004, "Documentation for the Onroad National Emissions Inventory (NEI) for Base Years 1970-2002,” Springfield, Va., Jan.]

EV World, 2004, "California Governor's Energy Plan Boasts 'Hydrogen Highway' by 2010," Jan. 4.

Greene, D., et al., 2004, "Hydrogen Transition Modeling and Analysis: HYTRANS V 1.0," presented to U.S. Department of Energy, Washington, D.C., May 10.

Kansas Turnpike Authority, 2003, http://ksturnpike.com/services.html, accessed Sept. 2003. 
Mann, M., 2004, "Moving toward Consistent Analysis in the HFCIT Program: H2A," presented at the National Hydrogen Association Meeting, 2004, Los Angeles, Calif., April 26-30, available at http://www.eere.energy.gov/hydrogenandfuelcells/analysis/model.html

Maples, J., 2004, Energy Information Administration, personal communication, Dec. 22.

Melaina, M.W., 2003, "Initiating Hydrogen Infrastructures: Preliminary Analysis of a Sufficient Number of Initial Hydrogen Stations on the US," International Journal of Hydrogen Energy 28:743-755.

Myers, D.B., et al., 2003, "Hydrogen from Renewable Energy Sources: Pathway to 10 Quads for Transportation Uses in 2030 to 2050," prepared by Directed Technologies, Inc., Arlington, Va., for DOE, Oct.

NMA: National Mining Association

NMA, 2004a, http://www.nma.org/pdf/c_use_state.pdf National Mining Association, accessed Jan. 2004.

NMA, 2004b, http://www.nma.org/pdf/c_production.pdf, National Mining Association, accessed Jan. 2004.

NREL: National Renewable Energy Laboratory

NREL, 2003, http://maps.nrel.gov/annualdir.html, solar resource estimates, accessed Oct. 2003.

Ohio Turnpike, 2003, http://www.ohioturnpike.org/services.html, accessed Sept. 2003.

Oil and Gas Journal, 2003, "U.S. Pipeline Companies Solidly Profitable in 2002, Scale Back Construction Plans," Sept. 8.

Oil and Gas Journal, 2001, "Pipeline Economics: Profitable 2000, Higher Demand Pushes U.S. Natural Gas Construction Plans," Sept. 3.

Oil and Gas Journal, 1999, "U.S. Pipelines Experience Another Tight Year, Reflect Merger Frenzy," Aug. 23.

ORC International (2004), CARAVAN Services, Surveys of 1000 Households during May 20, 2004, for National Renewable Energy Laboratory, Golden, Colo.

ORNL: Oak Ridge National Laboratory

ORNL, 2003, http://bioenergy.ornl.gov/resourcedata/index.html, Biomass Feedstock Availability in the United States: 1999 State Level Analysis, accessed Oct. 2003. 
Patterson, P., et al., 2003, "Joint DOE/NRCAN Study of North American Transportation Energy Futures: Discussion of the Study, Presentation of Phase 2 Results (May 2003)," presented to U.S. Department of Energy, Washington, D.C., April 17.

Pennsylvania Turnpike, 2003, http://www.paturnpike.com/travelmap/simpmap.aspx, accessed Sept. 2003.

R.S. Means Construction Cost Estimating Guide, 2002. Kingston, Mass.

SFA Pacific, Inc., 2002, Hydrogen Supply: Cost Estimate for Hydrogen Pathways-Scoping Analysis, NREL/SR-540-32525, National Renewable Energy Laboratory, Golden, Colo., July.

Singh, M., A. Vyas, and E. Steiner, 2003, VISION Model: Description of Model Used to Estimate the Impact of Highway Vehicle Technologies and Fuels on Energy Use and Carbon Emissions to 2050, ANL/ESD/04-1, Argonne National Laboratory, Argonne, Ill., Dec.

Singh, M. (Argonne National Laboratory), J. Moore (TA Engineering ), S. Plotkin (Argonne National Laboratory) and P. Patterson (DOE), 2004, meeting at U.S. Department of Energy, Washington, D.C., April.

U.S. Census Bureau, 2002, Metropolitan Areas and Components, 1999, with FIPS Codes, Washington, D.C., Jan.

U.S. Census Bureau, 2000, 1997 Economic Census: Retail Trade Geographic Series, EC97R44A-US(RV) (also see individual state reports), Washington, D.C., March, available at http://www.census.gov/prod/ec97/97r44-us.pdf.

Woods, F., 2005, "NEMS-H2 Design Discussion Topics," presented to U.S. Department of Energy, Washington, D.C., Jan. 27.

Yeh, S., and D. Loughlin, 2005, "An Integrated Hydrogen Scenario Analysis: Impacts on Transportation, Energy Use and Air Emissions," presented at the NHA Annual Hydrogen Conference, Washington, D.C., March 31. 


\section{APPENDIX A: COST ESTIMATES BY RESOURCE FUEL INPUT TO REGIONAL $\mathrm{H}_{2}$ MODEL}

Table A.1 Centralized Production, Delivery, and Dispensing of $\mathrm{H}_{2}$ Using Natural Gas (by Region)

Table A.2 Centralized Production, Delivery, and Dispensing of $\mathrm{H}_{2}$ Using Coal with Carbon Sequestration (by Region)

Table A.3 Centralized Production, Delivery, and Dispensing of $\mathrm{H}_{2}$ Using Biomass (by Region)

Table A.4 Centralized Production, Delivery, and Dispensing of $\mathrm{H}_{2}$ via Electrolysis

Table A.5 Distributed Hydrogen Production and Dispensing Using Natural Gas (by Region)

Table A.6 Distributed Hydrogen Production and Dispensing Using Electrolysis (Detailed Results for Selected Regions)

Table A.7 Distributed Hydrogen Production and Dispensing Using Electrolysis (Summary Results for Selected Regions) 
Table A.1 Centralized Production, Delivery, and Dispensing of $\mathrm{H}_{2}$ Using Natural Gas

Hydrogen Production, Dispensing, and Delivery Cost Estimates, SMR-New England

\begin{tabular}{ccccccc}
\hline & $\begin{array}{c}\text { Hydrogen } \\
\text { Production } \\
\text { Cost, } \\
\text { (\$/GEG) }\end{array}$ & $\begin{array}{c}\text { Carbon } \\
\text { Sequestration }\end{array}$ & $\begin{array}{c}\text { Delivery Cost } \\
\text { (\$/GEG) }\end{array}$ & $\begin{array}{c}\text { Dispensing } \\
\text { Cost }\end{array}$ & $\begin{array}{c}\text { Total } \\
\text { Hydrogen } \\
\text { Cost } \\
\text { (\$/GEG) }\end{array}$ & Comments \\
\hline 2010 & 2.35 & 0.00 & 0.05 & 1.13 & 3.52 & Delivered via Cryo-Tanker \\
2020 & 1.48 & 0.00 & 0.05 & 0.99 & 2.51 & Delivered via Cryo-Tanker \\
2030 & 2.62 & 0.00 & 0.05 & 0.86 & 3.52 & Delivered via Cryo-Tanker \\
2040 & 2.21 & 0.00 & 0.05 & 0.72 & 2.98 & Delivered via Cryo-Tanker \\
2050 & 2.93 & 0.00 & 0.05 & 0.52 & 3.50 & Delivered via Cryo-Tanker \\
\hline
\end{tabular}

Hydrogen Production, Dispensing, and Delivery Cost Estimates, SMR-Middle Atlantic Region

\begin{tabular}{ccccccc}
\hline & $\begin{array}{c}\text { Hydrogen } \\
\text { Production } \\
\text { Cost, } \\
\text { (\$/GEG) }\end{array}$ & $\begin{array}{c}\text { Carbon } \\
\text { Sequestration }\end{array}$ & $\begin{array}{c}\text { Delivery Cost } \\
\text { (\$/GEG) }\end{array}$ & $\begin{array}{c}\text { Dispensing } \\
\text { Cost }\end{array}$ & $\begin{array}{c}\text { Total } \\
\text { Hydrogen } \\
\text { Cost } \\
\text { (\$/GEG) }\end{array}$ & Comments \\
\hline 2010 & 2.29 & 0.00 & 0.03 & 1.13 & 3.45 & Delivered via Cryo-Tanker \\
2020 & 2.43 & 0.00 & 0.03 & 0.99 & 3.46 & Delivered via Cryo-Tanker \\
2030 & 2.52 & 0.00 & 0.03 & 0.86 & 3.41 & Delivered via Cryo-Tanker \\
2040 & 2.61 & 0.00 & 0.03 & 0.72 & 3.37 & Delivered via Cryo-Tanker \\
2050 & 2.71 & 0.00 & 0.03 & 0.52 & 3.27 & Delivered via Cryo-Tanker \\
\hline
\end{tabular}

Hydrogen Production, Dispensing, and Delivery Cost Estimates, SMR-East North Central Region

\begin{tabular}{ccccccc}
\hline & $\begin{array}{c}\text { Hydrogen } \\
\text { Production } \\
\text { Cost, } \\
\text { Y\$/GEG) }\end{array}$ & $\begin{array}{c}\text { Carbon } \\
\text { Sequestration }\end{array}$ & $\begin{array}{c}\text { Delivery Cost } \\
\text { (\$/GEG) }\end{array}$ & $\begin{array}{c}\text { Dispensing } \\
\text { Cost }\end{array}$ & $\begin{array}{c}\text { Total } \\
\text { Hydrogen } \\
\text { Cost } \\
\text { (\$/GEG) }\end{array}$ & Comments \\
\hline 2010 & 2.09 & 0.00 & 0.07 & 1.13 & 3.29 & Delivered via Cryo-Tanker \\
2020 & 2.20 & 0.00 & 0.07 & 0.99 & 3.26 & Delivered via Cryo-Tanker \\
2030 & 2.29 & 0.00 & 0.07 & 0.86 & 3.21 & Delivered via Cryo-Tanker \\
2040 & 2.38 & 0.00 & 0.07 & 0.72 & 3.17 & Delivered via Cryo-Tanker \\
2050 & 2.49 & 0.00 & 0.07 & 0.52 & 3.08 & Delivered via Cryo-Tanker \\
\hline
\end{tabular}


Table A.1 (Cont.)

Hydrogen Production, Dispensing, and Delivery Cost Estimates, SMR-West North Central Region

\begin{tabular}{ccccccc}
\hline & $\begin{array}{c}\text { Hydrogen } \\
\text { Production } \\
\text { Cost, } \\
\text { (\$/GEG) }\end{array}$ & $\begin{array}{c}\text { Carbon } \\
\text { Sequestration }\end{array}$ & $\begin{array}{c}\text { Delivery Cost } \\
\text { (\$/GEG) }\end{array}$ & $\begin{array}{c}\text { Dispensing } \\
\text { Cost }\end{array}$ & $\begin{array}{c}\text { Total } \\
\text { Hydrogen } \\
\text { Cost } \\
\text { (\$/GEG) }\end{array}$ & Comments \\
\hline 2010 & 2.13 & 0.00 & 0.29 & 1.13 & 3.54 & Delivered via Cryo-Tanker \\
2020 & 2.19 & 0.00 & 0.29 & 0.99 & 3.47 & Delivered via Cryo-Tanker \\
2030 & 2.32 & 0.00 & 0.29 & 0.86 & 3.47 & Delivered via Cryo-Tanker \\
2040 & 2.47 & 0.00 & 0.29 & 0.72 & 3.49 & Delivered via Cryo-Tanker \\
2050 & 2.65 & 0.00 & 0.29 & 0.52 & 3.46 & Delivered via Cryo-Tanker \\
\hline
\end{tabular}

Hydrogen Production, Dispensing, and Delivery Cost Estimates, SMR-South Atlantic

\begin{tabular}{ccccccc}
\hline Hydrogen & $\begin{array}{c}\text { c } \\
\text { Production } \\
\text { Cost, } \\
\text { Year }\end{array}$ & $\begin{array}{c}\text { Carbon } \\
\text { Sequestration }\end{array}$ & $\begin{array}{c}\text { Delivery Cost } \\
\text { (\$/GEG) }\end{array}$ & $\begin{array}{c}\text { Total } \\
\text { Dispensing } \\
\text { Cost }\end{array}$ & $\begin{array}{c}\text { Hydrogen } \\
\text { Cost } \\
\text { (\$/GEG) }\end{array}$ & Comments \\
\hline 2010 & 2.06 & 0.00 & 0.07 & 1.13 & 3.25 & Delivered via Cryo-Tanker \\
2020 & 2.15 & 0.00 & 0.07 & 0.99 & 3.21 & Delivered via Cryo-Tanker \\
2030 & 2.20 & 0.00 & 0.07 & 0.86 & 3.12 & Delivered via Cryo-Tanker \\
2040 & 2.25 & 0.00 & 0.07 & 0.72 & 3.04 & Delivered via Cryo-Tanker \\
2050 & 2.31 & 0.00 & 0.07 & 0.52 & 2.89 & Delivered via Cryo-Tanker \\
\hline
\end{tabular}

Hydrogen Production, Dispensing, and Delivery Cost Estimates, SMR-East South Central Region

\begin{tabular}{ccccccc}
\hline & $\begin{array}{c}\text { Hydrogen } \\
\text { Production } \\
\text { Cost, } \\
\text { (\$/GEG) }\end{array}$ & $\begin{array}{c}\text { Carbon } \\
\text { Sequestration }\end{array}$ & $\begin{array}{c}\text { Delivery Cost } \\
\text { (\$/GEG) }\end{array}$ & $\begin{array}{c}\text { Dispensing } \\
\text { Cost }\end{array}$ & $\begin{array}{c}\text { Total } \\
\text { Hydrogen } \\
\text { Cost } \\
\text { (\$/GEG) }\end{array}$ & Comments \\
\hline 2010 & 2.02 & 0.00 & 0.10 & 1.13 & 3.25 & Delivered via Cryo-Tanker \\
2020 & 2.12 & 0.00 & 0.10 & 0.99 & 3.21 & Delivered via Cryo-Tanker \\
2030 & 2.16 & 0.00 & 0.10 & 0.86 & 3.12 & Delivered via Cryo-Tanker \\
2040 & 2.21 & 0.00 & 0.10 & 0.72 & 3.04 & Delivered via Cryo-Tanker \\
2050 & 2.26 & 0.00 & 0.10 & 0.52 & 2.88 & Delivered via Cryo-Tanker \\
\hline
\end{tabular}


Table A.1 (Cont.)

Hydrogen Production, Dispensing, and Delivery Cost Estimates, SMR-West South Central Region

\begin{tabular}{ccccccc}
\hline & $\begin{array}{c}\text { Hydrogen } \\
\text { Production } \\
\text { Cost, } \\
\text { (\$/GEG) }\end{array}$ & $\begin{array}{c}\text { Carbon } \\
\text { Sequestration }\end{array}$ & $\begin{array}{c}\text { Delivery Cost } \\
\text { (\$/GEG) }\end{array}$ & $\begin{array}{c}\text { Dispensing } \\
\text { Cost }\end{array}$ & $\begin{array}{c}\text { Total } \\
\text { Hydrogen } \\
\text { Cost } \\
\text { (\$/GEG) }\end{array}$ & Comments \\
\hline 2010 & 2.03 & 0.00 & 0.14 & 1.13 & 3.30 & Delivered via Cryo-Tanker \\
2020 & 2.13 & 0.00 & 0.14 & 0.99 & 3.26 & Delivered via Cryo-Tanker \\
2030 & 2.22 & 0.00 & 0.14 & 0.86 & 3.21 & Delivered via Cryo-Tanker \\
2040 & 2.31 & 0.00 & 0.14 & 0.72 & 3.17 & Delivered via Cryo-Tanker \\
2050 & 2.41 & 0.00 & 0.14 & 0.52 & 3.07 & Delivered via Cryo-Tanker \\
\hline
\end{tabular}

Hydrogen Production, Dispensing, and Delivery Cost Estimates, SMR-Mountain

\begin{tabular}{|c|c|c|c|c|c|c|}
\hline Year & $\begin{array}{c}\text { Hydrogen } \\
\text { Production } \\
\text { Cost, } \\
\text { (\$/GEG) } \\
\end{array}$ & $\begin{array}{c}\text { Carbon } \\
\text { Sequestration }\end{array}$ & $\begin{array}{c}\text { Delivery Cost } \\
\text { (\$/GEG) }\end{array}$ & $\begin{array}{c}\text { Dispensing } \\
\text { Cost }\end{array}$ & $\begin{array}{c}\text { Total } \\
\text { Hydrogen } \\
\text { Cost } \\
\text { (\$/GEG) }\end{array}$ & Comments \\
\hline 2010 & 2.08 & 0.00 & 0.51 & 1.13 & 3.72 & Delivered via Cryo-Tanker \\
\hline 2020 & 1.07 & 0.00 & 0.51 & 0.83 & 2.42 & Delivered via Cryo-Tanker \\
\hline 2030 & 1.23 & 0.00 & 0.51 & 0.72 & 2.47 & Delivered via Cryo-Tanker \\
\hline 2040 & 1.43 & 0.00 & 0.51 & 0.61 & 2.55 & Delivered via Cryo-Tanker \\
\hline 2050 & 1.67 & 0.00 & 0.51 & 0.44 & 2.61 & Delivered via Cryo-Tanker \\
\hline
\end{tabular}

Hydrogen Production, Dispensing, and Delivery Cost Estimates, SMR-Pacific

\begin{tabular}{|c|c|c|c|c|c|c|}
\hline Year & $\begin{array}{c}\text { Hydrogen } \\
\text { Production } \\
\text { Cost, } \\
\text { (\$/GEG) } \\
\end{array}$ & $\begin{array}{c}\text { Carbon } \\
\text { Sequestration } \\
\end{array}$ & $\begin{array}{c}\text { Delivery Cost } \\
\text { (\$/GEG) }\end{array}$ & $\begin{array}{c}\text { Dispensing } \\
\text { Cost }\end{array}$ & $\begin{array}{c}\text { Total } \\
\text { Hydrogen } \\
\text { Cost } \\
(\$ / \text { GEG) } \\
\end{array}$ & Comments \\
\hline 2010 & 2.45 & 0.00 & 0.12 & 1.13 & 3.69 & Delivered via Cryo-Tanker \\
\hline 2020 & 2.40 & 0.00 & 0.12 & 0.99 & 3.51 & Delivered via Cryo-Tanker \\
\hline 2030 & 2.52 & 0.00 & 0.12 & 0.86 & 3.50 & Delivered via Cryo-Tanker \\
\hline 2040 & 2.69 & 0.00 & 0.12 & 0.72 & 3.53 & Delivered via Cryo-Tanker \\
\hline 2050 & 2.90 & 0.00 & 0.12 & 0.52 & 3.54 & Delivered via Cryo-Tanker \\
\hline
\end{tabular}


Table A.2 Centralized Production, Delivery, and Dispensing of $\mathrm{H}_{2}$ Using Coal with Carbon Sequestration

Hydrogen Production, Dispensing, and Delivery Cost Estimates, Coal Gasification-New England

\begin{tabular}{|c|c|c|c|c|c|c|}
\hline Year & $\begin{array}{c}\text { Hydrogen } \\
\text { Production } \\
\text { Cost, } \\
\text { (\$/GEG) } \\
\end{array}$ & $\begin{array}{c}\text { Carbon } \\
\text { Sequestration }\end{array}$ & $\begin{array}{c}\text { Delivery Cost } \\
\text { (\$/GEG) }\end{array}$ & $\begin{array}{c}\text { Dispensing } \\
\text { Cost }\end{array}$ & $\begin{array}{c}\text { Total } \\
\text { Hydrogen } \\
\text { Cost } \\
\text { (\$/GEG) } \\
\end{array}$ & Comments \\
\hline 2010 & 3.21 & 0.64 & 0.05 & 1.13 & 5.02 & Cryogenic Tanker Delivery \\
\hline 2020 & 1.87 & 0.37 & 0.49 & 0.91 & 3.64 & $\begin{array}{l}\text { Mixed Cryo + Pipeline Delivery } \\
(50 \% \text { each })\end{array}$ \\
\hline 2030 & 1.64 & 0.33 & 0.23 & 0.72 & 2.92 & Pipeline Delivery \\
\hline 2040 & 1.56 & 0.31 & 0.08 & 0.61 & 2.56 & Pipeline Delivery \\
\hline 2050 & 1.49 & 0.30 & 0.07 & 0.44 & 2.30 & Pipeline Delivery \\
\hline
\end{tabular}

Hydrogen Production, Dispensing, and Delivery Cost Estimates, Coal Gasification-Middle Atlantic Region

\begin{tabular}{ccccccl}
\hline Year & $\begin{array}{c}\text { Hydrogen } \\
\text { Production } \\
\text { Cost, } \\
\text { (\$/GEG) }\end{array}$ & $\begin{array}{c}\text { Carbon } \\
\text { Sequestration }\end{array}$ & $\begin{array}{c}\text { Delivery Cost } \\
\text { (\$/GEG) }\end{array}$ & $\begin{array}{c}\text { Dispensing } \\
\text { Cost }\end{array}$ & $\begin{array}{c}\text { Total } \\
\text { Hydrogen } \\
\text { Cost } \\
\text { (\$/GEG) }\end{array}$ & \multicolumn{1}{c}{ Comments } \\
\hline 2010 & 2.89 & 0.58 & 0.03 & 1.13 & 4.63 & Cryogenic Tanker Delivery \\
2020 & 1.66 & 0.33 & 0.36 & 0.91 & 3.26 & $\begin{array}{l}\text { Mixed Cryo + Pipeline Delivery } \\
\text { (50\% each) }\end{array}$ \\
2030 & 1.46 & 0.29 & 0.17 & 0.72 & 2.64 & Pipeline Delivery \\
2040 & 1.39 & 0.28 & 0.06 & 0.61 & 2.34 & Pipeline Delivery \\
2050 & 1.33 & 0.27 & 0.05 & 0.44 & 2.09 & Pipeline Delivery \\
\hline
\end{tabular}

Hydrogen Production, Dispensing, and Delivery Cost Estimates, Coal Gasification-East North Central Region

\begin{tabular}{|c|c|c|c|c|c|c|}
\hline Year & $\begin{array}{c}\text { Hydrogen } \\
\text { Production } \\
\text { Cost, } \\
\text { (\$/GEG) } \\
\end{array}$ & $\begin{array}{c}\text { Carbon } \\
\text { Sequestration }\end{array}$ & $\begin{array}{c}\text { Delivery Cost } \\
(\$ / G E G)\end{array}$ & $\begin{array}{c}\text { Dispensing } \\
\text { Cost }\end{array}$ & $\begin{array}{c}\text { Total } \\
\text { Hydrogen } \\
\text { Cost } \\
\text { (\$/GEG) } \\
\end{array}$ & Comments \\
\hline 2010 & 2.79 & 0.56 & 0.07 & 1.13 & 4.54 & Cryogenic Tanker Delivery \\
\hline 2020 & 1.62 & 0.32 & 0.66 & 0.91 & 3.51 & $\begin{array}{l}\text { Mixed Cryo + Pipeline Delivery } \\
(50 \% \text { each })\end{array}$ \\
\hline 2030 & 1.41 & 0.28 & 0.31 & 0.72 & 2.73 & Pipeline Delivery \\
\hline 2040 & 1.34 & 0.27 & 0.11 & 0.61 & 2.32 & Pipeline Delivery \\
\hline 2050 & 1.27 & 0.25 & 0.10 & 0.44 & 2.06 & Pipeline Delivery \\
\hline
\end{tabular}


Table A.2 (Cont.)

Hydrogen Production, Dispensing, and Delivery Cost Estimates, Coal Gasification-West North Central Region

\begin{tabular}{|c|c|c|c|c|c|c|}
\hline Year & $\begin{array}{c}\text { Hydrogen } \\
\text { Production } \\
\text { Cost, } \\
\text { (\$/GEG) } \\
\end{array}$ & $\begin{array}{c}\text { Carbon } \\
\text { Sequestration }\end{array}$ & $\begin{array}{c}\text { Delivery Cost } \\
\text { (\$/GEG) }\end{array}$ & $\begin{array}{c}\text { Dispensing } \\
\text { Cost }\end{array}$ & $\begin{array}{c}\text { Total } \\
\text { Hydrogen } \\
\text { Cost } \\
\text { (\$/GEG) } \\
\end{array}$ & Comments \\
\hline 2010 & 2.75 & 0.55 & 0.29 & 1.13 & 4.72 & Cryogenic Tanker Delivery \\
\hline 2020 & 1.57 & 0.31 & 2.75 & 0.91 & 5.54 & $\begin{array}{l}\text { Mixed Cryo + Pipeline Delivery } \\
(50 \% \text { each })\end{array}$ \\
\hline 2030 & 1.37 & 0.27 & 1.31 & 0.72 & 3.67 & Pipeline Delivery \\
\hline 2040 & 1.30 & 0.26 & 0.45 & 0.61 & 2.63 & Pipeline Delivery \\
\hline 2050 & 1.25 & 0.25 & 0.40 & 0.44 & 2.33 & Pipeline Delivery \\
\hline
\end{tabular}

Hydrogen Production, Dispensing, and Delivery Cost Estimates, Coal Gasification-South Atlantic

\begin{tabular}{|c|c|c|c|c|c|c|}
\hline Year & $\begin{array}{c}\text { Hydrogen } \\
\text { Production } \\
\text { Cost, } \\
\text { (\$/GEG) }\end{array}$ & $\begin{array}{c}\text { Carbon } \\
\text { Sequestration }\end{array}$ & $\begin{array}{c}\text { Delivery Cost } \\
\text { (\$/GEG) }\end{array}$ & $\begin{array}{c}\text { Dispensing } \\
\text { Cost }\end{array}$ & $\begin{array}{c}\text { Total } \\
\text { Hydrogen } \\
\text { Cost } \\
(\$ / \text { GEG) } \\
\end{array}$ & Comments \\
\hline 2010 & 2.86 & 0.57 & 0.07 & 1.13 & 4.63 & Cryogenic Tanker Delivery \\
\hline 2020 & 1.66 & 0.33 & 0.56 & 0.91 & 3.47 & $\begin{array}{l}\text { Mixed Cryo + Pipeline Delivery } \\
(50 \% \text { each })\end{array}$ \\
\hline 2030 & 1.46 & 0.29 & 0.26 & 0.72 & 2.73 & Pipeline Delivery \\
\hline 2040 & 1.38 & 0.28 & 0.09 & 0.61 & 2.36 & Pipeline Delivery \\
\hline 2050 & 1.32 & 0.26 & 0.08 & 0.44 & 2.10 & Pipeline Delivery \\
\hline
\end{tabular}

Hydrogen Production, Dispensing, and Delivery Cost Estimates, Coal Gasification-East South Central Region

\begin{tabular}{|c|c|c|c|c|c|c|}
\hline Year & $\begin{array}{c}\text { Hydrogen } \\
\text { Production } \\
\text { Cost, } \\
\text { (\$/GEG) } \\
\end{array}$ & $\begin{array}{c}\text { Carbon } \\
\text { Sequestration }\end{array}$ & $\begin{array}{c}\text { Delivery Cost } \\
\text { (\$/GEG) }\end{array}$ & $\begin{array}{c}\text { Dispensing } \\
\text { Cost }\end{array}$ & $\begin{array}{c}\text { Total } \\
\text { Hydrogen } \\
\text { Cost } \\
\text { (\$/GEG) } \\
\end{array}$ & Comments \\
\hline 2010 & 2.79 & 0.56 & 0.10 & 1.13 & 4.58 & Cryogenic Tanker Delivery \\
\hline 2020 & 1.62 & 0.32 & 0.84 & 0.91 & 3.69 & $\begin{array}{l}\text { Mixed Cryo + Pipeline Delivery } \\
(50 \% \text { each })\end{array}$ \\
\hline 2030 & 1.41 & 0.28 & 0.40 & 0.72 & 2.81 & Pipeline Delivery \\
\hline 2040 & 1.34 & 0.27 & 0.14 & 0.61 & 2.36 & Pipeline Delivery \\
\hline 2050 & 1.28 & 0.26 & 0.12 & 0.44 & 2.10 & Pipeline Delivery \\
\hline
\end{tabular}


Table A.2 (Cont.)

Hydrogen Production, Dispensing, and Delivery Cost Estimates, Coal Gasification-West South Central Region

\begin{tabular}{|c|c|c|c|c|c|c|}
\hline Year & $\begin{array}{c}\text { Hydrogen } \\
\text { Production } \\
\text { Cost, } \\
\text { (\$/GEG) } \\
\end{array}$ & $\begin{array}{c}\text { Carbon } \\
\text { Sequestration }\end{array}$ & $\begin{array}{c}\text { Delivery Cost } \\
\text { (\$/GEG) }\end{array}$ & $\begin{array}{c}\text { Dispensing } \\
\text { Cost }\end{array}$ & $\begin{array}{c}\text { Total } \\
\text { Hydrogen } \\
\text { Cost } \\
\text { (\$/GEG) } \\
\end{array}$ & Comments \\
\hline 2010 & 2.78 & 0.56 & 0.14 & 1.13 & 4.60 & Cryogenic Tanker Delivery \\
\hline 2020 & 1.59 & 0.32 & 1.10 & 0.91 & 3.92 & $\begin{array}{l}\text { Mixed Cryo + Pipeline Delivery } \\
(50 \% \text { each })\end{array}$ \\
\hline 2030 & 1.41 & 0.28 & 0.52 & 0.72 & 2.93 & Pipeline Delivery \\
\hline 2040 & 1.35 & 0.27 & 0.18 & 0.61 & 2.41 & Pipeline Delivery \\
\hline 2050 & 1.31 & 0.26 & 0.16 & 0.44 & 2.17 & Pipeline Delivery \\
\hline
\end{tabular}

Hydrogen Production, Dispensing, and Delivery Cost Estimates, Coal Gasification-Mountain

\begin{tabular}{|c|c|c|c|c|c|c|}
\hline Year & $\begin{array}{c}\text { Hydrogen } \\
\text { Production } \\
\text { Cost, } \\
\text { (\$/GEG) } \\
\end{array}$ & $\begin{array}{c}\text { Carbon } \\
\text { Sequestration }\end{array}$ & $\begin{array}{c}\text { Delivery Cost } \\
(\$ / \text { GEG })\end{array}$ & $\begin{array}{c}\text { Dispensing } \\
\text { Cost }\end{array}$ & $\begin{array}{c}\text { Total } \\
\text { Hydrogen } \\
\text { Cost } \\
\text { (\$/GEG) } \\
\end{array}$ & Comments \\
\hline 2010 & 2.79 & 0.56 & 0.51 & 1.13 & 4.99 & Cryogenic Tanker Delivery \\
\hline 2020 & 1.60 & 0.32 & 4.59 & 0.91 & 7.42 & $\begin{array}{l}\text { Mixed Cryo + Pipeline Delivery } \\
(50 \% \text { each })\end{array}$ \\
\hline 2030 & 1.40 & 0.28 & 2.18 & 0.72 & 4.58 & Pipeline Delivery \\
\hline 2040 & 1.33 & 0.27 & 0.75 & 0.61 & 2.96 & Pipeline Delivery \\
\hline 2050 & 1.27 & 0.25 & 0.67 & 0.44 & 2.63 & Pipeline Delivery \\
\hline
\end{tabular}

Hydrogen Production, Dispensing, and Delivery Cost Estimates, Coal Gasification-Pacific

\begin{tabular}{|c|c|c|c|c|c|c|}
\hline Year & $\begin{array}{c}\text { Hydrogen } \\
\text { Production } \\
\text { Cost, } \\
\text { (\$/GEG) } \\
\end{array}$ & $\begin{array}{c}\text { Carbon } \\
\text { Sequestration }\end{array}$ & $\begin{array}{c}\text { Delivery Cost } \\
\text { (\$/GEG) }\end{array}$ & $\begin{array}{c}\text { Dispensing } \\
\text { Cost }\end{array}$ & $\begin{array}{c}\text { Total } \\
\text { Hydrogen } \\
\text { Cost } \\
\text { (\$/GEG) } \\
\end{array}$ & Comments \\
\hline 2010 & 3.34 & 0.67 & 0.12 & 1.13 & 5.25 & Cryogenic Tanker Delivery \\
\hline 2020 & 1.79 & 0.36 & 1.22 & 0.91 & 4.28 & $\begin{array}{l}\text { Mixed Cryo + Pipeline Delivery } \\
(50 \% \text { each })\end{array}$ \\
\hline 2030 & 1.55 & 0.31 & 0.59 & 0.72 & 3.16 & Pipeline Delivery \\
\hline 2040 & 1.45 & 0.29 & 0.20 & 0.61 & 2.55 & Pipeline Delivery \\
\hline 2050 & 1.36 & 0.27 & 0.18 & 0.44 & 2.25 & Pipeline Delivery \\
\hline
\end{tabular}


Table A.3 Centralized Production, Delivery, and Dispensing of $\mathrm{H}_{2}$ Using Biomass

Hydrogen Production, Dispensing, and Delivery Cost Estimates, Biomass Gasification-New England

\begin{tabular}{|c|c|c|c|c|c|c|}
\hline Year & $\begin{array}{c}\text { Hydrogen } \\
\text { Production } \\
\text { Cost, } \\
\text { (\$/GEG) } \\
\end{array}$ & $\begin{array}{c}\text { Carbon } \\
\text { Sequestration }\end{array}$ & $\begin{array}{c}\text { Delivery Cost } \\
\text { (\$/GEG) }\end{array}$ & $\begin{array}{c}\text { Dispensing } \\
\text { Cost }\end{array}$ & $\begin{array}{c}\text { Total } \\
\text { Hydrogen } \\
\text { Cost } \\
\text { (\$/GEG) } \\
\end{array}$ & Comments \\
\hline 2010 & 3.51 & 0.00 & 0.05 & 1.13 & 4.68 & Cryogenic Tanker Delivery \\
\hline 2020 & 2.08 & 0.00 & 0.49 & 0.91 & 3.48 & $\begin{array}{l}\text { Mixed Cryo + Pipeline Delivery } \\
(50 \% \text { each })\end{array}$ \\
\hline 2030 & 1.83 & 0.00 & 0.23 & 0.72 & 2.78 & Pipeline Delivery \\
\hline 2040 & 1.83 & 0.00 & 0.08 & 0.61 & 2.52 & Pipeline Delivery \\
\hline 2050 & 1.84 & 0.00 & 0.07 & 0.44 & 2.35 & Pipeline Delivery \\
\hline
\end{tabular}

Hydrogen Production, Dispensing, and Delivery Cost Estimates, Biomass Gasification-Middle Atlantic Region

\begin{tabular}{|c|c|c|c|c|c|c|}
\hline Year & $\begin{array}{c}\text { Hydrogen } \\
\text { Production } \\
\text { Cost, } \\
\text { (\$/GEG) }\end{array}$ & $\begin{array}{c}\text { Carbon } \\
\text { Sequestration }\end{array}$ & $\begin{array}{c}\text { Delivery Cost } \\
\text { (\$/GEG) }\end{array}$ & $\begin{array}{c}\text { Dispensing } \\
\text { Cost }\end{array}$ & $\begin{array}{c}\text { Total } \\
\text { Hydrogen } \\
\text { Cost } \\
(\$ / G E G) \\
\end{array}$ & Comments \\
\hline 2010 & 3.37 & 0.00 & 0.03 & 1.13 & 4.53 & Cryogenic Tanker Delivery \\
\hline 2020 & 2.04 & 0.00 & 0.36 & 0.91 & 3.31 & $\begin{array}{l}\text { Mixed Cryo + Pipeline Delivery } \\
(50 \% \text { each })\end{array}$ \\
\hline 2030 & 1.78 & 0.00 & 0.17 & 0.72 & 2.67 & Pipeline Delivery \\
\hline 2040 & 1.77 & 0.00 & 0.06 & 0.61 & 2.44 & Pipeline Delivery \\
\hline 2050 & 1.77 & 0.00 & 0.05 & 0.44 & 2.26 & Pipeline Delivery \\
\hline
\end{tabular}

Hydrogen Production, Dispensing, and Delivery Cost Estimates, Biomass Gasification-East North Central Region

\begin{tabular}{|c|c|c|c|c|c|c|}
\hline Year & $\begin{array}{c}\text { Hydrogen } \\
\text { Production } \\
\text { Cost, } \\
\text { (\$/GEG) } \\
\end{array}$ & $\begin{array}{c}\text { Carbon } \\
\text { Sequestration }\end{array}$ & $\begin{array}{c}\text { Delivery Cost } \\
(\$ / G E G)\end{array}$ & $\begin{array}{c}\text { Dispensing } \\
\text { Cost }\end{array}$ & $\begin{array}{c}\text { Total } \\
\text { Hydrogen } \\
\text { Cost } \\
\text { (\$/GEG) } \\
\end{array}$ & Comments \\
\hline 2010 & 3.23 & 0.00 & 0.07 & 1.13 & 4.42 & Cryogenic Tanker Delivery \\
\hline 2020 & 1.97 & 0.00 & 0.66 & 0.91 & 3.53 & $\begin{array}{l}\text { Mixed Cryo + Pipeline Delivery } \\
(50 \% \text { each })\end{array}$ \\
\hline 2030 & 1.71 & 0.00 & 0.31 & 0.72 & 2.74 & Pipeline Delivery \\
\hline 2040 & 1.70 & 0.00 & 0.11 & 0.61 & 2.42 & Pipeline Delivery \\
\hline 2050 & 1.69 & 0.00 & 0.10 & 0.44 & 2.23 & Pipeline Delivery \\
\hline
\end{tabular}


Table A.3 (Cont.)

Hydrogen Production, Dispensing, and Delivery Cost Estimates, Biomass Gasification-West North Central Region

\begin{tabular}{|c|c|c|c|c|c|c|}
\hline Year & $\begin{array}{c}\text { Hydrogen } \\
\text { Production } \\
\text { Cost, } \\
\text { (\$/GEG) } \\
\end{array}$ & $\begin{array}{c}\text { Carbon } \\
\text { Sequestration }\end{array}$ & $\begin{array}{l}\text { Delivery Cost } \\
\text { (\$/GEG) }\end{array}$ & $\begin{array}{c}\text { Dispensing } \\
\text { Cost }\end{array}$ & $\begin{array}{c}\text { Total } \\
\text { Hydrogen } \\
\text { Cost } \\
\text { (\$/GEG) } \\
\end{array}$ & Comments \\
\hline 2010 & 3.21 & 0.00 & 0.29 & 1.13 & 4.62 & Cryogenic Tanker Delivery \\
\hline 2020 & 1.94 & 0.00 & 2.75 & 0.91 & 5.60 & $\begin{array}{l}\text { Mixed Cryo + Pipeline Delivery } \\
(50 \% \text { each) }\end{array}$ \\
\hline 2030 & 1.69 & 0.00 & 1.31 & 0.72 & 3.72 & Pipeline Delivery \\
\hline 2040 & 1.69 & 0.00 & 0.45 & 0.61 & 2.75 & Pipeline Delivery \\
\hline 2050 & 1.69 & 0.00 & 0.40 & 0.44 & 2.53 & Pipeline Delivery \\
\hline
\end{tabular}

Hydrogen Production, Dispensing, and Delivery Cost Estimates, Biomass Gasification-South Atlantic

\begin{tabular}{|c|c|c|c|c|c|c|}
\hline Year & $\begin{array}{c}\text { Hydrogen } \\
\text { Production } \\
\text { Cost, } \\
\text { (\$/GEG) }\end{array}$ & $\begin{array}{c}\text { Carbon } \\
\text { Sequestration }\end{array}$ & $\begin{array}{l}\text { Delivery Cost } \\
\text { (\$/GEG) }\end{array}$ & $\begin{array}{l}\text { Dispensing } \\
\text { Cost }\end{array}$ & $\begin{array}{c}\text { Total } \\
\text { Hydrogen } \\
\text { Cost } \\
\text { (\$/GEG) }\end{array}$ & Comments \\
\hline 2010 & 3.22 & 0.00 & 0.07 & 1.13 & 4.41 & Cryogenic Tanker Delivery \\
\hline 2020 & 1.94 & 0.00 & 0.56 & 0.91 & 3.41 & $\begin{array}{l}\text { Mixed Cryo }+ \text { Pipeline Delivery } \\
(50 \% \text { each })\end{array}$ \\
\hline 2030 & 1.69 & 0.00 & 0.26 & 0.72 & 2.67 & Pipeline Delivery \\
\hline 2040 & 1.69 & 0.00 & 0.09 & 0.61 & 2.38 & Pipeline Delivery \\
\hline 2050 & 1.69 & 0.00 & 0.08 & 0.44 & 2.20 & Pipeline Delivery \\
\hline
\end{tabular}

Hydrogen Production, Dispensing, and Delivery Cost Estimates, Biomass Gasification-East South Central Region

\begin{tabular}{|c|c|c|c|c|c|c|}
\hline Year & $\begin{array}{c}\text { Hydrogen } \\
\text { Production } \\
\text { Cost, } \\
\text { (\$/GEG) } \\
\end{array}$ & $\begin{array}{c}\text { Carbon } \\
\text { Sequestration }\end{array}$ & $\begin{array}{c}\text { Delivery Cost } \\
(\$ / G E G)\end{array}$ & $\begin{array}{c}\text { Dispensing } \\
\text { Cost }\end{array}$ & $\begin{array}{c}\text { Total } \\
\text { Hydrogen } \\
\text { Cost } \\
\text { (\$/GEG) } \\
\end{array}$ & Comments \\
\hline 2010 & 3.20 & 0.00 & 0.10 & 1.13 & 4.43 & Cryogenic Tanker Delivery \\
\hline 2020 & 1.93 & 0.00 & 0.84 & 0.91 & 3.68 & $\begin{array}{l}\text { Mixed Cryo + Pipeline Delivery } \\
(50 \% \text { each })\end{array}$ \\
\hline 2030 & 1.69 & 0.00 & 0.40 & 0.72 & 2.80 & Pipeline Delivery \\
\hline 2040 & 1.68 & 0.00 & 0.14 & 0.61 & 2.43 & Pipeline Delivery \\
\hline 2050 & 1.68 & 0.00 & 0.12 & 0.44 & 2.24 & Pipeline Delivery \\
\hline
\end{tabular}


Table A.3 (Cont.)

Hydrogen Production, Dispensing, and Delivery Cost Estimates, Biomass Gasification-West South Central Region

\begin{tabular}{|c|c|c|c|c|c|c|}
\hline Year & $\begin{array}{c}\text { Hydrogen } \\
\text { Production } \\
\text { Cost, } \\
\text { (\$/GEG) } \\
\end{array}$ & $\begin{array}{c}\text { Carbon } \\
\text { Sequestration }\end{array}$ & $\begin{array}{l}\text { Delivery Cost } \\
\text { (\$/GEG) }\end{array}$ & $\begin{array}{c}\text { Dispensing } \\
\text { Cost }\end{array}$ & $\begin{array}{c}\text { Total } \\
\text { Hydrogen } \\
\text { Cost } \\
\text { (\$/GEG) } \\
\end{array}$ & Comments \\
\hline 2010 & 3.25 & 0.00 & 0.14 & 1.13 & 4.51 & Cryogenic Tanker Delivery \\
\hline 2020 & 1.97 & 0.00 & 1.10 & 0.91 & 3.98 & $\begin{array}{l}\text { Mixed Cryo + Pipeline Delivery } \\
(50 \% \text { each) }\end{array}$ \\
\hline 2030 & 1.73 & 0.00 & 0.52 & 0.72 & 2.98 & Pipeline Delivery \\
\hline 2040 & 1.75 & 0.00 & 0.18 & 0.61 & 2.53 & Pipeline Delivery \\
\hline 2050 & 1.77 & 0.00 & 0.16 & 0.44 & 2.36 & Pipeline Delivery \\
\hline
\end{tabular}

Hydrogen Production, Dispensing, and Delivery Cost Estimates, Biomass Gasification-Mountain

\begin{tabular}{|c|c|c|c|c|c|c|}
\hline Year & $\begin{array}{c}\text { Hydrogen } \\
\text { Production } \\
\text { Cost, } \\
\text { (\$/GEG) } \\
\end{array}$ & $\begin{array}{c}\text { Carbon } \\
\text { Sequestration }\end{array}$ & $\begin{array}{c}\text { Delivery Cost } \\
\text { (\$/GEG) }\end{array}$ & $\begin{array}{c}\text { Dispensing } \\
\text { Cost }\end{array}$ & $\begin{array}{c}\text { Total } \\
\text { Hydrogen } \\
\text { Cost } \\
\text { (\$/GEG) }\end{array}$ & Comments \\
\hline 2010 & 3.24 & 0.00 & 0.51 & 1.13 & 4.88 & Cryogenic Tanker Delivery \\
\hline 2020 & 1.96 & 0.00 & 4.59 & 0.91 & 7.46 & $\begin{array}{l}\text { Mixed Cryo + Pipeline Delivery } \\
(50 \% \text { each })\end{array}$ \\
\hline 2030 & 1.71 & 0.00 & 2.18 & 0.72 & 4.62 & Pipeline Delivery \\
\hline 2040 & 1.72 & 0.00 & 0.75 & 0.61 & 3.08 & Pipeline Delivery \\
\hline 2050 & 1.72 & 0.00 & 0.67 & 0.44 & 2.83 & Pipeline Delivery \\
\hline
\end{tabular}

Hydrogen Production, Dispensing, and Delivery Cost Estimates, Biomass Gasification-Pacific

\begin{tabular}{|c|c|c|c|c|c|c|}
\hline Year & $\begin{array}{c}\text { Hydrogen } \\
\text { Production } \\
\text { Cost, } \\
\text { (\$/GEG) } \\
\end{array}$ & $\begin{array}{c}\text { Carbon } \\
\text { Sequestration }\end{array}$ & $\begin{array}{c}\text { Delivery Cost } \\
\text { (\$/GEG) }\end{array}$ & $\begin{array}{c}\text { Dispensing } \\
\text { Cost }\end{array}$ & $\begin{array}{c}\text { Total } \\
\text { Hydrogen } \\
\text { Cost } \\
\text { (\$/GEG) } \\
\end{array}$ & Comments \\
\hline 2010 & 3.73 & 0.00 & 0.12 & 1.13 & 4.98 & Cryogenic Tanker Delivery \\
\hline 2020 & 2.07 & 0.00 & 1.22 & 0.91 & 4.20 & $\begin{array}{l}\text { Mixed Cryo + Pipeline Delivery } \\
(50 \% \text { each })\end{array}$ \\
\hline 2030 & 1.79 & 0.00 & 0.59 & 0.72 & 3.09 & Pipeline Delivery \\
\hline 2040 & 1.77 & 0.00 & 0.20 & 0.61 & 2.58 & Pipeline Delivery \\
\hline 2050 & 1.75 & 0.00 & 0.18 & 0.44 & 2.37 & Pipeline Delivery \\
\hline
\end{tabular}


Table A.4 Centralized Production of $\mathrm{H}_{2}$ via Electrolysis

Hydrogen Production, Dispensing, and Delivery Cost Estimates, Electrolysis

\begin{tabular}{ccccl}
\hline Year & $\begin{array}{c}\text { Hydrogen } \\
\text { Production Cost, } \\
\text { (\$/GEG) }\end{array}$ & $\begin{array}{c}\text { Dispensing and } \\
\text { Delivery Cost } \\
\text { (\$/GEG) }\end{array}$ & $\begin{array}{c}\text { Total Hydrogen } \\
\text { Cost } \\
\text { (\$/GEG) }\end{array}$ & Comments \\
\hline & & & & \\
2010 & 4.63 & 2.72 & 7.36 & Tube Trailer Delivery \\
2020 & 2.94 & 1.43 & 4.38 & Tube trailer/pipeline mix \\
2030 & 2.78 & 0.97 & 3.75 & Tube trailer/pipeline mix \\
2040 & 2.75 & 0.65 & 3.40 & Tube trailer/pipeline mix \\
2050 & 2.62 & 0.49 & 3.11 & Tube trailer/pipeline mix \\
\hline
\end{tabular}


Table A.5 Distributed Hydrogen Production and Dispensing Using Natural Gas

Distributed Hydrogen Production and Dispensing Cost Estimates, Natural Gas Resource-East South Central Region

\begin{tabular}{cccccc}
\hline Year & $\begin{array}{c}\text { Station Size } \\
\text { (\# of Refills/Day) }\end{array}$ & $\begin{array}{c}\text { Capital Recovery } \\
\text { Cost } \\
\text { (\$/GEG) }\end{array}$ & $\begin{array}{c}\text { Energy Costs } \\
\text { (\$/GEG) }\end{array}$ & $\begin{array}{c}\text { Non-Energy } \\
\text { Operating Costs } \\
\text { (\$/GEG) }\end{array}$ & $\begin{array}{c}\text { Total Hydrogen } \\
\text { Cost } \\
\text { (\$/GEG) }\end{array}$ \\
\hline & & & & & \\
2010 & 79 & 2.26 & 1.25 & 0.75 & 4.27 \\
2020 & 130 & 2.01 & 1.29 & 0.67 & 3.97 \\
2030 & 55 & 2.44 & 1.29 & 0.81 & 4.55 \\
2040 & 121 & 2.05 & 1.28 & 0.68 & 4.01 \\
2050 & 150 & 1.96 & 1.27 & 0.65 & 3.88 \\
\hline
\end{tabular}

Distributed Hydrogen Production and Dispensing Cost Estimates, Natural Gas Resource-West South Central Region

\begin{tabular}{cccccc}
\hline Year & $\begin{array}{c}\text { Station Size } \\
\text { (\# of Refills/Day) }\end{array}$ & $\begin{array}{c}\text { Capital Recovery } \\
\text { Cost } \\
\text { (\$/GEG) }\end{array}$ & $\begin{array}{c}\text { Energy Costs } \\
\text { (\$/GEG) }\end{array}$ & $\begin{array}{c}\text { Non-Energy } \\
\text { Operating Costs } \\
\text { (\$/GEG) }\end{array}$ & $\begin{array}{c}\text { Total Hydrogen } \\
\text { Cost } \\
\text { (\$/GEG) }\end{array}$ \\
\hline 2010 & & & & & \\
2020 & 19 & 2.26 & 1.09 & 0.75 & 4.11 \\
2030 & 55 & 2.15 & 1.14 & 0.72 & 4.00 \\
2040 & 122 & 2.44 & 1.16 & 0.81 & 4.41 \\
2050 & 151 & 2.05 & 1.17 & 0.68 & 3.90 \\
\hline
\end{tabular}

Distributed Hydrogen Production and Dispensing Cost Estimates, Natural Gas Resource-West North Central Region

\begin{tabular}{cccccc}
\hline Year & $\begin{array}{c}\text { Station Size } \\
\text { (\# of Refills/Day) }\end{array}$ & $\begin{array}{c}\text { Capital Recovery } \\
\text { Cost } \\
\text { (\$/GEG) }\end{array}$ & $\begin{array}{c}\text { Energy Costs } \\
\text { (\$/GEG) }\end{array}$ & $\begin{array}{c}\text { Non-Energy } \\
\text { Operating Costs } \\
\text { (\$/GEG) }\end{array}$ & $\begin{array}{c}\text { Total Hydrogen } \\
\text { Cost } \\
\text { (\$/GEG) }\end{array}$ \\
\hline & & & & & \\
2010 & 79 & 2.26 & 1.11 & 0.75 & 4.13 \\
2020 & 72 & 2.32 & 1.15 & 0.77 & 4.24 \\
2030 & 52 & 2.48 & 1.25 & 0.83 & 4.56 \\
2040 & 115 & 2.08 & 1.35 & 0.69 & 4.12 \\
2050 & 142 & 1.99 & 1.46 & 0.66 & 4.11 \\
\hline
\end{tabular}


Table A.5 (Cont.)

Distributed Hydrogen Production and Dispensing Cost Estimates, Natural Gas Resource-New England Region

\begin{tabular}{cccccc}
\hline Year & $\begin{array}{c}\text { Station Size } \\
\text { (\# of Refills/Day) }\end{array}$ & $\begin{array}{c}\text { Capital Recovery } \\
\text { Cost } \\
\text { (\$/GEG) }\end{array}$ & $\begin{array}{c}\text { Energy Costs } \\
\text { (\$/GEG) }\end{array}$ & $\begin{array}{c}\text { Non-Energy } \\
\text { Operating Costs } \\
\text { (\$/GEG) }\end{array}$ & $\begin{array}{c}\text { Total Hydrogen } \\
\text { Cost } \\
\text { (\$/GEG) }\end{array}$ \\
\hline & & & & & \\
2010 & 79 & 2.26 & 1.40 & 0.75 & 4.42 \\
2020 & 89 & 2.19 & 1.44 & 0.73 & 4.37 \\
2030 & 61 & 2.42 & 1.52 & 0.81 & 4.74 \\
2040 & 136 & 1.99 & 1.57 & 0.66 & 4.23 \\
2050 & 169 & 1.90 & 1.64 & 0.63 & 4.17 \\
\hline
\end{tabular}

Distributed Hydrogen Production and Dispensing Cost Estimates, Natural Gas Resource-South Atlantic Region

\begin{tabular}{cccccc}
\hline Year & $\begin{array}{c}\text { Station Size } \\
\text { (\# of Refills/Day) }\end{array}$ & $\begin{array}{c}\text { Capital Recovery } \\
\text { Cost } \\
\text { (\$/GEG) }\end{array}$ & $\begin{array}{c}\text { Non-Energy } \\
\text { Engy Costs } \\
\text { (\$GEG) }\end{array}$ & $\begin{array}{c}\text { Total Hydrogen } \\
\text { Operating Costs } \\
\text { (\$/GEG) }\end{array}$ & $\begin{array}{c}\text { Cost } \\
\text { (\$/GEG) }\end{array}$ \\
\hline & & & & & \\
2010 & 79 & 2.26 & 1.32 & 0.75 & 4.34 \\
2020 & 160 & 1.93 & 1.35 & 0.64 & 3.92 \\
2030 & 58 & 2.41 & 1.35 & 0.80 & 4.56 \\
2040 & 128 & 2.02 & 1.33 & 0.67 & 4.03 \\
2050 & 159 & 1.93 & 1.32 & 0.64 & 3.89 \\
\hline
\end{tabular}

Distributed Hydrogen Production and Dispensing Cost Estimates, Natural Gas Resource-Pacific Region (except Alaska)

\begin{tabular}{cccccc}
\hline Year & $\begin{array}{c}\text { Station Size } \\
\text { (\# of Refills/Day) }\end{array}$ & $\begin{array}{c}\text { Capital Recovery } \\
\text { Cost } \\
\text { (\$/GEG) }\end{array}$ & $\begin{array}{c}\text { Energy Costs } \\
\text { (\$/GEG) }\end{array}$ & $\begin{array}{c}\text { Non-Energy } \\
\text { Operating Costs } \\
\text { (\$/GEG) }\end{array}$ & $\begin{array}{c}\text { Total Hydrogen } \\
\text { Cost } \\
\text { (\$/GEG) }\end{array}$ \\
\hline & & & & & \\
2010 & 79 & 2.26 & 1.32 & 0.75 & 4.33 \\
2020 & 105 & 2.13 & 1.30 & 0.71 & 4.13 \\
2030 & 68 & 2.36 & 1.42 & 0.78 & 4.56 \\
2040 & 151 & 1.96 & 1.54 & 0.65 & 4.15 \\
2050 & 186 & 1.87 & 1.68 & 0.62 & 4.16 \\
\hline
\end{tabular}


Table A.5 (Cont.)

Distributed Hydrogen Production and Dispensing Cost Estimates, Natural Gas Resource-Mountain Region

\begin{tabular}{cccccc}
\hline Year & $\begin{array}{c}\text { Station Size } \\
\text { (\# of Refills/Day) }\end{array}$ & $\begin{array}{c}\text { Capital Recovery } \\
\text { Cost } \\
\text { (\$/GEG) }\end{array}$ & $\begin{array}{c}\text { Energy Costs } \\
\text { (\$/GEG) }\end{array}$ & $\begin{array}{c}\text { Non-Energy } \\
\text { Operating Costs } \\
\text { (\$/GEG) }\end{array}$ & $\begin{array}{c}\text { Total Hydrogen } \\
\text { Cost } \\
\text { (\$/GEG) }\end{array}$ \\
\hline & & & & & \\
2010 & 79 & 2.26 & 1.08 & 0.75 & 4.09 \\
2020 & 52 & 2.48 & 1.12 & 0.83 & 4.42 \\
2030 & 76 & 2.29 & 1.26 & 0.76 & 4.31 \\
2040 & 168 & 1.90 & 1.39 & 0.63 & 3.93 \\
2050 & 208 & 1.81 & 1.55 & 0.60 & 3.96 \\
\hline
\end{tabular}

Distributed Hydrogen Production and Dispensing Cost Estimates, Natural Gas Resource-Middle Atlantic Region

\begin{tabular}{cccccc}
\hline Year & $\begin{array}{c}\text { Station Size } \\
\text { (\# of Refills/Day) }\end{array}$ & $\begin{array}{c}\text { Capital Recovery } \\
\text { Cost } \\
\text { (\$/GEG) }\end{array}$ & $\begin{array}{c}\text { Non-Energy } \\
\text { Engy Costs } \\
\text { (\$GEG) }\end{array}$ & $\begin{array}{c}\text { Total Hydrogen } \\
\text { Operating Costs } \\
\text { (\$/GEG) }\end{array}$ & $\begin{array}{c}\text { Cost } \\
\text { (\$/GEG) }\end{array}$ \\
\hline 2010 & 79 & 2.26 & 1.24 & 0.75 & 4.26 \\
2020 & 115 & 2.08 & 1.30 & 0.69 & 4.07 \\
2030 & 65 & 2.38 & 1.34 & 0.79 & 4.52 \\
2040 & 145 & 1.98 & 1.37 & 0.66 & 4.01 \\
2050 & 179 & 1.87 & 1.41 & 0.62 & 3.90 \\
\hline
\end{tabular}

Distributed Hydrogen Production and Dispensing Cost Estimates, Natural Gas Resource-East North Central Region

\begin{tabular}{cccccc}
\hline Year & $\begin{array}{c}\text { Station Size } \\
\text { (\# of Refills/Day) }\end{array}$ & $\begin{array}{c}\text { Capital Recovery } \\
\text { Cost } \\
\text { (\$/GEG) }\end{array}$ & $\begin{array}{c}\text { Energy Costs } \\
\text { (\$/GEG) }\end{array}$ & $\begin{array}{c}\text { Non-Energy } \\
\text { Operating Costs } \\
\text { (\$/GEG) }\end{array}$ & $\begin{array}{c}\text { Total Hydrogen } \\
\text { Cost } \\
\text { (\$/GEG) }\end{array}$ \\
\hline & & & & & \\
2010 & 79 & 2.26 & 1.13 & 0.75 & 4.15 \\
2020 & 114 & 2.08 & 1.18 & 0.69 & 3.96 \\
2030 & 65 & 2.39 & 1.24 & 0.79 & 4.42 \\
2040 & 143 & 1.98 & 1.29 & 0.66 & 3.93 \\
2050 & 177 & 1.87 & 1.34 & 0.62 & 3.84 \\
\hline
\end{tabular}


Table A.5 (Cont.)

Distributed Hydrogen Production and Dispensing Cost Estimates, Natural Gas Resource-Alaska

\begin{tabular}{lccccc}
\hline Year & $\begin{array}{c}\text { Station Size } \\
\text { (\# of Refills/Day) }\end{array}$ & $\begin{array}{c}\text { Capital Recovery } \\
\text { Cost } \\
\text { (\$/GEG) }\end{array}$ & $\begin{array}{c}\text { Energy Costs } \\
\text { (\$/GEG) }\end{array}$ & $\begin{array}{c}\text { Non-Energy } \\
\text { Operating Costs } \\
\text { (\$/GEG) }\end{array}$ & $\begin{array}{c}\text { Total Hydrogen } \\
\text { Cost } \\
\text { (\$/GEG) }\end{array}$ \\
\hline 2010 & 79 & 2.26 & 1.32 & 0.75 & 4.33 \\
2020 & 12 & 3.44 & 1.30 & 1.15 & 5.89 \\
2030 & 70 & 2.34 & 1.42 & 0.78 & 4.54 \\
2040 & 155 & 1.94 & 1.54 & 0.65 & 4.13 \\
2050 & 192 & 1.85 & 1.68 & 0.62 & 4.15 \\
\hline
\end{tabular}


Table A.6 Distributed Hydrogen Production and Dispensing Using Electrolysis — Detailed Results for Selected Regions

Distributed Hydrogen Production and Dispensing Cost Estimates, Commercial Electricity South Atlantic

\begin{tabular}{ccccccc}
\hline Year & $\begin{array}{c}\text { Station Size } \\
\text { \# of Refills/Day) }\end{array}$ & $\begin{array}{c}\text { Capital Recovery } \\
\text { Cost } \\
\text { (\$/GEG) }\end{array}$ & $\begin{array}{c}\text { Energy Costs } \\
\text { (\$/GEG) }\end{array}$ & $\begin{array}{c}\text { Non-Energy } \\
\text { Operating Costs } \\
\text { (\$/GEG) }\end{array}$ & $\begin{array}{c}\text { Taxes \& Retail } \\
\text { Markup } \\
\text { (\$/GEG) }\end{array}$ & $\begin{array}{c}\text { Total Hydrogen } \\
\text { Cost } \\
\text { (\$/GEG) }\end{array}$ \\
\hline & & & & & & \\
2020 & 160 & 4.35 & 3.52 & 1.45 & 0.00 & 9.32 \\
2030 & 58 & 4.58 & 3.43 & 1.53 & 0.00 & 9.54 \\
2040 & 128 & 3.99 & 3.35 & 1.33 & 0.00 & 8.68 \\
2050 & 159 & 3.90 & 3.48 & 1.30 & 0.00 & 8.68 \\
\hline
\end{tabular}

Distributed Hydrogen Production and Dispensing Cost Estimates, Commercial Electricity Contiguous Pacific

\begin{tabular}{ccccccc}
\hline & Station Size & $\begin{array}{c}\text { Capital Recovery } \\
\text { Cost } \\
\text { Year }\end{array}$ & $\begin{array}{c}\text { Energy Costs } \\
\text { (\# of Refills/Day) }\end{array}$ & $\begin{array}{c}\text { Non-Energy } \\
\text { Operating Costs } \\
\text { (\$/GEG) }\end{array}$ & $\begin{array}{c}\text { Taxes \& Retail } \\
\text { Markup } \\
\text { (\$/GEG) }\end{array}$ & $\begin{array}{c}\text { Total Hydrogen } \\
\text { Cost } \\
\text { (\$/GEG) }\end{array}$ \\
\hline & & & & & & \\
2020 & 105 & 5.51 & 4.18 & 1.84 & 0.00 & 11.53 \\
2030 & 68 & 5.47 & 4.15 & 1.82 & 0.00 & 11.45 \\
2040 & 151 & 4.75 & 4.14 & 1.58 & 0.00 & 10.47 \\
2050 & 186 & 4.64 & 4.38 & 1.55 & 0.00 & 10.56 \\
\hline
\end{tabular}

Distributed Hydrogen Production and Dispensing Cost Estimates, Commercial Electricity Mountain

\begin{tabular}{ccccccc}
\hline Year & $\begin{array}{c}\text { Station Size } \\
\text { (\# of Refills/Day) }\end{array}$ & $\begin{array}{c}\text { Capital Recovery } \\
\text { Cost } \\
\text { (\$/GEG) }\end{array}$ & $\begin{array}{c}\text { Energy Costs } \\
\text { (\$/GEG) }\end{array}$ & $\begin{array}{c}\text { Non-Energy } \\
\text { Operating Costs } \\
\text { (\$/GEG) }\end{array}$ & $\begin{array}{c}\text { Taxes \& Retail } \\
\text { Markup } \\
\text { (\$/GEG) }\end{array}$ & $\begin{array}{c}\text { Total Hydrogen } \\
\text { Cost } \\
\text { (\$/GEG) }\end{array}$ \\
\hline 2020 & 52 & & & & & \\
2030 & 76 & 5.22 & 3.40 & 1.74 & 0.00 & 10.37 \\
2040 & 168 & 4.75 & 3.29 & 1.58 & 0.00 & 9.63 \\
2050 & 208 & 4.12 & 3.20 & 1.37 & 0.00 & 8.70 \\
\hline
\end{tabular}


Table A.6 (Cont.)

Distributed Hydrogen Production and Dispensing Cost Estimates, Commercial Electricity West North Central

\begin{tabular}{ccccccc}
\hline Year & $\begin{array}{c}\text { Station Size } \\
\text { (\# of Refills/Day) }\end{array}$ & $\begin{array}{c}\text { Capital Recovery } \\
\text { Cost } \\
\text { (\$/GEG) }\end{array}$ & $\begin{array}{c}\text { Energy Costs } \\
\text { (\$/GEG) }\end{array}$ & $\begin{array}{c}\text { Non-Energy } \\
\text { Operating Costs } \\
\text { (\$/GEG) }\end{array}$ & $\begin{array}{c}\text { Taxes \& Retail } \\
\text { Markup } \\
\text { (\$/GEG) }\end{array}$ & $\begin{array}{c}\text { Total Hydrogen } \\
\text { Cost } \\
\text { (\$/GEG) }\end{array}$ \\
\hline & & & & & & \\
2020 & 72 & 5.36 & 3.02 & 1.79 & 0.00 & 10.17 \\
2030 & 52 & 5.24 & 2.96 & 1.74 & 0.00 & 9.94 \\
2040 & 115 & 4.56 & 2.92 & 1.52 & 0.00 & 9.00 \\
2050 & 142 & 4.46 & 3.04 & 1.49 & 0.00 & 8.99 \\
\hline
\end{tabular}

Distributed Hydrogen Production and Dispensing Cost Estimates, Commercial Electricity Middle Atlantic

\begin{tabular}{ccccccc}
\hline & $\begin{array}{c}\text { Station Size } \\
\text { \# of Refills/Day) }\end{array}$ & $\begin{array}{c}\text { Capital Recovery } \\
\text { Cost } \\
\text { (\$/GEG) }\end{array}$ & $\begin{array}{c}\text { Energy Costs } \\
\text { (\$/GEG) }\end{array}$ & $\begin{array}{c}\text { Non-Energy } \\
\text { Operating Costs } \\
\text { (\$/GEG) }\end{array}$ & $\begin{array}{c}\text { Taxes \& Retail } \\
\text { Markup } \\
\text { (\$/GEG) }\end{array}$ & $\begin{array}{c}\text { Total Hydrogen } \\
\text { Cost } \\
\text { (\$/GEG) }\end{array}$ \\
\hline & & & & & & \\
2020 & 115 & 5.54 & 4.36 & 1.85 & 0.00 & 11.75 \\
2030 & 65 & 5.59 & 3.87 & 1.86 & 0.00 & 11.32 \\
2040 & 145 & 4.85 & 3.44 & 1.61 & 0.00 & 9.91 \\
2050 & 179 & 4.72 & 3.25 & 1.57 & 0.00 & 9.54 \\
\hline
\end{tabular}


Table A.7 Distributed Hydrogen Production and Dispensing Using Electrolysis - Summary

Results for Selected Regions

Distributed Hydrogen Production and Dispensing Cost Estimates, Commercial Electricity

\begin{tabular}{lcc}
\hline \multicolumn{1}{c}{ Region } & Year & $\begin{array}{c}\text { Total Hydrogen Cost } \\
\text { (\$/GEG) }\end{array}$ \\
\hline New England & & \\
& 2010 & 15.27 \\
& 2020 & 14.13 \\
& 2030 & 13.80 \\
& 2040 & 12.44 \\
& 2050 & 12.35 \\
& & \\
East North Central & & \\
& 2010 & 9.62 \\
& 2020 & 8.90 \\
& 2030 & 8.69 \\
& 2040 & 7.83 \\
& 2050 & 7.78 \\
& & \\
& & \\
& 2010 & 10.23 \\
& 2020 & 9.47 \\
& 2030 & 9.24 \\
& 2040 & 8.33 \\
& 2050 & 8.28 \\
& & \\
& & \\
& 2010 & 12.37 \\
& 2020 & 11.45 \\
& 2030 & 11.18 \\
& & 10.07 \\
& & 10.01 \\
\hline
\end{tabular}




\section{APPENDIX B: ALTERNATIVE ESTIMATES OF THE COST OF DISTRIBUTED PRODUCTION OF HYDROGEN FROM ELECTROLYSIS}

Table B.1 SFA and DTI Estimates of the Cost of Distributed Hydrogen Production from Electrolysis

\begin{tabular}{|c|c|c|c|}
\hline \multirow[b]{2}{*}{ Item } & \multicolumn{2}{|c|}{ Source } & \multirow[b]{2}{*}{ Comments } \\
\hline & SFA & DTI & \\
\hline \multicolumn{4}{|l|}{ Performance Characteristics: } \\
\hline Station Design $\mathrm{H}_{2}$ Production Rate $(\mathrm{kg} / \mathrm{d})$ & 920 & 920 & SFA rate adjusted to $=$ DTI assumptions \\
\hline Electrolyzer Direct Cost $(\$ / \mathrm{kWe})$ & $\$ 2,017$ & $\$ 300$ & \\
\hline $\begin{array}{l}\text { Overall Indirect Capital Cost Factor } \\
\text { (percent of direct CC) }\end{array}$ & $63.9 \%$ & $0 \%$ & \\
\hline Electrolyzer Efficiency & $75 \%$ & $89 \%$ & DTI value back-calculated. \\
\hline Electrolyzer Capacity Factor & $70 \%$ & $69 \%$ & \\
\hline Plant Lifetime (yrs) & $\mathrm{n} / \mathrm{a}$ & 10 & \\
\hline Capital Charge Factor & $18.0 \%$ & $16.8 \%$ & DTI value calculated. \\
\hline Discount Rate & $\mathrm{n} / \mathrm{a}$ & $10.8 \%$ & DTI number calculated. \\
\hline Fixed O\&M Cost ( $\%$ of capital cost) & $5.0 \%$ & $2.50 \%$ & \\
\hline Labor Cost $(\$ / \mathrm{kg})$ & $\mathrm{n} / \mathrm{a}$ & $\$ 0.76$ & DTI number calculated. \\
\hline Non-Fuel O\&M Costs ( $\%$ of capital cost) & $1 \%$ & $\mathrm{n} / \mathrm{a}$ & \\
\hline Corporate Overhead (\% of revenue) & $\mathrm{n} / \mathrm{a}$ & $15 \%$ & \\
\hline \multicolumn{4}{|l|}{ Capital Costs } \\
\hline Electrolyzer Direct Capital Cost & $\$ 4,058,186$ & $\$ 510,000$ & $\begin{array}{l}\text { Both models with } 920 \mathrm{~kW} / \text { day } \mathrm{H}_{2} \\
\text { production capacity (= } 155 \text { refuelings/day) }\end{array}$ \\
\hline Compressor Direct Capital Cost & $\$ 273,625$ & $\mathrm{n} / \mathrm{a}$ & \\
\hline $\mathrm{H}_{2}$ Storage Direct Capital Cost & $\$ 209,533$ & $\mathrm{n} / \mathrm{a}$ & \\
\hline $\mathrm{H}_{2}$ Dispensing Direct Capital Cost & $\$ 60,000$ & $\mathrm{n} / \mathrm{a}$ & \\
\hline Total-Compressor + Storage + Dispensing & $\$ 543,158$ & $\$ 470,000$ & $\begin{array}{l}\text { All compressor, storage \& dispensing costs } \\
\text { combined in DTI report }\end{array}$ \\
\hline \multicolumn{4}{|l|}{ Indirect Cost Factors (applied to all capital costs) } \\
\hline General Facilities ( $\%$ of Direct Cost): & $20 \%$ & $\mathrm{n} / \mathrm{a}$ & \\
\hline Engineering & $10 \%$ & $\mathrm{n} / \mathrm{a}$ & \\
\hline Contingencies & $10 \%$ & $\mathrm{n} / \mathrm{a}$ & \\
\hline Working Capital & $9 \%$ & $\mathrm{n} / \mathrm{a}$ & \\
\hline Regional Factor & $10 \%$ & $\mathrm{n} / \mathrm{a}$ & \\
\hline Overall Indirect Factor & $49 \%$ & & \\
\hline Regional Cost Factor (on all costs) & $14.9 \%$ & $\mathrm{n} / \mathrm{a}$ & \\
\hline Overall Indirect Factor & $63.9 \%$ & $\mathrm{n} / \mathrm{a}$ & \\
\hline Total Electrolyzer Installed Cost & $\$ 6,651,367$ & $\$ 510,000$ & \\
\hline Total Compressor, Storage, Dispensing Cost & $\$ 890,236$ & $\$ 470,000$ & \\
\hline $\begin{array}{l}\text { Total Electrolysis } \\
\text { System Construction/Commissioning Cost }\end{array}$ & $\$ 7,541,603$ & $\$ 980,000$ & \\
\hline
\end{tabular}




\section{APPENDIX C: KEY ASSUMPTIONS IN REGIONAL $\mathrm{H}_{2}$ MODEL 1.0}

Table C.1 presents key assumptions underlying the current version of the Regional $\mathrm{H}_{2}$ Model. Sources are provided. Where appropriate, estimates of the level of difficulty of changing the assumptions used in the model are also provided. (In some cases, where we think it is most needed, we provide an explanation for the particular estimate.) The level-of-difficulty categories, as shown in the table, are as follows:

- A: Easy to change;

- B: Moderately easy to change;

- C: Difficult, but not impossible, to change; and

- D: Not possible to change.

See the full report for a complete discussion of the assumptions.

Table C.1 Key Assumptions in Regional $\mathrm{H}_{2}$ Model 1.0

\begin{tabular}{|c|c|c|c|}
\hline $\begin{array}{l}\text { Topic and Topic } \\
\text { Number }\end{array}$ & Key Assumptions & Source & $\begin{array}{l}\text { Level of Difficulty in } \\
\text { Changing Assumption }\end{array}$ \\
\hline \multicolumn{4}{|l|}{$\begin{array}{l}\text { H }_{2} \text { DEMAND (D) } \\
\text { Total U.S. }\end{array}$} \\
\hline D1 & $\begin{array}{l}\text { Total FCV penetration based on the } \\
\text { following assumptions: } \\
\text { 1. FCV sales start in } 2015 \text { (except for } \\
\text { limited demonstrations). } \\
\text { 2. FCV sales reach } 50 \% \text { of light } \\
\text { vehicles (LVs) (cars and light trucks } \\
\text { [LTs]) by } 2035 \text { and plateau there } \\
\text { through } 2050 \text {. }\end{array}$ & $\begin{array}{l}\text { One scenario of a joint } \\
\text { DOE/NRCan study } \\
\text { (Patterson et al. 2003) }\end{array}$ & $\begin{array}{l}\text { A (assumes use of } \\
\text { VISION model } \\
\text { developed for } \\
\text { DOE/EERE to generate } \\
\text { another scenario [Singh, } \\
\text { Vyas, and Steiner 2003]) }\end{array}$ \\
\hline D2 & $\begin{array}{l}\text { New FCV fuel economy in gasoline } \\
\text { gallons equivalent (GGE) is as follows: } \\
\text { 1. For cars: Starts at } 55.8 \text { MPG (2015) } \\
\text { and reaches } 80.3 \text { MPG (2050). } \\
\text { 2. For LTs: Starts at } 41.5 \text { MPG (2015) } \\
\text { and reaches 59.7 MPG (2050). }\end{array}$ & $\begin{array}{l}\text { One scenario of a joint } \\
\text { DOE/NRCan study } \\
\text { (Patterson et al. 2003) }\end{array}$ & $\begin{array}{l}\text { A (assumes use of } \\
\text { VISION model } \\
\text { developed for } \\
\text { DOE/EERE to generate } \\
\text { another scenario [Singh, } \\
\text { Vyas, and Steiner 2003]) }\end{array}$ \\
\hline D3 & $\begin{array}{l}\text { Total light-vehicle annual sales, stock } \\
\text { vintaging, on-road fuel economy } \\
\text { degradation factor, annual miles of } \\
\text { travel, and other parameters are those } \\
\text { estimated in the VISION model. }\end{array}$ & $\begin{array}{l}\text { VISION model } \\
\text { developed for } \\
\text { DOE/EERE (Singh, } \\
\text { Vyas, and Steiner 2003) }\end{array}$ & $\begin{array}{l}\text { C (not easy to change the } \\
\text { VISION model itself) }\end{array}$ \\
\hline
\end{tabular}


Table C.1 (Cont.)

\begin{tabular}{|c|c|c|c|}
\hline $\begin{array}{l}\text { Topic and Topic } \\
\text { Number }\end{array}$ & Key Assumptions & Source & $\begin{array}{c}\text { Level of Difficulty in } \\
\text { Changing Assumption }\end{array}$ \\
\hline \multicolumn{4}{|c|}{ By Census Region (with Alaska and Hawaii disaggregated from the Pacific region) } \\
\hline D4 & $\begin{array}{l}\text { Total } \mathrm{H}_{2} \text { demand allocated according to } \\
\text { year } 2000 \text { motor gasoline use for } \\
\text { transportation by region. }\end{array}$ & EIA $^{\mathrm{b}}$ & $\begin{array}{l}\text { B (could input } \\
\text { alternative regional } \\
\text { demand estimates) }\end{array}$ \\
\hline \multicolumn{4}{|c|}{ Within Census Region } \\
\hline D5 & $\begin{array}{l}\text { Within each U.S. census region, total } \\
\mathrm{H}_{2} \text { demand allocated to metropolitan } \\
\text { (metro) areas vs. non-metro areas } \\
\text { according to year } 2002 \text { LV VMT } \\
\text { estimates for those areas. }\end{array}$ & $\mathrm{EPA}^{\mathrm{c}}$ & $\begin{array}{l}\text { B (could input } \\
\text { alternative metro vs. } \\
\text { non-metro demand } \\
\text { estimates) }\end{array}$ \\
\hline \multicolumn{4}{|l|}{ Over time } \\
\hline D6 & $\begin{array}{l}\text { FCV market penetration occurs at the } \\
\text { same rate in all U.S. Census regions. }\end{array}$ & $\begin{array}{l}\text { Assumption made by } \\
\text { model developers }\end{array}$ & $\begin{array}{l}\mathrm{C} / \mathrm{D} \text { (would require } \\
\text { significant changes in } \\
\text { the model) }\end{array}$ \\
\hline \multirow[t]{4}{*}{ D7 } & $\begin{array}{l}\text { FCV travel and thus fuel use occurs } \\
\text { first in metro areas and gradually } \\
\text { expands to non-metro areas (see } \\
\text { Table 2.4): }\end{array}$ & $\begin{array}{l}\text { Assumption made by } \\
\text { model developers }\end{array}$ & \\
\hline & $\begin{array}{l}\text { 1. By } 2020 \text {, no non-metro FCV travel } \\
\text { except along non-metro interstates } \\
\text { (by region). }\end{array}$ & $\begin{array}{l}\text { Assumption made by } \\
\text { model developers }\end{array}$ & $\begin{array}{l}\text { C (would require } \\
\text { changes to model) }\end{array}$ \\
\hline & $\begin{array}{l}\text { 2. By } 2030, \mathrm{FCVs} \text { meet } 60 \% \text { of the } \\
\text { non-metro travel requirements of the } \\
\text { average LV (by region). }\end{array}$ & $\begin{array}{l}\text { Assumption made by } \\
\text { model developers }\end{array}$ & A \\
\hline & $\begin{array}{l}\text { 3. By } 2040, \text { FCVs meet all of the non- } \\
\text { metro travel requirements of the } \\
\text { average LV (by region). }\end{array}$ & $\begin{array}{l}\text { Assumption made by } \\
\text { model developers }\end{array}$ & A \\
\hline \multicolumn{4}{|c|}{$\mathrm{H}_{2}$ PRODUCTION (P) } \\
\hline P1 & $\begin{array}{l}\text { Each Census region will produce } \\
\text { sufficient } \mathrm{H}_{2} \text { to meet the region's } \\
\text { demand in all years. }\end{array}$ & $\begin{array}{l}\text { Assumption made by } \\
\text { model developers }\end{array}$ & $\mathrm{D}$ \\
\hline
\end{tabular}


Table C.1 (Cont.)

\begin{tabular}{|c|c|c|c|}
\hline $\begin{array}{l}\text { Topic and Topic } \\
\text { Number }\end{array}$ & Key Assumptions & Source & $\begin{array}{l}\text { Level of Difficulty in } \\
\text { Changing Assumption }\end{array}$ \\
\hline \multirow[t]{3}{*}{$\mathrm{P} 2$} & $\begin{array}{l}\text { Relative resource fuel availability in a } \\
\text { region determines the likelihood of } \\
\text { each resource being used to produce } \mathrm{H}_{2} \\
\text { in that region: }\end{array}$ & $\begin{array}{l}\text { Assumption made by } \\
\text { model developers }\end{array}$ & \\
\hline & $\begin{array}{l}\text { 1. Each region's natural gas, coal, } \\
\text { biomass, wind }{ }^{\mathrm{d}} \text {, and solar resource } \\
\text { fuels individually receive an } \\
\text { "availability ranking" according to } \\
\text { existing characterizations of the } \\
\text { availability of the resources. The } \\
\text { biomass, wind, and solar rankings } \\
\text { are combined into one renewables } \\
\text { ranking. (See Table 3.1.) }\end{array}$ & $\begin{array}{l}\text { EIA, } \mathrm{ORNL}^{\mathrm{e}} \text {, and } \\
\text { NREL }^{\mathrm{f}}, \text { data/estimates } \\
(\text { EIA 2001, 2002, 2003) }\end{array}$ & $\begin{array}{l}\mathrm{C} \text { (would require } \\
\text { changes to model) }\end{array}$ \\
\hline & $\begin{array}{l}\text { 2. Each region's nuclear "availability } \\
\text { ranking" is based on whether any } \\
\text { nuclear plants exist in the region or } \\
\text { not. (See Table 3.1.) }\end{array}$ & $\mathrm{EIA}^{\mathrm{g}}$ & $\mathrm{B}$ \\
\hline \multicolumn{4}{|c|}{ Centralized versus distributed production } \\
\hline $\mathrm{P} 3$ & $\begin{array}{l}\text { Distributed production is used to serve } \\
100 \% \text { of a FCV's non-metro interstate } \\
\text { travel in } 2020 \text { and } 75 \% \text { of a FCV's } \\
\text { non-metro travel by } 2030 \text { and beyond } \\
\text { (by region). Centralized production } \\
\text { provides all other } \mathrm{H}_{2} .\end{array}$ & $\begin{array}{l}\text { Assumption made by } \\
\text { model developers }\end{array}$ & A \\
\hline \multicolumn{4}{|c|}{ Allocation of regional resource fuels for centralized production } \\
\hline $\mathrm{P} 4$ & $\begin{array}{l}\text { Natural gas use is phased out by } 2050 \text {, } \\
\text { but has longest use in more highly } \\
\text { ranked regions. (See Table 3.5.) }\end{array}$ & $\begin{array}{l}\text { Assumption made by } \\
\text { model developers }\end{array}$ & $\mathrm{B}$ \\
\hline P5 & $\begin{array}{l}\text { Up to } 5 \% \text { of current electricity sales in } \\
\text { a region can be used to produce } \mathrm{H}_{2} \\
\text { ("centralized electrolysis using general } \\
\text { utility resource fuel mix") and that } \\
\text { amount continues through } 2050 \text {. (See } \\
\text { Table 3.2.) }\end{array}$ & $\begin{array}{l}\text { Assumption made by } \\
\text { model developers }\end{array}$ & B \\
\hline P6 & $\begin{array}{l}\text { No more than } 30 \% \text { of a region's } \mathrm{H}_{2} \\
\text { demand in any year can be met by } \\
\text { "centralized electrolysis using general } \\
\text { utility resource fuel mix," up to the } 5 \% \\
\text { limit in P5. }\end{array}$ & $\begin{array}{l}\text { Assumption made by } \\
\text { model developers }\end{array}$ & $\mathrm{B}$ \\
\hline
\end{tabular}


Table C.1 (Cont.)

\begin{tabular}{|c|c|c|c|}
\hline $\begin{array}{c}\text { Topic and Topic } \\
\text { Number }\end{array}$ & Key Assumptions & Source & $\begin{array}{l}\text { Level of Difficulty in } \\
\text { Changing Assumption }\end{array}$ \\
\hline P7 & $\begin{array}{l}\text { Thermochemical water splitting using } \\
\text { advanced, high-temperature nuclear } \\
\text { reactors ("nuclear") will not be in use } \\
\text { until } 2030 \text {. It will meet } 1 \% \text { of the } \mathrm{H}_{2} \\
\text { demand in } 2030,8 \% \text { in } 2040 \text {, and } 20 \% \\
\text { in } 2050 \text { in regions that have nuclear } \\
\text { power and that have a high availability } \\
\text { ranking for either coal or renewables. If } \\
\text { a region has nuclear power, but is not } \\
\text { ranked highly for coal or renewables, it } \\
\text { may use } 25 \% \text { more nuclear power than } \\
\text { average. In regions with no nuclear } \\
\text { plants today, it will not be used. }\end{array}$ & $\begin{array}{l}\text { Assumption made by } \\
\text { model developers }\end{array}$ & $\mathrm{C}$ \\
\hline P8 & $\begin{array}{l}\text { Once the production of } \mathrm{H}_{2} \text { from natural } \\
\text { gas, centralized electrolysis using } \\
\text { general utility resource fuel mix, and } \\
\text { nuclear is estimated for each region, } \\
\text { coal and renewables split the } \\
\text { remainder. The split is based on the } \\
\text { relative "availability rankings" of these } \\
\text { two fuels in each region. (See } \\
\text { Table 3.6.) }\end{array}$ & $\begin{array}{l}\text { Assumption made by } \\
\text { model developers }\end{array}$ & B \\
\hline P9 & $\begin{array}{l}\text { The renewables are split according to } \\
\text { EIA's projected use of these resources } \\
\text { for electricity generation and end-use } \\
\text { sector energy in } 2025 \text {. The same split is } \\
\text { held throughout the analysis period. } \\
\text { (See Table 3.7.) }\end{array}$ & EIA (2003) & B \\
\hline \multicolumn{4}{|c|}{ Allocation of regional resource fuels used for distributed production } \\
\hline P10 & $\begin{array}{l}\text { Both SMR and electrolysis are used for } \\
\text { distributed production. }\end{array}$ & $\begin{array}{l}\text { Assumption made by } \\
\text { model developers }\end{array}$ & $\mathrm{C}$ \\
\hline P11 & $\begin{array}{l}\text { Because SMR is less expensive than } \\
\text { electrolysis, SMR will initially be the } \\
\text { predominant method of distributed } \\
\text { production. }\end{array}$ & $\begin{array}{l}\text { Assumption made by } \\
\text { model developers }\end{array}$ & A \\
\hline $\mathrm{P} 12$ & $\begin{array}{l}\text { No natural gas will be used for } \\
\text { distributed } \mathrm{H}_{2} \text { production by } 2050 \text { in } \\
\text { any region. }\end{array}$ & $\begin{array}{l}\text { Assumption made by } \\
\text { model developers }\end{array}$ & A \\
\hline
\end{tabular}


Table C.1 (Cont.)

\begin{tabular}{|c|c|c|c|}
\hline $\begin{array}{l}\text { Topic and Topic } \\
\text { Number }\end{array}$ & Key Assumptions & Source & $\begin{array}{l}\text { Level of Difficulty in } \\
\text { Changing Assumption }\end{array}$ \\
\hline P13 & $\begin{array}{l}\text { Use of natural gas for distributed } \\
\text { production will phase out in different } \\
\text { regions at various rates, depending on } \\
\text { the region's natural gas "ranking." (See } \\
\text { Table 3.4.) }\end{array}$ & $\begin{array}{l}\text { Assumption made by } \\
\text { model developers }\end{array}$ & $\mathrm{B}$ \\
\hline \multicolumn{4}{|l|}{$\mathrm{H}_{2} \operatorname{COSTS}(\mathrm{C})$} \\
\hline \multicolumn{4}{|c|}{ Centralized production without consideration of regional differences } \\
\hline $\mathrm{C} 1$ & $\begin{array}{l}\text { Used methodology developed by SFA } \\
\text { Pacific, Inc. (SFA), and assumed } \\
\text { technological improvements over time } \\
\text { for SMR, electrolysis, coal, and } \\
\text { biomass. }\end{array}$ & $\begin{array}{l}\text { SFA Pacific, Inc. } \\
(2002)\end{array}$ & $\mathrm{C}$ \\
\hline $\mathrm{C} 2$ & $\begin{array}{l}\text { For wind, solar, and nuclear production } \\
\text { of } \mathrm{H}_{2} \text {, costs are based on relationships } \\
\text { of these technologies to other } \\
\text { technologies. }\end{array}$ & $\begin{array}{l}\text { Assumption made by } \\
\text { model developers }\end{array}$ & $\mathrm{C}$ \\
\hline $\mathrm{C} 3$ & $\begin{array}{l}\text { Assumed carbon sequestration added } \\
20 \% \text { to cost of producing } \mathrm{H}_{2} \text { from coal. }\end{array}$ & $\begin{array}{l}\text { Assumption made by } \\
\text { model developers }\end{array}$ & A \\
\hline \multicolumn{4}{|c|}{ Regional differences in centralized production } \\
\hline $\mathrm{C} 4$ & $\begin{array}{l}\text { Use EIA's regional energy cost } \\
\text { projections for electricity, coal, and } \\
\text { natural gas and extrapolate to } 2050 .\end{array}$ & EIA (2003) & $\begin{array}{l}\text { B (could input } \\
\text { alternative estimates) }\end{array}$ \\
\hline $\mathrm{C} 5$ & $\begin{array}{l}\text { Regional biomass costs derived from } \\
\text { state-level biomass supply curves } \\
\text { provided by ORNL. }\end{array}$ & $\mathrm{ORNL}^{\mathrm{h}}$ & $\mathrm{C}$ \\
\hline \multicolumn{4}{|c|}{ Delivery costs associated with centralized production } \\
\hline C6 & $\begin{array}{l}\text { For delivery of all } \mathrm{H}_{2} \text { centrally } \\
\text { produced (except that produced from } \\
\text { natural gas), assumed that it would first } \\
\text { be delivered by cryogenic tanker and } \\
\text { then pipeline }(100 \% \text { by tanker in } 2010 \text {, } \\
50 / 50 \text { in } 2020 \text {, and } 100 \% \text { pipeline by } \\
2030) \text {. }\end{array}$ & $\begin{array}{l}\text { Assumption made by } \\
\text { model developers }\end{array}$ & $\mathrm{C}$ \\
\hline
\end{tabular}


Table C.1 (Cont.)

\begin{tabular}{|c|c|c|c|}
\hline $\begin{array}{c}\text { Topic and Topic } \\
\text { Number }\end{array}$ & Key Assumptions & Source & $\begin{array}{l}\text { Level of Difficulty in } \\
\text { Changing Assumption }\end{array}$ \\
\hline $\mathrm{C} 7$ & $\begin{array}{l}\text { For delivery of } \mathrm{H}_{2} \text { centrally produced } \\
\text { from natural gas, assumed that it would } \\
\text { only be delivered by cryogenic tanker. } \\
\text { Because of the phase-out of } \mathrm{H}_{2} \\
\text { production from natural gas in general, } \\
\mathrm{H}_{2} \text { pipelines would not be built from } \\
\text { these facilities. }\end{array}$ & $\begin{array}{l}\text { Assumption made by } \\
\text { model developers }\end{array}$ & $\mathrm{C}$ \\
\hline $\mathrm{C} 8$ & $\begin{array}{l}\text { National average } \mathrm{H}_{2} \text { delivery costs } \\
\text { using cryogenic tankers derived from } \\
\text { SFA. No cost reductions over time. }\end{array}$ & $\begin{array}{l}\text { SFA Pacific, Inc. } \\
(2002)\end{array}$ & $\mathrm{C}$ \\
\hline C9 & $\begin{array}{l}\text { National average } \mathrm{H}_{2} \text { delivery costs } \\
\text { using pipeline derived from SFA, but } \\
\text { extensively modified to reflect cost } \\
\text { reductions over time. Modifications } \\
\text { assume amortization of older pipeline } \\
\text { capital costs, conversions of existing } \\
\text { natural gas pipelines and reduction in } \\
\text { average shipment transport distances. }\end{array}$ & $\begin{array}{l}\text { SFA Pacific, Inc. } \\
(2002)\end{array}$ & $\mathrm{C}$ \\
\hline \multicolumn{4}{|c|}{ Regional differences in delivery costs associated with centralized production } \\
\hline $\mathrm{C} 10$ & $\begin{array}{l}\text { Used regional differences in existing } \\
\text { pipeline construction costs, existing } \\
\text { pipeline operating (electricity) costs, } \\
\text { and estimated relative average pipeline } \\
\text { lengths from centralized production } \\
\text { facilities to metro areas to vary regional } \\
\text { pipeline delivery costs. Relative } \\
\text { average pipeline lengths based on \# of } \\
\text { metro areas that have to be served in a } \\
\text { region per } 10,000 \mathrm{mi}^{2} \text {. }\end{array}$ & $\begin{array}{l}\text { R.S. Means } \\
\text { Construction Cost } \\
\text { Estimating Guide } \\
(2002)\end{array}$ & $\mathrm{C}$ \\
\hline $\mathrm{C} 11$ & $\begin{array}{l}\text { Used estimated relative average truck } \\
\text { distances from centralized production } \\
\text { facilities to metro areas to vary regional } \\
\text { truck delivery costs. Relative average } \\
\text { distances based on number of metro } \\
\text { areas that have to be served in a region } \\
\text { per } 10,000 \mathrm{mi}^{2} \text {. }\end{array}$ & $\begin{array}{l}\text { Assumption made by } \\
\text { model developers }\end{array}$ & $\mathrm{C}$ \\
\hline \multicolumn{4}{|c|}{ Dispensing costs associated with centralized production } \\
\hline $\mathrm{C} 12$ & $\begin{array}{l}\text { Used costs estimates developed by } \\
\text { SFA. Assumed cost reductions over } \\
\text { time. }\end{array}$ & $\begin{array}{l}\text { SFA Pacific, Inc. } \\
(2002)\end{array}$ & B \\
\hline
\end{tabular}


Table C.1 (Cont.)

Topic and Topic
Number

Key Assumptions

Level of Difficulty in

Changing Assumption ${ }^{\mathrm{a}}$

Regional differences in dispensing costs associated with centralized production

C13 Assumed no regional differences. Assumption made by

model developers

\section{Distributed production costs without consideration of regional differences}

C14

Used costs estimates developed by

SFA, but modified reformer and

SFA Pacific, Inc.

electrolyzer efficiency improvements

over time. Costs vary by station size.

\section{Regional differences in distributed production costs}

C15

Because cost depends on volume, particularly for stations using SMR, need to estimate average station size (volume) by region. To do so:

1. Assume that eventually there will be the same number of $\mathrm{H}_{2}$ stations in non-metro areas of the United States as there are gasoline stations now in order to provide adequate geographic coverage. (No need to estimate volumes in metro areas because we assume that for a scenario of substantial $\mathrm{H}_{2}$ demand [such as the one analyzed here], distributed production is only used in non-metro areas.)

2. Use Economic Census data to determine the number of gasoline stations in non-metro areas of the United States.

3. Given the number of $\mathrm{H}_{2}$ stations thus estimated, estimate average station volume by region over time by dividing the regional distributed production estimates developed in P3 by these station numbers.

C16

Use EIA's regional energy cost projections for natural gas and Assumption made by model developers

C

U.S. Census Bureau (2000)

Assumption made by

C model developers

C

C

C electricity and extrapolate to 2050 .
EIA (2003)
B (could input alternative estimates)

a The levels of difficulty are as follows: A: Easy to change; B: Moderately easy to change; C: Difficult, but not impossible, to change; D: Not possible to change.

b Energy Information Administration, "Motor Gasoline Consumption, Price and Expenditure Estimates, 2000," available at http://www.eia.doe.gov/emeu/states/sep_fuel/html/fuel_mg.html\#footnotes, accessed Oct. 2003. 
Table C.1 (Cont.)

c Spreadsheets provided by John Koupal, U.S. Environmental Protection Agency (EPA), August 2004. Also see E.H. Pechan \& Associates, Springfield, VA, 2004, "Documentation for the Onroad National Emissions Inventory (NEI) for Base Years 1970-2002,” Jan.

${ }^{\mathrm{d}} \mathrm{http} / /$ www.eere.energy.gov/windpoweringamerica/images/windmaps/wherewind800.jpg, wind resource estimates, accessed Oct. 2003.

e http://bioenergy.ornl.gov/resourcedata/index.html, Biomass Feedstock Availability in the United States: 1999 State Level Analysis, accessed Oct. 2003.

${ }^{\mathrm{f}} \mathrm{http}: / /$ maps.nrel.gov/annualdir.html, solar resource estimates, accessed Oct. 2003.

g http://www.eia.doe.gov/emeu/states/sep_sum/html/sum_btu_1.html, Energy Consumption Estimates by Source and End-Use Sector, 2000, accessed October 2003.

${ }^{\mathrm{h}}$ http://bioenergy.ornl.gov/resourcedata/index.html, Biomass Feedstock Availability in the United States: 1999 State Level Analysis, accessed Oct. 2003. 


\section{Appendix C References}

EIA: Energy Information Administration.

EIA, 2001, Annual Coal Report 2001, DOE/EIA-0584, Washington, D.C.

EIA, 2002, U.S. Crude Oil, Natural Gas and Natural Gas Liquids Reserves, 2001 Annual Report, DOE/EIA-0216 (2001), Washington, D.C., Nov.

EIA, 2003, Annual Energy Outlook 2003, with Projections to 2025, DOE/EIA-0383 and Appendices, Washington, D.C., Jan.

Patterson, P., et al., 2003, "Joint DOE/NRCAN Study of North American Transportation Energy Futures: Discussion of the Study, Presentation of Phase 2 Results (May 2003)," presented to U.S. Department of Energy, Washington, D.C., April 17.

R.S. Means Construction Cost Estimating Guide, 2002, Kingston, Mass.

SFA Pacific, Inc., 2002, Hydrogen Supply: Cost Estimate for Hydrogen Pathways-Scoping Analysis, NREL/SR-540-32525, National Renewable Energy Laboratory, Golden, Colo., July.

Singh, M., A. Vyas, and E. Steiner, 2003, VISION Model: Description of Model Used to Estimate the Impact of Highway Vehicle Technologies and Fuels on Energy Use and Carbon Emissions to 2050, ANL/ESD/04-1, Argonne National Laboratory, Argonne, Ill., Dec.

U.S. Census Bureau, 2000, 1997 Economic Census: Retail Trade Geographic Series, EC97R44A-US(RV) (also see individual state reports), Washington, D.C., March, available at http://www.census.gov/prod/ec97/97r44-us.pdf 
